Florida International University FIU Digital Commons

\title{
Characterization of Rhizobial Diversity and Relationship of Rhizobial Partner and Legume Performance in Four South Florida Pine Rockland Soils
}

Vanessa Sánchez

Florida International University, vanessa.sanchez.velez@gmail.com

DOI: $10.25148 /$ etd.FI14040823

Follow this and additional works at: https://digitalcommons.fiu.edu/etd

Part of the Environmental Microbiology and Microbial Ecology Commons, Genetics Commons, Molecular Genetics Commons, Natural Resources and Conservation Commons, and the Population Biology Commons

\section{Recommended Citation}

Sánchez, Vanessa, "Characterization of Rhizobial Diversity and Relationship of Rhizobial Partner and Legume Performance in Four South Florida Pine Rockland Soils" (2014). FIU Electronic Theses and Dissertations. 1124.

https://digitalcommons.fiu.edu/etd/1124 


\title{
FLORIDA INTERNATIONAL UNIVERSITY \\ Miami, Florida
}

\section{CHARACTERIZATION OF RHIZOBIAL DIVERSITY AND RELATIONSHIP OF RHIZOBIAL PARTNER AND LEGUME PERFORMANCE IN FOUR SOUTH FLORIDA PINE ROCKLAND SOILS}

\author{
A thesis submitted in partial fulfillment of the \\ requirements for the degree of \\ MASTER OF SCIENCE \\ in \\ ENVIRONMENTAL STUDIES \\ by
}

Vanessa Sánchez 
To: Dean Kenneth G. Furton

College of Arts and Sciences

This thesis, written by Vanessa Sánchez, and entitled Characterization of Rhizobial Diversity and Relationship of Rhizobial Partner and Legume Performance in Four South Florida Pine Rockland Soils, having been approved in respect to style and intellectual content, is referred to you for judgment.

We have read this thesis and recommend that it be approved.

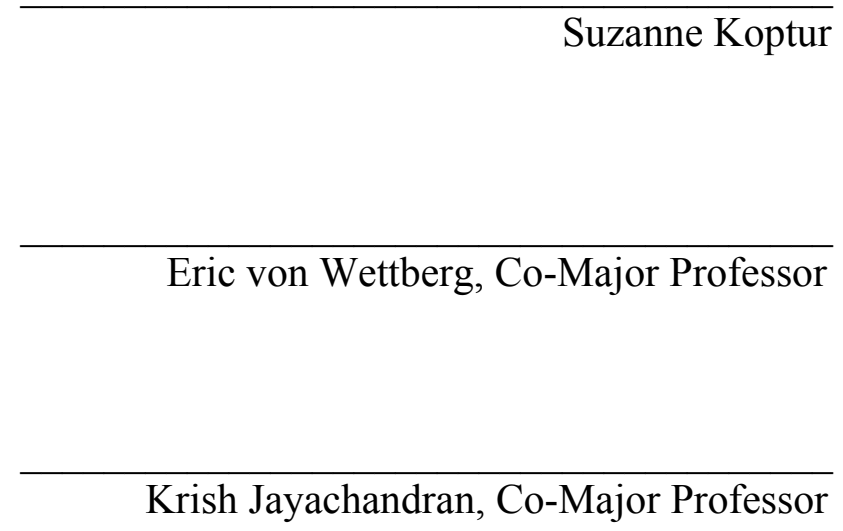

Date of Defense: March 28, 2014

The thesis of Vanessa Sánchez is approved.

$\begin{array}{r}\begin{array}{r}\text { Dean Kenneth G. Furton } \\ \text { College of Arts and Sciences }\end{array} \\ \hline \begin{array}{r}\text { Dean Lakshmi N. Reddi } \\ \text { University Graduate School }\end{array}\end{array}$

Florida International University, 2014 


\section{DEDICATION}

To all those who encouraged and inspired me. 


\section{ACKNOWLEDGMENTS}

I would like to express my deepest appreciation to the members of my committee, Drs. Eric von Wettberg, Krish Jayachandran, and Suzanne Koptur for their guidance, assistance, patience, and support.

Special thanks to my mother and sister for always believing in me, and offering their unconditional love, support, and motivation. To my father, that from heaven always looks after me.

The success and final outcome of this project required a lot guidance and assistance from many people. I wish to acknowledge the members at the von Wettberg lab: Klara Scharnagl, Emily Warschefsky, Damian Nesbeth, Yadira Reynaldo and Daniella Vargas for their assistance with the experimental design and data collection. Many thanks to my Agroecology fellows for their constant support and motivation, to Fairchild Tropical Botanical Garden, and their Graduate Student Program for providing essential tools to conduct my research. Dr. Paul Sharp (FIU DNA Core Lab), members from Dr. Varshney's laboratory at ICRISAT (Hyderabad, India), and Dr. Cook's laboratory at the University of California (Davis, USA), for their technical support.

There are many people without whom this thesis might not have been written, and to whom I will be forever grateful, Dr. Dayana Salas-Leiva, Beyte Barrios, Nina De La Rosa, Audrey Becnel, Dr. Pushpa Soti, and Stephany Alvarez-Ventura.

Finally, I would like to thank the United States Department of Agriculture National Needs Fellowship 2011-38420-20053, for providing the funding for my research assistantship and this project. 


\begin{abstract}
OF THE THESIS
CHARACTERIZATION OF RHIZOBIAL DIVERSITY AND RELATIONSHIP OF

RHIZOBIAL PARTNER AND LEGUME PERFORMANCE IN FOUR SOUTH

FLORIDA PINE ROCKLAND SOILS
\end{abstract}

by

Vanessa Sánchez

Florida International University, 2014

Miami, Florida

Professor Krish Jayachandran, Co-Major Professor

Professor Eric von Wettberg, Co-Major Professor

Pine rocklands are endangered ecosystems unique to south Florida, the Bahamas and Cuba. As a result of their karstic calcium carbonate-rich soils, these systems are limited in phosphorus and nitrogen, making symbiotic associations critical to plant growth. Four leguminous species (Cajanus cajan, Chamaecrista fasciculata, Tephrosia angustissima, and Abrus precatorious) were used to determine the relationship between rhizobial partners and plant performance, and the symbiosis related gene nifH was amplified to characterize the diversity of rhizobial symbionts. Plants were grown in soils from four different south Florida pine rocklands, and a salinity treatment was added to determine how storm surge and sea level rise could affect this symbiotic relationship. While plant performance and nodulation were highly impacted by soil type, salinity did not represent a significant effect. Phylogenetic analysis determined that all four plant species were found to associate with Bradyrhizobium spp. and no rhizobial shift between salinity treatment and soil type was found. 


\section{TABLE OF CONTENTS}

CHAPTER

PAGE

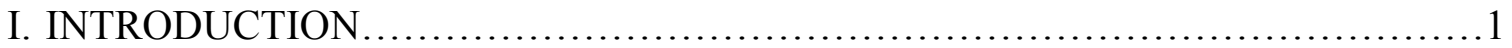

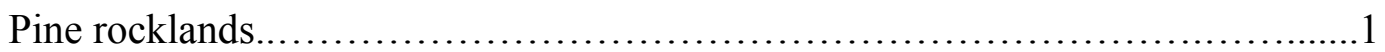

Legumes and their ecological role..........................................

Rhizobia and nodule formation.............................................

Importance of nitrogen fixation............................................. 8

Legume-rhizobium symbiosis............................................ 10

II. OBJECTIVES AND PROPOSED REASEARCH .................................11

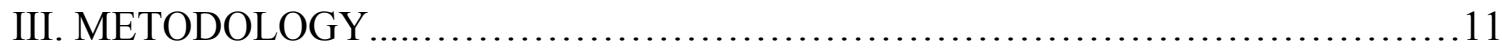

Pine rockland soil collection ............................................... 12

Experimental design..................................................... 14

Plant monitoring and harvest............................................. 17

Plant fitness measures. ................................................. 19

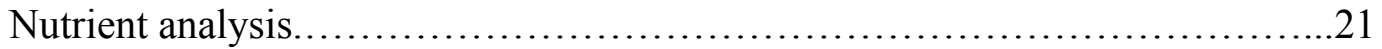

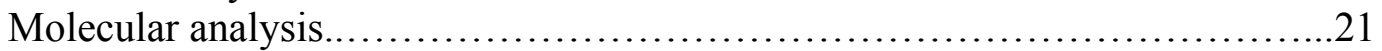

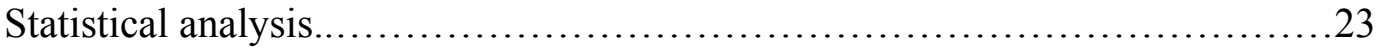

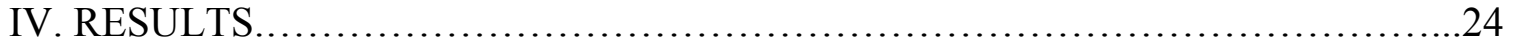

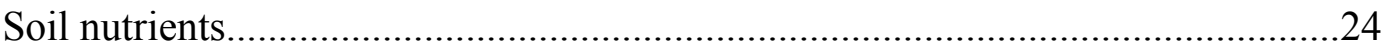

Effects of soil type and salinity treatment in nodulation.......................................25

Effects of salinity treatment, soil source, and their interaction..................27

Relationship between plant performance and nodulation........................27

Phylogenetic analysis........................................................

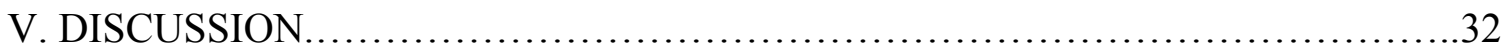

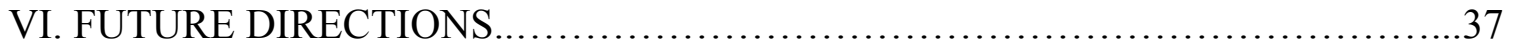

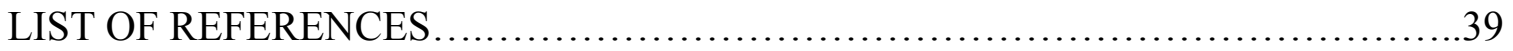

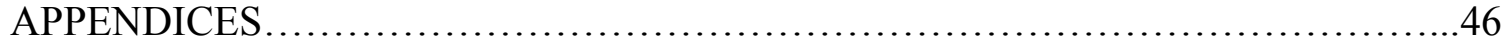




\section{LIST OF TABLES}

TABLE

PAGE

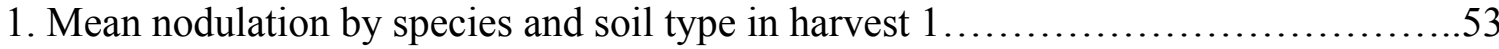

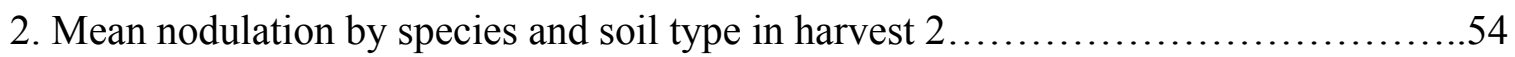

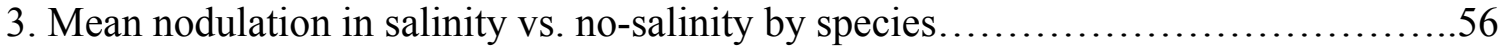

4. Analysis of variance with salt treatment, soil, and salt $\mathrm{x}$ soil as predictor variables....57

5. Correlation among plant performance measurements and nodulation by plant host

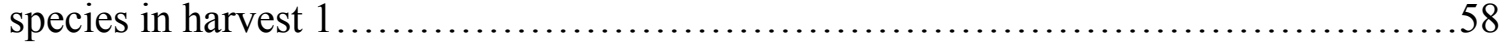

6. Correlation among plant performance measurements and nodulation by plant host

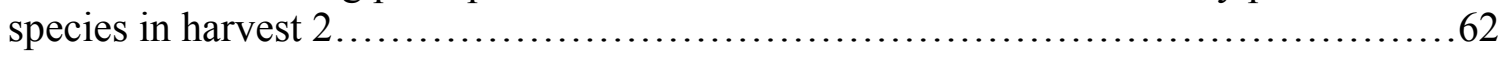




\section{LIST OF FIGURES}

FIGURE

PAGE

1. South Florida pine rockland sampling sites................................... 46

2. Soil nutrient composition of pine rockland sites.............................47

3. Dry shoot and root biomass by host species.................................. 48

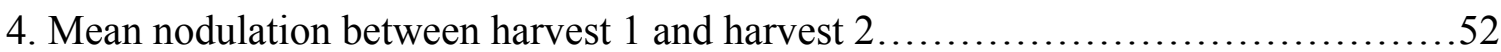

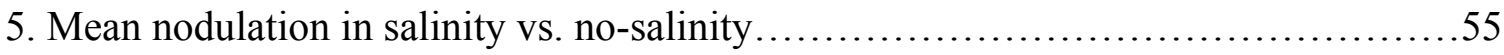

6. Maximum likelihood phylogenetic tree by host species.........................66

7. Maximum likelihood phylogenetic tree by salinity treatment....................67

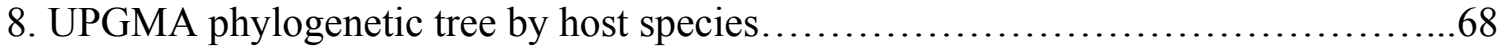

9. UPGMA phylogenetic tree by salinity treatment.............................69 


\section{ABBREVIATIONS AND ACRONYMS}

\begin{tabular}{|c|c|}
\hline ANOVA & Analysis of Variance \\
\hline AMF & Arbuscular Mycorrhizal Fungi \\
\hline BLAST & Basic Local Alignment Search Tool \\
\hline BPK & Big Pine Key \\
\hline СТРC & Center for Tropical Plant Conservation \\
\hline DSW & Dry Shoot Weight \\
\hline DRW & Dry Root Weight \\
\hline EEL & Environmentally Endangered Lands Program \\
\hline FIU & Florida International University \\
\hline MMC & Modesto Maidique Campus \\
\hline $\mathrm{N}$ & Nitrogen \\
\hline $\mathrm{N}_{2}$ & Atmospheric Nitrogen \\
\hline NCBI & National Center for Biotechnology Information \\
\hline $\mathrm{P}$ & Phosphorus \\
\hline PCR & Polymerase Chain Reaction \\
\hline TREC & Tropical Research and Education Center \\
\hline UPGMA & Unweighted Pair Group Method with Arithmetic Mean \\
\hline
\end{tabular}




\section{INTRODUCTION}

\section{I-A. Pine rocklands}

Pine rocklands are designated globally endangered ecosystems unique to south Florida, the Bahamas and Cuba. They are savanna-like forests whose flora is influenced by its proximity to the tropics, and also to its peninsular connection to mainland Florida. These periled ecosystems contain the highest plant diversity of any other ecosystem in Florida, and serve as home to over 350 native plants, some of which are among Florida's endemic species (Department of Environmental Resource Management, 1993). Plants like the Deltoid Spurge (Chamaesyce deltoidea), Blodget's Wild Mercury (Argythamnia blodgettii), Small Milkpea (Galactia smallii), and the Rockland Lantana (Lantana depressa) are some of the species found in south Florida's pine rocklands and nowhere else in the world (U.S. Fish and Wildlife Service, 1999).

In south Florida, pine rockland ecosystems can be found in three main geographic locations. On limestone substrates on the Miami Rock Ridge, which have the largest remaining area within the Everglades National Park; in the Florida Keys, mostly within the National Key Deer Refuge; and in the Big Cypress Swamp, entirely within Big Cypress National Preserve (Snyder et al., 2005). Pine rocklands in the Miami Rock Ridge contain most of the State listed plant taxa with $88 \%$, while the Florida Keys contain 49 \%, and Big Cypress only 17 \% (U.S. Fish and Wildlife Service, 1999). They consist of a single dominant overstory species commonly known as the South Florida Slash Pine (Pinus elliottii var. densa), with a rich understory layer mostly comprised of tropical palms and hardwood species, and a groundcover with a wide diversity of herbaceous 
species, grasses and shrubs (Dade County Park and Recreation Department, 1993; O’Brien, 1998).

Overall, there are more than fifty plant species considered by the State to be endangered or threatened (Miami-Dade County Code, 2005). Currently there are five pine rockland species listed as federally endangered: Garber's Spurge (Chamaesyce garberi), Deltoid Spurge (Chamaesyce deltoidea), Tiny Polygala (Polygala smallii), Small's Milkpea (Galactia smallii) and Crenulate Lead-Plant (Amorpha crenulata) (U.S. Fish and Wildlife Service, 1999). There are several endemic pine rockland plant species that are now thought to be extinct such as the Narrow-Leaved Hoary-Pea (Tephrosia angustissima), Mrs. Britton's Shadow-Witch Orchid (Ponthieva brittoniae), and the Bahama Manjack (Cordia bahamensis) (U.S. Fish and Wildlife Service, 1999). As species become extinct, so does the evolutionary capacity of its ecosystem, as well as their critical functions like nitrogen fixation, pollination among others that may no longer be provided to maintain equilibrium, and many other ecosystem services. Furthermore, as their genetic diversity within species is eroded, their capacity to adapt to changing environmental conditions is diminished, and they may be pushed into an extinction vortex (Gilpin and Soulé, 1986). Pine rocklands are a great source of food, shelter, and nesting for a significant number of wildlife species. There are fifteen species of vertebrates that are endemic to south Florida pine rocklands (Snyder et al., 1990), from which ten are mammals and five are reptiles. Species like the Florida Atala butterfly, Big Pine Key Ringneck Snake, Big Cypress Fox Squirrel, Key Deer, and the Key Mud Turtle, are amongst the species needing immediate conservation efforts (Snyder, 1990; Maschinski et al., 2011). 
Pine rocklands are highly dependent on periodic fire burns (Snyder et al., 1990). They need to be burned at least once every 10 years in order to maintain their optimal ecosystem health (Snyder et al., 1990) by eliminating invading hardwoods, promoting flowering of herbaceous species, fruit production of woody species, and assisting in the process of nutrient cycling. Scientists have documented that fire suppression can cause the succession of pine rocklands into tropical hardwood hammocks in a period of 20 to 30 years (Alexander, 1967; Wade et al., 1980; Loope and Dunevitz, 1981; Snyder et al., 1990). Many former pine rockland properties have transitioned to hardwood hammocks or have become invaded by non-native species (Koptur, 2006), which has caused a net loss of biodiversity and the extinction or near extinction of several native plant species. Given these unfavorable conditions, and knowing that pine rocklands are currently reduced to less than $2 \%$ of their original area, management practices like prescribed fires and the acquisition of surrounding lands in order to form biological corridors could represent significant benefits to these globally endangered ecosystem.

Other threats specific to pine rocklands include: fragmentation, conversion to commercial and industrial development, housing and urban development, invasive animals and plants, chemicals, toxins, reduction in the mean water table, and sea level rise. (Department of Environmental Resource Management, 1993; U.S. Fish and Wildlife Service, 1999; Ross et al., 1994). Fragmentation in particular is of great concern to pine rocklands because the artificial separation from other communities imposes serious negative effects on both the habitat and the wildlife that make use of them (U.S. Fish and Wildlife Service, 1999). Fragmentation reduces habitat size, causes genetic isolation of the different populations, decreases pollination, creates barriers in seed dispersal, and 
increases an edge effect by causing insect infestation, diseases, and establishment of invasive species. Anthropogenic activities further affect these areas by polluting the air, reducing insect diversity trough mosquito control and other chemical applications, increasing erosion through development, dumping trash and construction debris (Alonso and Heinen, 2011).

Prior to settlement, pine rocklands constituted over 185,000 acres in south Florida, but as of 1990 only about 4,400 acres remained (Miami-Dade County Code, 2005). The accelerated urban sprawl and population growth of Miami-Dade County has resulted in a severe reduction of pine rockland habitats. Land clearing for development and agricultural practices began during the late 1800 's, and continued unabated until the year 1984, when Miami-Dade County approved the Tree Protection Ordinance in order to provide some form of protection to upland forests. In 1996, when the city of Miami celebrated its 100 th anniversary, it was estimated that only about $2 \%$ of the original pine forests remained (Department of Environmental Resource Management, 1993; Noss and Peters, 1995). The Miami-Dade County Environmentally Endangered Lands Program (EEL), describes that the remaining pineland fragments seem scattered across the industrial, residential, and agricultural areas, "looking less like a forest and more like an island of trees in a sea of urbanization".

Symbiotic associations are known to improve plants ability to uptake nutrients since mutualists can alter plant functional traits, and therefore mediate ecological, evolutionary and ecosystem processes (Friesen et al., 2011). By conducting research on integrating systematics, population genetics, and functional approaches to understand legume-symbiont biodiversity in a threatened community like pine rocklands, we could 
uncover the aspects of biodiversity necessary to better understand microbial diversity in soils. Therefore, characterizing symbiotic microbial diversity, the degree in which they improve soil-plant-microbial interactions, their preferred host species and plant community structure, will be critical to understand the role of these symbionts in natural populations, and thus provide tools to develop improved management and conservation practices for south Florida pine rocklands.

\section{I-B. Legumes and their ecological role}

Legumes are the third-largest family of flowering plants (Doyle and Luckow, 2003), evolving about 60 million years ago (Sprent, 2007). They can be found in all areas of the world except for open seas (Sprent, 2009), ranging from rain forests to deserts, and from lowlands to alpine pine habitats (Doyle and Luckow, 2003). The leguminous family contains several horticultural varieties and many species that can be harvested as crops, or that can be used for oils, fiber, fuel, timber, medicines, and chemicals. Grain legumes are an important source of protein, essential vitamins, and minerals. According to the Cereal Knowledge Bank (2009), species like Pigeon Pea (Cajanus cajan), Soybean (Glycine max), Chickpea (Cicer arietinum), and Mungbean (Vigna radiata), have protein contents ranging from $17-40 \%$, which represent a main nutritional source for many developing countries. They are divided in three sub-families: Caesalpinioideae, Mimosoideae, and Papilionoideae.

Leguminous plants play an important role in agricultural systems since they can be incorporated as green manure, a general term that refers to the process of using plants to enhance soil fertility. The process of green manuring with legumes involves growing the plants, slashing them and leaving them on the soil surface. This practice has 
additional benefits like controlling soil erosion and maintaining soil moisture (Sullivan, 2003). Another agricultural practice for the use of leguminous plants is intercropping. This practice includes growing other crops like maize and squash that could benefit from the additional nitrogen supply provided by legumes. A crop rotation system with cereals is another common practice. This system is intended to provide the farmer with an additional harvest while at the same time improving the soil fertility.

Legumes are widely distributed within pine rocklands. Some important members of the pine rockland legume community are species of the genera Caesalpinia, Chamaecrista, Pithecellobium, and Rhynchosia (Gann et al., 2014). These species can form a symbiotic relationship with both arbuscular mycorrhizal fungi (AMF) that can scavenge and mobilize phosphorus $(\mathrm{P})$ more effectively from the soil than plant roots by themselves, and with rhizobial bacteria capable of converting atmospheric nitrogen $\left(\mathrm{N}_{2}\right)$ into ammonium $\left(\mathrm{NH}_{4}\right)$, a process better know as nitrogen fixation. This important association plays a major agricultural and ecological role by contributing much greater rates of fixed nitrogen than any other free-living fixing organisms (Sprent, Sutherland and de Faria, 1987). Heterotrophic free-living $\mathrm{N}_{2}$ fixers that utilize plant residues like straw and leaf litter, contribute approximately $5 \mathrm{~kg} \mathrm{~N} /$ ha per year (Unkovich et al., 2008). Cyanobacteria and photosynthetic bacteria present in wetlands and soil surface of rice paddy fields can supply as much as $30 \mathrm{~kg} \mathrm{~N} / \mathrm{ha}$ per year (Firth et al., 1973), while the mutualistic relationship between legumes and rhizobia supplies in the range of 200-300 $\mathrm{kg} \mathrm{N} / \mathrm{ha}$ per year (Peoples et al., 1995) making legumes responsible for the largest contribution of fixed nitrogen to farming systems. 
As a result of their karstic calcium carbonate-rich soil, pine rockland systems are limited in phosphorus and nitrogen, making symbiotic soil mutualisms critical to plant growth and productivity. Therefore, effective mutualists are essential for the growth and competitive ability of host plants. While associations with rhizobial bacteria are specific to legumes, most plants, including but not limited to legumes, also associate with arbuscular mycorrhizal fungi (Bonfante and Genre, 2010). Both of these associations have important consequences directly on the nutrition of these plants, as well as on the plants growing nearby.

Given the low levels of nitrogen and phosphorus in pine rocklands soils, microorganisms associated with legumes can be of particular importance for facilitating the growth of other pine rockland plant species. Symbionts like the soil bacteria rhizobia and mycorrhizal fungi, can significantly promote fitness advantages by increasing nutrient availability for their host plant. According to Vitousek and Walker (1989), the incidence of effective mutualists enhances the growth and competitive ability of their host plants, which can also influence ecological succession, plant productivity, and community restoration. Furthermore, it is believed that some of the phenotypical characteristics in plants can arise as a result not only from the genetic plant information itself, but also from the interaction between the plant and its microbial symbionts (Friesen et al., 2011).

\section{I-C. Rhizobia and nodule formation}

Rhizobia are rod-shaped, gram-negative bacteria living in soils where they are able to sense flavonoids secreted by the roots of their leguminous host, which trigger the expression of the rhizobial genes, required for nodulation (Sprent, 2009). A complex 
interaction between host root, rhizobia, and the environment are involved in the formation of nodules in the legume-rhizobium symbiosis. Several rhizobia are intimately associated with different partners having a wide-range host (promiscuous bacteria), while others are more selective and specific, thus having a more narrow host range (Perret et al., 2000; Tan et al., 1999), and so far only the symbionts from a limited number of legumes has been thoroughly investigated (Young and Haukka, 1996).

The specificity of the legume-rhizobium symbiotic interaction is largely determined by the recognition of signal molecules produced by both the bacteria and the plant host. Rhizobia can recognize their compatible host when specific flavonoid molecules are released either from the seed or the roots of legumes (Sprent, 2009). This recognition event triggers gene transcription in the bacterium leading to the expression of nodulation genes commonly know as Nod factors. In turn, the nodulation genes encode enzymes that synthesize a very special signal molecule, called a lipo-chitooligosaccharide (Sprent, 2009). The nodulation signal is emitted and then recognized by the plant through specific receptors. A well-studied method of infection is the curling of root hairs to form a pocket in which the bacteria can enter the cortex cells by forming an infection thread that will grow down through the root hair, where it eventually enters and ramifies. The fast division of cortical cells results in the formation of a structure known as the nodule (Sprent, 2009).

\section{I-D. Importance of nitrogen fixation}

Though dinitrogen $\left(\mathrm{N}_{2}\right)$ gas represents $78 \%$ of the earth's atmosphere, it is not readily available to plants (Unkovich et al., 2008). Biological nitrogen fixation is the process of converting atmospheric nitrogen in the presence of a bacteria that uses the 
enzyme nitrogenase, into ammonia, a form of nitrogen that can then be incorporated into organic components like proteins and nucleic acids, of the bacteria and the associated plants (Unkovich et al., 2008). During this process, unreactive $\mathrm{N}_{2}$ enters the biologically active part of the global nitrogen cycle. Next to photosynthetic processes, nitrogen fixation is probably the most important biologically mediated process on earth. There is a wide diversity of nitrogen-fixing organisms, known as diazotrophs. Some can fix nitrogen in their free-living state like Azotobacter and Azospirillum while others fix nitrogen only in association with plants.

The atmosphere contains about $10^{15}$ tonnes of nitrogen gas. The nitrogen cycle involves the conversion of some $3 \times 10^{9}$ tonnes of nitrogen per year on a global basis by different mechanisms (Postage, 1982). The process of nitrogen fixation by lighting accounts for about 10\% of the world's fixed nitrogen supply (Sprent and Sprent, 1990).

The nitrogen provided by the fertilizer industry provides much larger quantities of fixed nitrogen. It has been estimated that the world production of fixed nitrogen from dinitrogen $\left(\mathrm{N}_{2}\right)$ for chemical fertilizer accounts for about $25 \%$ of the Earth's newly fixed $\mathrm{N}_{2}$, while biological nitrogen fixing processes account for about $60 \%$ (Zahran, 1999). As the global demand for food has increased, so has the global consumption of nitrogen fertilizers in both developed and developing countries (Peoples et al., 1995). However, in the Unites States and in other developed countries, the cultivation of $\mathrm{N}$ fixing crops has decreased while there has been an increased use of industrial fertilizers. To meet those demands, close to 100 million tonnes of nitrogen are fixed annually via the industrial Haber Bosch process (Peoples et al., 2005), which requires large inputs of energy usually in the form of natural gas. Nitrogen fertilizer requirements are estimated to continue 
increasing (Subba-Rao, 1980). Nonetheless, given the current available technologies for fertilizer production and the inefficient techniques utilized by industrialized agriculture systems, both the economic and ecological costs of fertilizer usage will eventually become excessive. Therefore the importance of advocating biological nitrogen fixation as a nonpolluting and more cost effective way to improve soil fertility when compared to other nitrogen fixating alternatives.

Nitrogen fixation by leguminous plants is of great importance in less industrialized countries where nitrogen fertilizers are not used (Zahran, 1999) and because it is required to biosynthesize the basic building blocks of life, like nucleotides for DNA and RNA, and amino acids for protein formation.

\section{I-E. Legume-rhizobium symbiosis}

The interaction of plants and pathogens or soil microorganisms like rhizobia is an important trait that has recently been studied as part of the domestication syndrome (Gepts, 2004). Several studies conducted on these interactions suggest that both host and microorganism have undergone a reciprocal selection process leading to co-evolution and the adaptation of both organisms (Gonzalez-Rodriguez et al., 2000). A good example of such interactions is the one occurring between legumes and the soil bacteria rhizobia, which requires a very a highly complex series of interactions between the plant and the bacterium, resulting in the process of nitrogen fixation. Nitrogen is the most commonly deficient plant nutrient in soils around the world, limiting the productivity of most ecosystems, and therefore representing a challenge in modern agriculture.

The interaction between plants and symbiotic soil microorganisms are important indicators of ecosystem productivity and diversity (Thrall et al., 2011). Mutualistic 
symbionts play an important ecological role in governing the cycles of major plant nutrients like nitrogen and phosphorus, and thus assist in sustaining the vegetation cover in natural habitats (Requena et al., 2001).

Legume-rhizobium interactions have not been studied in pine rocklands, and therefore the diversity of rhizobia across the remaining forest patches is unknown. Greater understanding of the diversity of rhizobia across soils and salinity conditions can lead to a better understanding of how rhizobia can assist legumes with stress tolerance, especially when being exposed to high salinity levels, as in the case of the remaining pine rockland patches in the Florida Keys.

\section{OBJECTIVES AND PROPOSED RESEARCH}

The main objective of this experiment was to characterize the diversity of rhizobial symbionts present in legumes growing on four different south Florida pine rockland soils, and to determine the relationship between plant performance, as measured by above ground biomass, aboveground nitrogen content, and nodulation. The second objective was to determine how a salt treatment that mimics the effects of storm surge and sea level rise modifies legume-rhizobium symbiotic relationships. The first aim will inform subsequent efforts I have begun to use next generation molecular techniques to sequence housekeeping and symbiosis related genes.

\section{METHODOLOGY}

In order to determine the relationship of rhizobial symbionts, legume performance and fitness, a randomized shade-house experiment consisting of three replicates, was 
carried out at the Center for Tropical Plant Conservation (CTPC), using pine rockland soils collected from four different locations in south Florida (Fairchild Tropical Botanic Garden, Coral Gables; Florida International University/Modesto Maidique Campus Nature Preserve, Miami; Tropical Research and Education Center-University of Florida, Homestead and Big Pine Key, Florida Keys), in addition to a control using autoclaved soils. Four leguminous species (Cajanus cajan, Tephrosia angustissima, Chamaecrista fasciculata, and Abrus precatorious) were selected as host plants to trap rhizobia and arbuscular mycorrhizal fungi from different pine rockland soils that were either treated with saline water $(100 \mathrm{mM} \mathrm{NaCl})$ simulating sea level rise concentrations or distilled water.

\section{III-A. Pine rockland soil collection}

Soils for this study were collected from four pine rockland sites in south Florida including one site in the Florida Keys (Figure 1). The soil layer in these sites was limited because of their underlying limestone substrate and therefore, tools like a shovel and a pickaxe were required. The collected soils were stored in five gallon buckets, covered with aluminum foil, and stored inside the garden house at the Center for Tropical Plant Conservation. Even though the soils were at rest for six months before the actual shade house experiment was started, they maintained some of its natural moisture and only a few pests were observed. This could represent a limitation for capturing the full rhizobial diversity present at these sites, but it does not represent a barrier to assessing the relationship of the available symbionts with their leguminous hosts, since rhizobia are able to form dormant forms, they would still be present for nodule formation in this experiment. Large rocks and pieces of debris were manually removed from the collected 
soils, but since they were not sieved, many small rocks remained at their natural stage and were incorporated into the conical pots used in the experiment. The presence of these small limestone rocks helped to mimic natural pine rockland growing conditions.

Given the extensive limestone bedrock in pine rocklands, soils had to be collected from several areas within each site where soil was available. This sampling method allowed to have a better survey of soil microorganisms, and also helped to reduce the levels of disturbance in the sampled sites. From the four pine rocklands selected, none are known to have a prescribed fire regime, and therefore fire is not considered as one of the factors in this study. The soil used as a control was a composite mix of the four sites, and this control soil was sterilized by autoclaving two times with a 24 hours interval between each autoclave cycle.

The first collection site was a small pine rockland patch located at the Center for Tropical Plant Conservation (CTPC) in Coral Gables. This site is in the process of transitioning to a hardwood hammock ecosystem as a result of the lack of a fire regime, and other abiotic factors that are needed to maintain its original pine rockland status. The next set of soil was collected from the Nature Preserve located at Florida International University (FIU- MMC). This small pine rockland is surrounded by a much larger hardwood hammock ecosystem. It is an intact pine rockland without prescribed fire, however, a restoration project was taking place at the Nature Preserve while sampling for this project, where new soil was incorporated into the area, and thus, some of the collected soils might not have been there for a very prolonged period of time. The most pristine pine rockland collection site was located at the University of Florida (UF) Tropical Research and Education Center (TREC) in Homestead. The collected soils had a 
red coloration, typical of the Redlands in south Florida, exhibit high contents of clay and having good soil aggregates. The fourth collection site was a coastal pine rockland in Big Pine Key, located in the Florida Keys. It was not possible to obtain a collection permit to access the pine rockland areas within the National Wildlife Refuge and therefore, sampling had to occur on an adjacent pine rockland located on a private property. This site was the most challenging to collect soils from because of its thin layer of soil, making the use of a pickaxe necessary to extract sufficient material from the limestone. One of the leguminous species selected for this study, Chamaecrista fasciculata was found to be extensively growing on this property.

\section{III-B. Experimental design}

The selected experimental design was a randomized experiment consisting of three replicates that were carried out in a shade-house at the Center for Tropical Plant Conservation (CTPC), Fairchild Tropical Botanic Garden. The experiment was set up in late May of 2012. In Florida, this represents the beginning of the rainy season; therefore to avoid flooding, to allow for proper draining, and to reduce pests and diseases, the pots were set in special cone-tainer trays, which helped to elevate them according to their pot size. This setup was then placed on two tables inside the shade-house. Three different plastic cone-tainer sizes were used for this experiment, small $\left(49.0 \mathrm{~cm}^{3}\right)$, medium $(106.5$ $\left.\mathrm{cm}^{3}\right)$, and large $\left(163.8 \mathrm{~cm}^{3}\right)$. These specialized cone-shaped planting pots allowed for maximum root growth, and simplify plant harvesting. This shade-house experiment was shared with former graduate student Klara Scharnagl who studied the percent colonization of arbuscular mycorrhizal fungi (AMF's). Thus the importance of having three pot sizes, in order to maximize the capture of microbial symbionts by giving the 
less competitive species the chance to infect the roots of their hosts when present in smaller areas (Audet, 2010). For the specific objectives of my thesis, only the plants growing on large cone-tainers were selected for further molecular and statistical analysis.

Four leguminous species were selected as host species to trap microbial symbionts. One seed per cone-tainer was placed approximately $2 \mathrm{~cm}$ below the surface of the soil. Half of the plants were treated with saline water $(100 \mathrm{mM} \mathrm{NaCl})$ to determine how increased salinity affects the legume-rhizobium symbiotic relationship. The other half received a distilled water treatment. The experiment was divided into two harvests, an early pre-flowering harvest in July 29,2012, and a later post-flowering harvest in August 1, 2012. It is known that as some plants mature, they can have the ability of forming a symbiotic relationship with different microbial communities, which changes according to the plants life cycle (Scharnagl, 2013). Once the plant starts to flower nodules senesce. The plant stops investing in the nodules so that it can pull the resources out of the roots and into its pods (Salter and Drew, 1965).

The total number of plants harvested from large cone-tainers was 168, which will be the focus of my thesis research. The plant hosts selected for this experiment were Cajanus cajan (a crop legume), Tephrosia angustissima (state endangered), Chamaecrista fasciculata (native to south Florida), and Abrus precatorious (exotic and invasive in Florida).

Cajanus cajan commonly known as Pigeon Pea, is a crop legume having a long history of cultivation (Sprent, 2009), that belongs to the largest and most complex of the three legume sub-families; Papilioniodeae. Even though it is not commonly grown in south Florida for commercial purposes, it is one of the main grain legume crops gown in 
semiarid regions of the world (Varshney et al., 2012). It is a short-lived perennial, often grown as an annual, consisting of a deep root system that allows the plant to access nutrients including poorly available soil phosphorus (Sprent, 1999). Pigeon Pea is an excellent protein source, and its leaves and tops can be used as fodder and green manure as soil amendments (Ambasta, 2004).

Chamaecrista fasciculata, commonly known as Partridge Pea is the dominant Chamaecrista species in south Florida but can be found throughout the eastern United States. It is an annual small herb, under the Caesalpinioideae legume sub-family, known to have the smallest proportion of nodulating species among the three main legume groups (Caesalpinioideae, Mimosoideae, and Papilionoideae) (Allen and Allen, 1981), with less than $25 \%$ of Caesalpinioids known to nodulate (Hirsh et al., 2001). Currently, there is undergoing efforts to understand nodulation and other characteristics of Chamaecrista fasciculata, as a model legume for Caesalpinioids (Sprent, 2009; Singer et al., 2010). A better understanding of nodulation patterns and genomics of this native legume could have significant impacts in the restoration and conservations of pine rocklands.

Tephrosia angustissima commonly known as Narrow-Leaved Hoary Pea is a state-listed endangered legume that belongs to the Papilionoideae legume sub-family. As a result of the loss of pine rockland habitats and the invasion of exotic plants, it has been estimated that this species has significantly declined by $50-70 \%$ in the past ten years (IUCN Red List, 2012). Studies by Fisher and Jayachandran (personal communication) with native AMF's have shown that this association has positive effects by promoting dry weight and nodule number on this species. 
The fourth legume species selected for this experiment was Abrus precatorious, also known as Crab's Eye Vetch or Rosary Pea that belongs to the Papilionoideae legume sub-family. This high-climbing leguminous vine is considered an invasive exotic species and it is widely found in south Florida pine rocklands.

Each collected pine rockland soil was assigned a number to generate a labeling system for every plant; FIU (soil 1), CTPC (soil 2), BPK (soil 3), TREC (soil 4) and Control (soil 5). In order to fill each cone-tainer, volunteers used plastic gloves, and were assigned to a specific soil type to avoid cross contamination. A piece of nylon mesh of approximately $4 \times 4$ inches was placed at the bottom of each cone-tainer to hold the soil in place, and soil was added up to $3-5 \mathrm{~cm}$ before reaching the top of the cone-tainer. Once the soils were added to each cone-tainer, they were arranged by soil type on the tables, and one legume seed also having an assigned number (Cajanus cajan (2), Chamaecrista fasciculata (3), Tephrosia angustissima (4), or Abrus precatorious (5)), was planted 2-4 $\mathrm{cm}$ deep into the soil and covered.

\section{III-C. Plant monitoring and harvests}

The experiment was monitored every other day after seeds were planted. Once plant emergence was observed, seedling height was recorded once a week in centimeters, by placing a measuring tape at soil level and measuring all the way to the topmost part of each plant. All plants were constantly monitored for pests and weeds, and in case these were found they were manually removed. After three weeks of plant growth, a Hoagland's solution without nitrogen $(\mathrm{N})$ and phosphorus $(\mathrm{P})$ was supplemented on a weekly basis. Using a dropper, $1 \mathrm{~mL}$ of the Hoagland's solution was added to each container, and dispersed around the base of each plant. Similarly after three weeks of 
growth, a $100 \mathrm{mM} \mathrm{NaCl}$ saline solution was added to those plants receiving a saline treatment. Using a dropper, $1 \mathrm{~mL}$ of saline solution was added to each plant receiving a salinity treatment. The two solutions were never applied at the same time. Heavy herbivory was observed after four weeks of planting. Snails and other pests were spotted feeding from leaves, especially from Cajanus cajan, which had the biggest surface area. Thus a one-time application of "Snail Bait" was added to the plants affected by herbivory, and whenever snails were spotted after this treatment was applied, they were manually removed.

This shade-house experiment was carried out during a period of four months, between May and August 2012. During this time there were heavy frequent rains and thunderstorms, with average temperatures of $27^{\circ} \mathrm{C}$. Subsequent to the first harvest, all plants remaining for the second harvest had to be brought inside the main CTPC building during a tropical storm. They remained indoors for a period of 48 hours, and were returned to the shade-house, were they continued to develop until the second harvest took place.

The first harvest took place after eight weeks of plant growth, when plants on both tables were observed to be robust, but had not yet started to flower. The second harvest was scheduled after twelve weeks of plant growth, when flowers and a few pods were observed. The methods for obtaining soil and plant tissue samples were identical during both harvests. Each rack holding a cone-tainer at the shade-house was transferred to a washing station outside of the CTPC garden house. Each cone-tainer was gently pressed to loosen the soil, and the contents were then emptied on a plastic tray. A total of three leaves were collected from each plant, and stored in coin envelopes for a nutrient 
analysis. Shoots were separated from roots by cutting them with a clipper, and then placed in a paper bag to be dried and weighed. Soil samples were collected in $5 \mathrm{~mL}$ soil collecting bags (Whirl-pak) for analysis of diversity of fungal spores (Scharnagl, 2013). All remaining soils were added to the CTPC compost pile to be re-used. Roots were carefully rinsed using a hose with low water pressure. The entire root system, including all nodules and root tips that detached form the rinsing process were stored in Ziploc plastic bags for further analysis. All bags used for this experiment were pre-labeled before each harvest with the assigned numbers created to identify each plant based on the plant species, soil type, pot size, salinity treatment, and replicate.

After each harvest, all root and soil samples were stored in a $4^{\circ} \mathrm{C}$ refrigerator in Dr. von Wettberg's laboratory, while leafs and shoots were stored at room temperature. Harvested roots were further rinsed in the lab, and all nodules were collected, counted, and stored in cluster tube boxes. Nodules were stored at $-20^{\circ} \mathrm{C}$ until they were retrieved for DNA isolation. Root tips were collected in order to identify mycorrhizal percent colonization, as part of an analysis conducted by former graduate student Klara Scharnagl (Scharnagl, 2013). All roots and shoots were then dried for three days using the oven at Dr. von Wettberg's laboratory, and the dry root and shoot weights were recorded.

\section{III-D. Plant fitness measures}

In order to investigate the relationship of rhizobial partners and legume performance while growing in different pine rockland soils, several measurements were used as proxies for plant fitness values. These included growth rate, shoot biomass, root biomass, total nitrogen content, and nodule number. 
The second harvest had to be performed before fruits started to set, as nodules senesce at flowering in legumes, and as a consequence, reproductive fitness could not be measured. Biomass and growth rates are commonly used proxies for plant fitness, as well as aboveground total nitrogen to determine the benefits provided by rhizobia. Nodule weight and number are indicators of how successful the symbiosis between the host and microbe is. A plant often nourishes a larger nodule, but the nature of sanctions in legumes is not fully understood, even in model legumes (Kiers et al., 2003; Friesen and Heath, 2013). Furthermore, how mixed microbial communities affect plant performance remains poorly understood (Kiers et al., 2013; Friesen and Heath, 2013).

Growth rate was measured as the average change in plant height in $\mathrm{cm} /$ week. For the first harvest, the growth rate covered an eight-week period, while harvest two covered a growth period of twelve weeks. Negative heights were observed occasionally, which was attributed to dieback, branching, and some sporadic changes in soil levels as a result of compaction or erosion. Even though changes in plant growth over time can be good indicators of plant fitness, these measurements by themselves are not ideal.

After all nodules and root tips were collected, roots were stored in labeled paper bags, and allowed to dry at room temperature for a period of 48 hours. These were then placed in a drying oven at $80^{\circ} \mathrm{C}$ for three days. Dry root weight was then recorded by weighing these on an electronic balance. Shoots, which were stored in paper bags at the lab, had remained at room temperature. They were placed in the drying oven at $80^{\circ} \mathrm{C}$ for two days, and dry shoot weight was recorded by weighing these on an electronic balance. 


\section{III-E. Nutrient analysis}

After completing all soils collection from the different pine rockland sites, samples were gathered from each soil type in $5 \mathrm{~mL}$ Whirl-pak soil collection bags, and send to A\&L Southern Agricultural Laboratories, LLC for a preliminary soil nutrient content analysis. The nutrients analyzed included potassium, magnesium, calcium, sodium and nitrate.

Dried shoots were grinded using a mortar and pestle, weighed, placed in small aluminum foil crucibles, and wrapped up to be tested for nitrogen content. This analysis was performed using a Carbon-Nitrogen Elemental Analyzer at the Soil-Plants Analytical Laboratory at Florida International University.

\section{III-F. Molecular analysis}

After nodules were collected from plant roots, only twelve from each plant (when available) or less were randomly selected and stored at $-80^{\circ} \mathrm{C}$ to be utilized for DNA isolation. When more than twelve nodules per plant were available, the remaining ones were stored in coin envelopes and also kept at $-80^{\circ} \mathrm{C}$ in case more nodule material was required. For each plant that nodulated, a minimum of $20 \mathrm{mg}$ of nodule tissue was required in order to obtain a good DNA yield. Each nodule was weigh (mg) using an analytical balance.

DNA was isolated using the QIAGEN DNeasy Plant Tissue (Mini Protocol). Manufacturer instructions were followed, with the exception of the homogenization step, in which the tissue was disrupted in the presence of a cell-lysing buffer (Buffer AP1), instead of using liquid nitrogen as suggested by the QIAGEN protocol. This adjustment resulted in better DNA yields. A total of $100 \mu \mathrm{L}$ of genomic DNA was obtained from 
each extracted nodule, and collected in $2 \mathrm{~mL}$ Eppendorf microcentrifuge tubes. All DNA samples were quantified using the Qubit Fluorometer, and concentrations were recorded in $\mathrm{ng} / \mu \mathrm{L}$. To verify the presence of genomic DNA, all samples were visualized through gel electrophoresis using a $1 \%$ agarose gel, and a 50-2,000 base pair molecular ladder. All DNA samples were stored at $-80^{\circ} \mathrm{C}$.

A total of 10 samples per species were selected for polymerase chain reaction (PCR) amplification and sequencing. The symbiosis related gene nifH was amplified using the primer pair 5'- GTCTCCTATGACGTGCTCGG-3' (nifH_F), and 5'GCTTCCATGGTGATCGGGGT-3' (nifH_R) as described by Rivas et al. (2002), under the following conditions: initial denaturation at $94{ }^{\circ} \mathrm{C}$ for 5 minutes, followed by 35 cycles of denaturation at $94^{\circ} \mathrm{C}$ for 30 seconds, annealing at $60^{\circ} \mathrm{C}$ for 30 seconds, and extension at $72^{\circ} \mathrm{C}$ for 30 seconds followed by a final extension at $72^{\circ} \mathrm{C}$ for 10 minutes. All PCR amplifications were verified through gel electrophoresis (1.4\% agarose), cleaned with ExoSAP-IT (Affymetrix, Santa Clara, CA, USA) and quantified using the Qubit Fluorometer (Life Technologies, Carlsbad, CA, USA).

Amplified products were directly sequenced with the Sanger-based method, which provides relatively long read lengths and low error rates (Blazej et al., 2006; Yao et al., 2006). Amplicons were sequenced using the BigDye Terminator cycle sequencing kit on a 3130XL ABI Genetic Analyzer (Applied Biosystems Inc., Foster City, CA, USA) at the FIU DNA Core Laboratory facility.

Sequences were edited using Sequencher 5.1 (sequence analysis software, Gene Codes Corporation, Ann Arbor, MI, USA), and Standard Nucleotide BLAST from NCBI (Altshul et al., 1990) was used to compare sequences against known sequences. Edited 
sequences were concatenated and aligned using MAFFT 7 (Katoh and Standley, 2013). Phylogenetic trees were constructed with MEGA 6 (Tamura et al., 2013) using maximum likelihood and UPGMA methods with the Kimura 2 parameter model + G (Gamma Distribution), and 1,000 and 10,000 bootstrap replications respectively. Sequences of Bradyrhizobium elkanii (GU433558), Bradyrhizobium japonicum (HM107280), Bradyrhizobium jicamae (HM047127), Bradyrhizobium sp. (DQ085617), and Sinorhizobium fredii (DQ485715) were included as outgroups in both trees.

Future amplifications and next generation sequencing will be done using primers I have designed based on rhizobia sequences available in GenBank. These primers were aligned using ClustalX 2.1 (Larkin et al., 2007), and tested for suitable amplification using Amplify 3.1 (Engels, 2005). The loci developed were for the housekeeping genes $16 \mathrm{~S}$ and 23S (16S_F_Rhiz 5'-CGGGGGAAAGATTTATCG-3'; 23S_R_Rhiz 5'CATTGCACTCGACGACC-3'), and the nitrogen fixating gene cluster nifK, nifH and nifD (nifH_F_Rhiz 5'-GCCGACTCCACCCGSCTSATCC-3'; nifK_R_Rhiz 5'TTGTTGCCGACGCAGAAGCC-3’).

\section{III-G. Statistical analysis}

The difference between the overall mean nodulation in harvests one, and harvest two was established by a Mann-Whitney test. Mean nodulation per species in harvest one and two per soil type, was compared using a Kruskal-Wallis test, and a Mann-Whitney test (post hoc) was used to determine the difference in mean nodulation between soil types by species. A similar test was done to determine the overall mean nodulation in both harvests in the presence or absence of a salinity treatment. Mean nodulation per species in harvest one and two per soil type under saline and non-saline conditions, were 
compared using a Kruskal-Wallis test, and a Mann-Whitney test (post hoc) was used to determine the difference in mean nodulation between soil types by species under saline and non-saline conditions. A Bonferroni correction was implemented to control Type I error for all pair wise comparisons. Statistical analyses were performed using SPSS 19 (SPSS Inc., 2009).

A correlation of traits was assessed separately for each species, salt treatment, and source soil combination in SAS 9.2 (SAS Institute, Cary, NC, USA) using PROC CORR. A correlation test was chosen to look at the relationship of factors because the patterns of causation are not clear. An analysis of variance (ANOVA) was implemented in SAS 9.2 (SAS Institute, Cary, NC, USA) with PROC GLM and Type III Sum of Squares to assess the relationship of nodulation parameters on plant total nitrogen, above and below ground biomass, and growth.

\section{RESULTS}

\section{IV-A. Soil nutrients}

Collected soils were analyzed for nutrient content, while plants were analyzed for growth rate, shoot dry biomass, root dry biomass, total nitrogen and nodulation. The

analysis was done per soil type, salinity treatment, and harvest. The effectiveness of nodulation was determined for each soil type during the two different harvest times, as well as in the presence of a saline or a non-saline treatment.

All sampled sites had very high levels of calcium (above $1400 \mathrm{ppm}$ ), which was expected given that pine rockland bedrock is comprised mainly of limestone (Figure 2). Soils from BPK and TREC had the highest calcium levels, while CTPC soils had the 
lowest. The highest sodium and magnesium levels were observed at BPK soils (722.3 ppm and 830.3 ppm respectively), which was anticipated since this pine rockland site is located on the coast of an island, being directly exposed to sea water intrusion and having experienced storm surge during 2005's hurricane Wilma (Saha et al., 2011). Overall, all four sites were found to have low nitrate and potassium levels, as a consequence of their karstic soil nature.

Dry shoot biomass and dry root biomass production differed significantly among the four pine rockland soils. Dry shoot weight (DSW) was significantly higher for all four host species in CTPC soils, followed by TREC soils (Figure 3 a, c, e, g). The lowest DSW was recorded in FIU soils (Figure 3 a, c, e, g), and no differences were found in the presence of the salinity treatment. Dry root weight (DRW) was significantly higher for all four host species in CTPC soils, followed by TREC soils (Figure $3 \mathrm{~b}, \mathrm{~d}, \mathrm{f}, \mathrm{h}$ ). The lowest DSW was recorded in BPK soils (Figure $3 \mathrm{~b}, \mathrm{~d}, \mathrm{f}, \mathrm{h}$ ).

\section{IV-B. Effects of soil type and salinity treatment in nodulation}

In order to determine the difference in the mean nodulation between the first and second harvest, an independent sample Mann-Whitney U Test was used. This test shows there is a significant difference between the two harvests $(z=-2.745, p<0.006$, Figure 4). In harvest two there were significantly more nodules than in harvest one (mean = 4.67, $\mathrm{SD}=5.38)$

In harvest one, for Cajanus cajan the total nodulation differed significantly among the different soil types $\left(\mathrm{X}_{3, \mathrm{n}=10}^{2}=9.00, \mathrm{p}=0.029\right.$, Table 1a). Soils from BPK, FIU, and Control did not significantly differ from each other, while soils from CTPT had the highest number of nodulation (Table 1a). For Chamaecrista fasciculata, the total 
nodulation differed significantly among soil types $\left(\mathrm{X}_{3, \mathrm{n}=11}^{2}=7.855, \mathrm{p}=0.049\right.$, Table $1 b$ ), and Control soils were found to have the least number of nodules (mean $=0.00, \mathrm{n}=$ 4, $\mathrm{SD}=0.000$ ). Soils from BPK, TREC, and CTPC did not significantly differed from each other. In Tephrosia angustissima, the total nodulation differed significantly among soil types $\left(\mathrm{X}_{4, \mathrm{n}=20}^{2}=15.096, \mathrm{p}=0.005\right.$, Table 1c). I found that BPK, CTPC, FIU and Control soils did not differed significantly form each other, while TREC had the highest mean nodulation $($ mean $=6.60, \mathrm{n}=5, \mathrm{SD}=5.079)$, and did not differ significantly from FIU and CTPC. For Abrus precatorious, the total nodulation differed significantly among soil types $\left(\mathrm{X}_{4, \mathrm{n}=27}^{2}=24.210, \mathrm{p}<0.001\right.$, Table 1d). Soils from BPK, FIU, and Control, did not exhibit any nodule formation, and did not significantly differ from each other. CTPC and TREC soils did not significantly differ from each other, but did exhibit nodulation.

In harvest two, for Cajanus cajan the total nodulation differed significantly among soil types $\left(X_{4, n=23}^{2}=18.471, p=0.001\right.$, Table 2a $)$. There was no significant difference between BPK, FIU, and Control, while CTPC and TREC had the highest nodulation $($ mean $=12.0$ and mean $=11.25$ respectively $)$ and did not differ significantly from each other. In Chamaecrista fasciculata, the total nodulation did not differ significantly among soil types $\left(\mathrm{X}_{4, \mathrm{n}=16}=6.518, \mathrm{p}=0.164\right.$, Table $\left.2 \mathrm{~b}\right)$. Soils from CTPC and TREC had the highest mean nodulation (mean $=9.4$ and mean $=10.33$ respectively). In Tephrosia angustissima, the total nodulation differed significantly among soil types $\left(\mathrm{X}_{4, \mathrm{n}}^{2}=25=15.830, \mathrm{p}=0.003\right.$, Table 2c $)$. Soils from BPK and FIU did not differ significantly and did not produce any nodules. Control soils exhibited an intermediate value, and did significantly differ from the other soil types. Soils from CTPC and TREC 
had the highest values $($ mean $=10.0$ and mean $=9.50$ respectively). For Abrus precatorious, the total nodulation differed significantly among soil types $\left(\mathrm{X}_{4, n}^{2}=36=\right.$ 28.98, $\mathrm{p}<0.001)$ Table 2d). Soils from BPK, FIU, and Control did not produce any nodules, while CTPC and TREC did exhibit nodulation $($ mean $=6.25$ and mean $=7.88$ respectively).

The obtained results for the salinity treatments indicate that there is no significant difference between overall nodulation in the presence of a saline or non-saline treatment (Mann-Whitney U Test, $\mathrm{z}=-0.73, \mathrm{p}<0.47, \mathrm{n}=168$, Figure 5). After comparing the different soil types per species in the presence or absence of a salinity treatment, there were no significant differences observed between the two (Table 3).

\section{IV-C. Effects of salinity treatment, soil source, and their interaction}

An analysis of variance (ANOVA) was used to determine the significance of salinity treatment, source soil, and their interaction on plant and rhizobial traits (Table 4), The ANOVA analyses for both harvests indicate that soil had a stronger effect on plant growth and nodulation than the salinity treatment. The salinity treatment did not significantly affect any plant performance variable. This is likely attributed to the sublethal nature of the salinity treatment, and the large differences among the soils.

\section{IV-D. Relationship between plant performance and nodulation}

In harvest one for Cajanus cajan in the absence of salt, dry shoot weight (DSW) and growth were positively correlated $(r=0.99, p<0.0001)$, as well as dry root weight (DRW) and growth $(\mathrm{r}=0.99, \mathrm{p}<0.0001)$ but other plant growth parameters were not. There was a weak correlation between DSW and DRW $(r=0.98, \mathrm{p}=0.0781)$. Nodule number was not correlated with any other parameter, and plant fitness traits were not 
correlated with nodule traits (Table 5a). In the presence of a salinity treatment, correlations between DSW and nodule number $(r=0.73, p=0.062)$, nodule number and growth $(r=0.73, p=0.0604)$ were marginally significant, while growth and total $\mathrm{N}(\mathrm{r}=$ $0.43, \mathrm{p}=0.06)$ were weakly correlated (Table $5 \mathrm{~b}$ ). Other plant growth and nodulation parameters were not significantly correlated.

For Chamaecrista fasciculata in the absence of salt, there was a marginal correlation between DRW and nodule number $(\mathrm{r}=0.91, \mathrm{p}=0.0702)$, and DSW and DRW $(r=0.93, p=0.0694)$. Other plant growth or nodulation parameters were not significantly correlated, and no plant growth or nodulation measures were associated with $\mathrm{N}$ levels (Table 5c). In the presence of a salinity treatment, there was a positive correlation between DSW and DRW $(r=0.84, \mathrm{p}=0.0311)$, DSW and growth $(\mathrm{r}=0.80, \mathrm{p}$ $<0.0001)$, and DRW and growth $(\mathrm{r}=0.98, \mathrm{p}<0.0001)$. Nodule number was significantly correlated with total $\mathrm{N}(\mathrm{r}=1, \mathrm{p}<0.0001)$, but there was no significant correlation with any other parameter, and plant fitness traits were not correlated with nodule traits (Table $5 d)$.

For Tephrosia angustissima in the absence of salt, there was a significant correlation between DSW and DRW $(r=0.93, p=0.0028)$, DSW and nodule number $(r=$ $0.99, \mathrm{p}<0.0001)$, DRW and total $\mathrm{N}(\mathrm{R}=0.68, \mathrm{p}=0.005)$, as well as for DRW and nodule number $(r=0.90, p=0.005)$. There was no significant correlation between growth and other plant fitness traits or nodulation (Table 5e). In the presence of a salinity treatment, there were no correlations found, since the sample size was too low to estimate these values (Table 5f). 
For Abrus precatorious in the absence of salt, DSW was significantly correlated with total $\mathrm{N}$ and nodule number $(\mathrm{r}=0.50, \mathrm{p}=0.0245 ; \mathrm{r}=0.57, \mathrm{p}=0.0031)$, as well as DRW and nodule number $(\mathrm{r}=0.50, \mathrm{p}<0.0001)$. However, neither growth nor total nitrogen were correlated with either biomass measurements or each other (Table $5 \mathrm{~g}$ ). In the presence of salt, DSW was significantly correlated with nodule number $(\mathrm{r}=0.69, \mathrm{p}=$ 0.0127), but there was no significant correlation between growth and other plant fitness traits or nodulation (Table $5 \mathrm{~h}$ ).

In harvest two for Cajanus cajan in the absence of salt, there was a significant correlation between DSW and DRW $(r=0.77, p=0.0453)$, DSW and growth $(r=0.61, p$ $=0.0453)$, and DRW and nodule number $(\mathrm{r}=0.87, \mathrm{p}=0.0005)$. The correlation between DSW and total $\mathrm{N}$ was weak, but trended towards positive correlation $(\mathrm{r}=0.49, \mathrm{p}=$ 0.0108). There was a negative correlation between DRW and total $\mathrm{N}(\mathrm{r}=-0.90, \mathrm{p}=$ 0.0005 ), and there were no significant correlations between total $\mathrm{N}$ and any other plant fitness traits or nodulation (Table 6a). In the presence of salt, there was a significant correlation between DSW and DSW $(r=0.97, \mathrm{p}=0.00186)$, DSW and nodule number $(\mathrm{r}$ $=0.73, \mathrm{p}=0.0494)$, DRW and nodule number $(\mathrm{r}=0.73, \mathrm{p}=0.0373)$, and DSW and growth $(\mathrm{r}=0.66, \mathrm{p}=0.0186)$. However, no plant growth or nodulation measures were associated with $\mathrm{N}$ levels (Table 6b).

For Chamaecrista fasciculata in the absence of salt, there was a significant correlation between DSW and DRW $(r=0.97, p=0.0012)$, DSW and growth $(r=0.80, p$ $<0.0001)$, DSW and nodule number $(\mathrm{r}=0.64, \mathrm{p}=0.0029)$, DRW and growth $(\mathrm{r}=0.67, \mathrm{p}$ $<0.0001)$, and DRW and nodule number $(\mathrm{r}=0.63, \mathrm{p}=0.0024)$. There was a weak correlation between growth and nodule number $(\mathrm{r}=0.68, \mathrm{p}=0.0719)$, and no plant 
growth or nodulation measures were associated with $\mathrm{N}$ levels (Table $6 \mathrm{c}$ ). In the presence of salt, patterns were similar. There was a significant correlation between DSW and DRW $(r=0.89, p=0.0005)$, DSW and growth $(r=0.64, p<0.0001)$, DRW and growth $(\mathrm{r}=0.62, \mathrm{p}<0.0001)$. Nodule number was significantly correlated with DSW, DRW, and growth $(\mathrm{r}=0.76, \mathrm{p}=0.0047 ; \mathrm{r}=0.63, \mathrm{p}<0.0001 ; \mathrm{r}=0.84, \mathrm{p}=0.0286)$. No plant growth or nodulation measures were associated with $\mathrm{N}$ levels (Table $6 \mathrm{~d}$ ).

For Tephrosia angustissima in the absence of salt, there was a negative correlation between DSW and growth $(\mathrm{r}=-0.99, \mathrm{p}<0.0001)$, and there were no positively correlated components estimated given the low sample size (Table 6e). Similar results were obtained in the presence of salinity were no correlations could be estimated (Table 6f).

For Abrus precatorious in the absence of salt, there was a significant correlation between DSW and DRW $(r=0.96, p<0.0001)$, as well as for growth and total N $(r=1, p$ $=0.0359)$. Nodule number was also significantly correlated with SDW, RDW, and growth $(\mathrm{r}=0.90, \mathrm{p}=0.0023 ; \mathrm{r}=0,89, \mathrm{p}=0.0101 ; \mathrm{r}=0.51, \mathrm{p}=0.0052)$. However, there was a negative correlation between shoot and root biomass and total $\mathrm{N}(\mathrm{r}=-1, \mathrm{p}<$ $0.0001 ; \mathrm{r}=-1, \mathrm{p}<0.0001)($ Table $6 \mathrm{~g})$. In the presence of salt there was a significant correlation between shoot and root biomass $(\mathrm{r}=0.93, \mathrm{p}=0.0014)$, shoot and root biomass with growth $(\mathrm{r}=0.68, \mathrm{p}<0.0001 ; \mathrm{r}=0.67, \mathrm{p}<0.0001)$, shoot and root biomass with nodule number $(\mathrm{r}=0.74, \mathrm{p}<0.0001 ; \mathrm{r}=0.66, \mathrm{p}<0.0001)$, and nodule number with growth $(\mathrm{r}=0.64, \mathrm{p}=0.0033)$. No plant growth or nodulation measures were associated with $\mathrm{N}$ levels (Table 6h). 


\section{IV-E. Phylogenetic analyses}

I sequenced 431 base pairs of the symbiosis related gene nifH. Among the 40 isolates I found four variable sites. Results obtained from a BLAST analysis determined that there was no clear division of rhizobial strains among the four host species, since all sequences belong to the genus Bradyrhizobium spp. Maximum likelihood and UPGMA analyses of the nifH DNA sequences yielded highly similar tree topologies and indicated that the sequences fall into roughly four clades.

According to the maximum likelihood single gene phylogenetic tree (Figure 6), group A has sequences most similar to Bradyrhizobium sp. with a supporting bootstrap value of 79; group B has sequences similar to Bradyrhizobium jicamae with a supporting bootstrap value of 70; group C was not found to be similar to any of the Bradyrhizobium linages used as outgroups; and group D has sequences similar to Bradyrhizobium elkanii with a supporting bootstrap value of 52. Bradyrhizobium japonicum and Sinorhizobium fredii were clustered as outgroups. There was no rhizobial community shift between salinity treatment and soil type (Figure 7).

Topologies of the single gene UPGMA phylogenetic tree were similarly distributed (Figure 8). Group A has sequences most similar to Bradyrhizobium sp. with a supporting bootstrap value of 87; group B has sequences similar to Bradyrhizobium jicamae with a supporting bootstrap value of 75; group $\mathrm{C}$ was not found to be similar to any of the Bradyrhizobium linages used as outgroups; and group D has sequences similar to Bradyrhizobium japonicum and Bradyrhizobium elkanii with supporting bootstrap values of 68 and 59 respectively. Sinorhizobium fredii was chosen as an outgroup to root 
the tree. Furthermore, there was no clear shift in rhizobial strains between the salinity treatments and soil type (Figure 9).

\section{DISCUSSION}

This experiment demonstrates the effects of rhizobia on their legume plant host in pine rockland soils under normal and saline conditions. There was a significant difference in the growth performance and nodulation of the legume host species across the four different pine rockland soils, but no significant effect was observed when exposed to a salinity treatment. This is in part because it was a light salt treatment, and in part that most of the data was obtained from relatively early in the lifespan before the salt level had a chance to build up.

Towards the beginning of the experiment plant growth was observed to be slow, followed by much faster growth in later weeks. This could be attributed to developmental patterns of each species, as well as the heavy rains experienced during the beginning of planting, followed by sunny days and sporadic rains, possibly altering plant growth patterns. Also, this initial water saturation may have affected seedling germination and growth, and could have also impacted the initial legume-rhizobium symbiotic association by creating an adaptation challenge to the prevalent rhizobia populations, and their ability to infect their plant hosts.

For all four legume species, nodulation was highest in CTPC and TREC soils, which were the most undisturbed pine rockland sampled sites. There was no significant difference in nodulation when these soils were exposed to salinity. For all legumes hosts, the lowest nodulation was observed in FIU and BPK soils, which were the two most 
disturbed sampled pine rockland sites. Mean nodulation was significantly higher in harvest 2 than it was in harvest 1 . Plants in harvest 2 were considerably more robust and closer to flowering which could have lead to better developed nodules.

Soil differences were substantial. Fertility of the BPK soils was particularly low in part to the already high salinity found on these soils. This site was severely impacted by storm surge from hurricane Wilma and a subsequent drought in 2005 . Those events have led to a dieback of many of the pines that dominate pine rocklands on Big Pine Key (Saha et al., 2011). In areas with die back, as well as in neighboring tropical hammock forests, the plant communities are transitioning towards buttonwood, mangroves, and other salt tolerant communities (Hughes personal communication). For glycophytic species to remain in these increasingly saline communities, like most of the 75 legume species known to occur in the Florida Keys (Gann et al., 2014), some salt tolerance is necessary. In legumes, the ability to retain their symbiosis with rhizobia in increasingly saline soils is important for their persistence in the face of sea level rise, shrinking fresh water lenses, and storm surge from hurricanes. However, my results show no difference in rhizobial associates between BPK and the three mainland pine rockland soils, which suggests that if legumes from the Keys were to be moved to high grounds on the Florida mainland or elsewhere to protect them from habitat loss and other low lying areas (Maschinski et al., 2011), such translocations will move legumes to soils where suitable rhizobia are already likely to be present. This finding is also useful for potential restoration plantings.

In harvest one, the root system of several pants was not well developed and therefore the smaller plants were found to have lesser nodules. Since no nodules were 
observed, former student Klara Scharnagl used these smaller roots for mycorrhizal percent colonization. It is not surprising to have fewer nodules on smaller plants. However, one would expect seedlings to require some nodules to provide nitrogen for further growth. It is worth future investigation to determine if there are differences between early and later growth in the rhizobial partners selected by these legumes.

In harvest two, the plants growing bigger and healthier were observed in CTPC soils, followed by TREC soils, which were the least disturbed pine rockland locations, while the smallest plant growth was observed in FIU soils and BPK soils. Some nodulation was observed in Control soils on both harvests, which were initially autoclaved to remove existing microorganisms. This unexpected outcome could be a result of an unsuccessful autoclaving process, and cross contamination by the herbivores present in the shade house. Furthermore, it is possible that some rhizobia are distributed by rain or by splashing.

All four legume hosts behaved similarly in terms of selecting a symbiotic partner. It was expected that the crop and invasive species would be least reliant on symbiotic partners since both species have a recent evolutionary history of occurring in novel soils where their symbiotic partners may be absent. Cajanus cajan is a crop known for its ability to associate with a variety of mycorrhizal fungi, but its symbiotic rhizobia are less well characterized. However, in this experiment it appears to make a symbiotic relationship with the same rhizobia used by the native legumes Tephrosia angustissima and Chamaecrista fasciculata. In a similar way, the invasive legume Abrus precatorious also formed symbiosis with the same rhizobia as the native species. Since mutualism can 
limit range of expansion, utilizing native rhizobia could be essential for an exotic legume to establish if it is distributed to a new range without its native rhizobia (Parker, 2001).

Symbiotic Bradyrhizobium strains have been isolated from nodules of highly divergent legume tribes, including herbaceous and woody legume species from tropical and temperate regions (Sprent, 2001; Menna et al., 2006). Studies in eastern North America have demonstrated how Chamaecrista and Tephrosia are known to form a symbiotic relationship with the genus Bradyrhizobium, more specifically with Bradyrhizobium elkanii (Parker and Kennedy, 2006; Stanton-Geddes and Anderson, 2011). In this experiment, maximum likelihood and UPGMA phylogenetic trees of the symbiosis related gene nifH show four variable sites among the 40 isolates, from which it was inferred that Bradyrhizobium spp. was present in all nodules/soils forming symbiosis with all four host legumes. According to both phylogenetic trees, there was no pattern on Bradyrhizobium symbiotic association based on host legume species. The maximum likelihood analyses show that Group A has sequences most similar to Bradyrhizobium sp.; group B has sequences similar to Bradyrhizobium jicamae; group C was not found to be similar to any of the Bradyrhizobium linages used as outgroups; group D has sequences similar to Bradyrhizobium elkanii, and there was no rhizobial community shift between salinity treatment and soil type. Phylogenetic UPGMA analyses show that group A has sequences most similar to Bradyrhizobium sp.; group B has sequences similar to Bradyrhizobium jicamae; group C was not found to be similar to any of the Bradyrhizobium linages used as outgroups; group D has sequences similar to Bradyrhizobium japonicum and Bradyrhizobium elkanii. Furthermore, there was no clear shift in rhizobial strains between the salinity treatments and soil type. By selecting two 
different harvest times, it could be possible to determine if microbial communities on the hosts shift over the hosts' lifetime. However, no rhizobial shift was observed based on the phylogenetic analyses of the nifH gene.

Even though there were three replicates made for each cross of soil/plant/conetainer size/salinity, as a consequence of heavy rains, a number of seeds did not germinate, and several plants died while the experiment was taking place. These unexpected factors reduced the number of replicates, which in some cases represented an inconvenient to perform a thorough statistical analysis. If this experiment was to be replicated, it is recommended to do it under more controlled conditions, preferably under a greenhouse setting, and avoid initiating planting during the Florida summer.

By conducting research integrating systematics, population genetics, and functional approaches to understanding legume-symbiont biodiversity in a threatened community, we could uncover the aspects of biodiversity necessary to better understand microbial diversity in soils and the applied information necessary to make more informed conservation decisions, like inoculating restoration plantings with suitable microbial partners like rhizobia and mycorrhizae. Symbiotic associations can improve a plants ability to uptake nutrients, since mutualists can alter plant functional traits, and therefore mediate ecological, evolutionary and ecosystem processes (Friesen et al., 2011). Therefore, the characterization of symbiotic microbial diversity, the degree in which they improve environmental quality, their preferred host species and plant community structure, are critical to better understand the role of these symbionts as agents of productivity in natural populations, thus providing tools to develop improved management, conservation and restoration practices. 


\section{FUTURE DIRECTIONS}

Following the amplification of the $16 \mathrm{~S}, 23 \mathrm{~S}$ and the nifHDK cluster, next generation sequencing will be carried out using Illumina and Ion Torrent platforms, which allow to generate a large number of sequenced data across several loci, by providing thousands of operational taxonomic units (OTU) (Bybee et al., 2011). For sequencing analysis and alignment, I will use several online programs and tools like TCoffee, ClustalW2, and Oligo Calc that will allow me to assess the differences among host plant species, soil, and salinity treatment. In addition, I will use the sequenced data for population genetic analyses. I will circumscribe OTU's based on $97 \%$ and $99 \%$ sequence similarity. I will then calculate levels of divergence and gene flow among different factors for each OTU using population genetic software such as GenAlEx and STRUCTURE. I will calculate migration rates with the program MIGRATE, and I will look for population bottlenecks with Approximate Bayesian Computation, implemented in DIYABC.

By amplifying the housekeeping genes (16S and 23S) and nitrogen fixation related genes (nifH, nifD, and nifK), I expect to further characterize which rhizobial symbionts are present on each studied pine rockland area. Also, I expect to find rhizobial variation between the four different pine rockland soils, as well as variation between the species that form symbiosis with each of the four host plant. As a result of the complex interactions that take place between host root, rhizobia, and the environment for the formation of nodules, I expect to find different rhizobia forming symbiosis with the different legumes. Moreover, I expect differences in both the nodulation process as well as in the rhizobial diversity between saline and non-saline conditions. The lowest 
diversity is expected in the Florida Keys soils because the landmass area is the smallest in this location. Furthermore, I expect the smallest differences between saline and nonsaline treatments in Big Pine Key samples, because these soils are the most saline given the shallow freshwater lens in the Keys and the recent history of storm surge from Hurricane Wilma in 2005 (Saha et al., 2011). I expect to find differences in rhizobial communities based on their host plant, with crops and exotics utilizing a greater range of rhizobial strains, as well as an increase in the variation of rhizobia within each remaining forested area. 


\section{LIST OF REFERENCES}

Allen, O.N., and Allen, E.K. (1981). The Leguminosae: A Source Book of Characteristics, Uses and Nodulation. University of Wisconsin Press, Madison \& Macmillan Publishers, London.

Alexander, T.R. (1967). A Tropical Hammock in the Miami (Florida) Limestone: A Twenty-Five Year Study. Ecology 48:863-867.

Alonso, J., Heinen, J.T. (2011). Miami Dade County's Environmentally Endangered Lands Program: Local Efforts for a Global Cause. Natural Areas Journal 31(2): 183-189.

Altshul, S.F., Gish, W., Myers, E.W., and Lipman, D.J. (1990). Basic Local Alignment Search Tool. J. Mol. Biol. 215: 403-410.

Ambasta S.P. (2004). The Useful Plants of India 4th ed. New Delhi: National Institute of Science Communication pp. 94-5.

Audet, P., and Charest, C. (2010). Identification of Constraining Experimental Design Factors in Mycorrhizal Pot-Growth Studies. Journal of Botany 2010:1-6.

Blazej, R.G., Kumaresan, P., and Methies, R.A. (2006). Microfabricated bioprocessor for integrated nanoliter-scale Sanger DNA sequencing. Proc. Natl. Acad. Sci USA 103:7240-7245.

Bonfante, P., and Genre, A. (2010). Mechanisms Underlying Beneficial Plant-Fungus Interactions in Mycorrhizal Symbiosis. Nature Communications DOI:10.1038/ncomms1046.

Bybee, S.M., Bracken-Grissom, H., Haynes, B.D., Hermansen, R.A., Byers, R.L., Clement, M.J., Udall, J.A., Wilcox, E.R., Crandall, K.A. (2011) Targeted amplicon sequencing (TAS): A scalable next-gen approach to multi-locus, multitaxa phylogenetics. Genome Biology and Evolution doi:10.1093/gbe/evr106.

Cereal Knowledge Bank (2009). The importance of Legumes in Cereal Cropping Systems. http://www.knowledgebank.irri.org/ckb/agronomy-maize/theimportance-of-legumes-in-cereal-cropping-systems.html.

Dade County Park and Recreation Department (1993). Charles Deering Estate Management Plan. Dade County Park and Recreation Department; Miami, Florida. 
Department of Environmental Resources Management (DERM) Dade County (1993). Endangered Pine Rockland Plant Species Recovery Project: Draft Annual Report. Submitted to the U.S. Fish and Wildlife Service. Cooperative agreement \# 14-160004-91-951.

Department of Environmental Resources Management (DERM) Dade County (1994). Management Plan for the Richmond Pine Rocklands. Report Prepared for the U.S. Fish and Wildlife Service Under Grant \#14-16-0004-92-987.

Doyle, J.J., Luckow, M.A. (2003). The Rest of the Iceberg. Legume Diversity and Evolution in a Phylogenetic Context. Plant Physiology 131, pp. 900-910.

Engels, B. (2005) Amplify 3.1 wrengels@facstaff.wisc.edu

Firth, P., Thitipoca, H., Suthipradit, S., Wetselaar, R., Beech, D.F. (1973). Nitrogen Balance Studies in the Central Plain of Thailand. Soil Biology Biochemistry 5: 41-46.

Friesen, M.L., and Heath, K.D. (2013). One Hundred Years of Solitude: Integrating Single-Strain Inoculants with Community Perspectives in the Legume-Rhizobium Symbiosis. New Phytologist 189:7-9.

Friesen, M.L., Porter, S.S., Stark, S.C., von Wettberg, E.J., Sachs, J.L. and MartinezRomero, E. (2011). Microbial Mediated Plant Functional Traits. Annual Review of Ecology, Evolution and Systematics 42:23-46.

Gann, G.D., Bradley, K.A., and Woodmansee, S.W. (2014). The Floristic Inventory of South Florida Database Online. The Institute for Regional Conservation. Delray Beach, Florida USA.

Gepts, P. (2004). Crop Domestication as a Long-Term Selection Experiment. Plant Breeding Reviews, volume 24, Part 2.

Gilpin, M. E., Soulé, M. E. (1986). Minimum Viable Populations: Processes of Species Extinction. In Conservation Biology: The Science of Scarcity and Diversity, ed. M. E. Soulé (Sunderland: Sinauer \& Associates, 1986): 19-34.

González-Rodriguez, A., Benrey, B., Castañeda, A., Oyeda, K. (2000). Population Genetic Structure of Acanthoscelides obtectus and A. obvelatus (Coleoptera: Bruchidae) from Wild and Cultivated Phaseolus spp. (Leguminosae). Ann. Entom. Soc. Am. 93: 1100-1107.

Hirsch, A.M, Lum, M.R., Downie, A. (2001). What makes the rhizobia-legume symbiosis so special? Plant Physiology 127, pp. 1484-1492.

IUCN Red List (2012) http://www.iucnredlist.org/details/19892512/0 
Katoh, K., Standley, D.M. (2013). MAFFT Multiple Sequence Alignment Software Version 7: Improvements in Performance and Usability, molecular Biology and Evolution: 30 772-780.

Kiers, T.E, Rousseau, R.A., West, S.A., Denison, R.F. (2003). Host Sanctions and the Legume-Rhizobium Mutualism. Nature 425, 78-81.

Kiers, T.E., Ratcliff, W.C., Denison, R.F. (2013). Single-Strain Inoculation May Create Spurious Correlations Between Legume Fitness and Rhizobial Fitness. New Phytologist 198: 4-6.

Koptur, S. (2006). The Conservation of Specialized and Generalized Pollination Systems in Subtropical Ecosystems: A Case Study. 341-61 in N Waser, J Ollerton, eds. Plant-Pollinator: From specialization to generalization. University of Chicago Press, Chicago.

Larkin, M.A., Blackshields, G., Brown, N.P., Chenna, R., McGettigan, P.A., McWilliam, H., Valentin, F., Wallace, I.M., Wilm, A., Lopez, R., Thompson, J.D., Gibson, T.J., Higgins, D.G. (2007). Clustal W and Clustal X version 2.0. Bioinformatics, 23:2947-2948.

Loope, L.L. and Dunevitz, V.L. (1981). Impact of Fire Exclusion and Invasion of Schinus terebinthifolius on Limestone Rockland Pine Forests of Southeastern Florida. South Florida Research Center report T-645.

Maschinski, J., Ross, M.S., Liu, H., O’Brien, J., von Wettberg, E.J. and Haskins, K.E. (2011). Sinking Ships: Conservation Options for Endemic Taxa Threatened by Sea Level Rise. Climate Change 107:147-167.

Menna, P., Hungria, M., Barcellos, F. G., Bangel, E. V., Hess, P. N. and MartinezRomero, E. (2006). Molecular phylogeny based on the 16S rRNA gene of elite rhizobial strains used in Brazilian commercial inoculants. Syst Appl Microbiol 29, 315-332.

Miami-Dade County Code (2005). Chapter 24-50.5(1)(c). (Loose-leaf supplement \#44), Creation of the Environmentally Endangered Lands Acquisition Trust Fund, p.3436 (Ord. No. 04-214, 1, 5, 12- 2-04).

Noss, R. F. and Peters, R. L. (1995). Endangered Ecosystems. A Status Report on America's Vanishing Habitat and Wildlife. Defenders of Wildlife, Washington, DC.

O'Brien, J.J. (1998). The Distribution and Habitat Preference of Rare Galactia Species (Fabacea) and Chamaesyce deltoidea Subspecies (Euphorbiaceae) Native to Southern Florida Pine Rockland. Natural Areas Journal 18:208-222. 
Parker, M.A. (2001) Mutualism as a constrain on invasion success for legume and rhizobia. Divers Dist 7:125-136.

Parker, M.A., Kennedy, D.A. (2006). Diversity and relationships of Bradyrhizobia from legumes native to eastern North America. Canadian Journal of Microbiology 52:1148-1157.

Peoples, M. B., Herridge, D. F., Ladha J. K. (1995). Biological Nitrogen Fixation: An Efficient Source of Nitrogen for Sustainable Agricultural Production. Plant Soil 174:3-28.

Peoples, M.B., Herridge, D.F., Ladha, J. K. (2005). Biological Nitrogen Fixation: An Efficient Source of Nitrogen for Sustainable Agricultural Production. Plant Soil 174:3-28.

Perret, X., Staehelin, C., Broughton, W.J. (2000). Molecular Basis of Symbiotic Promiscuity. Microbiol. Mol. Biol. Rev. 64, 180-201.

Postgate, J. R. (1982). The Fundamentals of Nitrogen Fixation. Cambridge University Press, Cambridge, United Kingdom.

Requena, N., Perez-Solis, E., Azcón-Aguilar, C., Jeffries, P., Bareal, J.M. (2001). Management of Indigenous Plant-Microbe Symbiosis Aids Restoration of Desertified Ecosystems. Applied and Environmental Microbiology 67 (2): 495498.

Rivas, R., Velázquez, E., Willems, A., Vizcaíno, N., Subba-Rao, N.S., Mateos, P.F., Gillis, M., Dazzo, F.B., Martínes-Molina, E. (2002). A new species of Devosia that forms a unique nitrogen-fixing root symbiosis with the aquatic legume Neptunia natans (L.f.) Druce. Applied and Environmental Microbiology. 68, 5217-5222.

Ross, M.S., O'Brien, J.J., Sternberg, L.S.L. (1994). Sea-Level Rise and the Reduction in Pine Forests in the Florida Keys. Ecological Applications 4 (1), 1994, pp. 144156.

Saha, S., Bradley, K., Ross, S., Hughes, P., Wilmers, T., Riuz, P.L., Bergh, C. (2011). Hurricane effects on subtropical pine rocklands of the Florida Keys. Climatic Change DOI 10.1007/s10584-011-0081-1.

Saha, A., Saha, S., Sadle, J., Jiang, J., Ross, M.S., Price, R., Sternberg, L. and Wendelberg, K. (2011). Sea Level Rise and South Florida Coastal Forests. Climatic Change 107 (1): 81-108. 
Salter, P.J., and Drew, D.H. (1965). Root growth as a factor in the response of Pisum sativum L. to irrigation. Nature 206, 1063-1064.

SAS Institute Inc. V9.2 (2011) Cary, NC, USA.

Scharnagl, K. (2013). The Effects of Arbuscular Mycorrhizal Fungi on Four Legume Hosts in South Florida Pine Rockland Soils. (Unpublished Master's Thesis). Florida International University, Miami, FL.

Singer, S.R., Maki, S.L., Farmer, A.D., Ilut, D., May, G.D., Cannon, S.B., Doyle, J.J. (2009). Venturing Beyond Beans and Peas: What Can We Learn From Chamaecrista? Plant Physiolohy 151, 1041-1047.

Snyder, J.R., Herndon, A., Robertson, W.B. (1990). South Florida rockland. Pages 230277 In R. L. Myers and J. J. Ewel, eds. Ecosystems of Florida. University of Central Florida Press; Orlando, Florida.

Snyder, J.R., Ross, M.S., Koptur, S., Sah J.P. (2005). Developing Ecological Criteria for Prescribed Fire in South Florida Pine Rockland Ecosystems USGS Open File Report OF 2006-1062.

SPSS Inc. (2009). SPSS 19 for Windows. Chicago, IL SPSS Inc.

Sprent, J.I. (1999). Nitrogen fixation and growth of non-crop legume species in diverse environments. Perspectives in Plan Ecology, Evolution and Systematics 2, 149162.

Sprent, J.I. (2001). Nodulation in Legumes. Kew, UK: Royal Botanic Gardens.

Sprent, J.I. (2007). Evolving Ideas of Legume Evolution and Diversity: A Taxonomic Perspective on the Occurrence of Nodulation. New Phytologist 174: 11-25.

Sprent, J.I. (2009). Legume Nodulation; A Global Perspective. Wiley-Blackwell, United Kingdom, pp.79.

Sprent, J.I., and Sprent P. (1990). Nitrogen Fixing Organisms. Pure and Applied Aspects. Chapman \& Hall, London, United Kingdom.

Sprent, J.I., Sutherland J., de Farias, S.M. (1987). Some Aspects of the Biology of Nitrogen-Fixing Organisms. Philosophical Transactions of the Royal Society of London, B 317: 111-119.

Stanton-Geddes, J., Anderson, C.G. (2011). Does facultative mutualism limit species range expansion? Oecologia 167:149-155. 
Subba-Rao N. S. (1980). Crop responses to microbial inoculation. In Recent advances in nitrogen fixation. Ed Subba Rao N. S. (Edward Arnold, London, United

Kingdom), pp 406-420.

Sullivan, P. (2003). Overview of Cover Crops and Green Manures. Fundamentals of Sustainable Agriculture. Fayetteville, AR: ATTRA - National Sustainable Agriculture Information Service.

Tamura, K., Stecher, G., Peterson, D., Filipski, A., and Kumar, S. (2013). MEGA6: Molecular Evolutionary Genetics Analysis version 6.0. Molecular Biology and Evolution: 30 2725-2729.

Tan, Z.Y., Wang, E.T., Peng, G.X., Zhu, M.E., Martinez-Romero, E., Chen, W.X. (1999). Characterization of Bacteria Isolated from Wild Legumes in the NorthWestern Regions of China. Int. J. Syst. Bacteriology 49, 1457-1469.

Thrall, P.H., Laine, A.L., Broabhurst, L.M., Bagnall, D.J., Brockwell, J., Cannon, S.B., Doyle, J.J. (2011). Symbiotic Effectiveness of Rhizobial Mutualists Varies in Interactions with Native Australian Legume Genera. PLos ONE 6(8): e23545. Doi:10.1371/journal.pone.0023545.

Unkovich, M., Herridge, D., Peoples M., Cadisch, G., Boddey B., Giller, K., Alves, B., Chalk, P. (2008). Measuring Plant-Associated Nitrogen Fixation in Agricultural Systems. Australian Centre for International Agricultural Research (ACIAR). www.aciar.gov.au.

U.S. Fish and Wildlife Service. (1999). Multi-Species Recovery Plan for South Florida. Pine Rocklands. www.fws.gov/southeast/vbpdfs/commun/pr.pdf.

Varshney, R.K., Chen, W., Li, Y., Bharti, A.K., Saxena, R.K., Schlueter, J.A., Donoghue, M.T.A., Azam, S., Fan, G., Whaley, A.M., Farmer, A.D., Sheridan, J., Iwata, A., Tuteja, R., Penmetsa, R.V., Wu, W., Updadhyaya, H.D., Yang, S.P., Shah, T., Saxena, K.B., Michel, T., McCombie, W.R., Yang, B., Zhang, G., Yang, H., Wang, J., Spillane, C., Cook, D.R., May, G., Xu, X., and Jackson, S.A. (2012). Draft genome sequence of pigeonpea (Cajanus cajan), an orphan legume crop of resource-poor farmers. Nature Biotechnology 30, 83-89.

Vitousek, P.M., and Walker, L.R. (1989). Biological Invasion by Myrica faya in Hawaii: Plant Demography, Nitrogen Fixation, Ecosystem Effects. Ecological Monographs 59: 247-265.

Wade, E., Ewel, J., and Hofstetter, R. (1980). Fire in South Florida Ecosystems. U.S. Forest Service Technical Report SE-1. Asheville, North Carolina. Southeastern Forest Research Station. 
Yao, F., Zhang, R., Zhu, Z., Xia, K., Liu, C. (2006). MutScreener: primer design tool for PCR-direct sequencing. Nucleic Acids Res. 34:W660-W664.

Young, J.P., Haukka, K. (1996). Diversity and Phylogeny of Rhizobia. New Phytologist 133, 87-94.

Zahran, H.H. (1999). Rhizobium-Legume Symbiosis and Nitrogen Fixation Under Severe Conditions in Arid Climate. Microbiology and Molecular Biology Reviews 63 (4): 968-989. 


\section{APPENDICES}

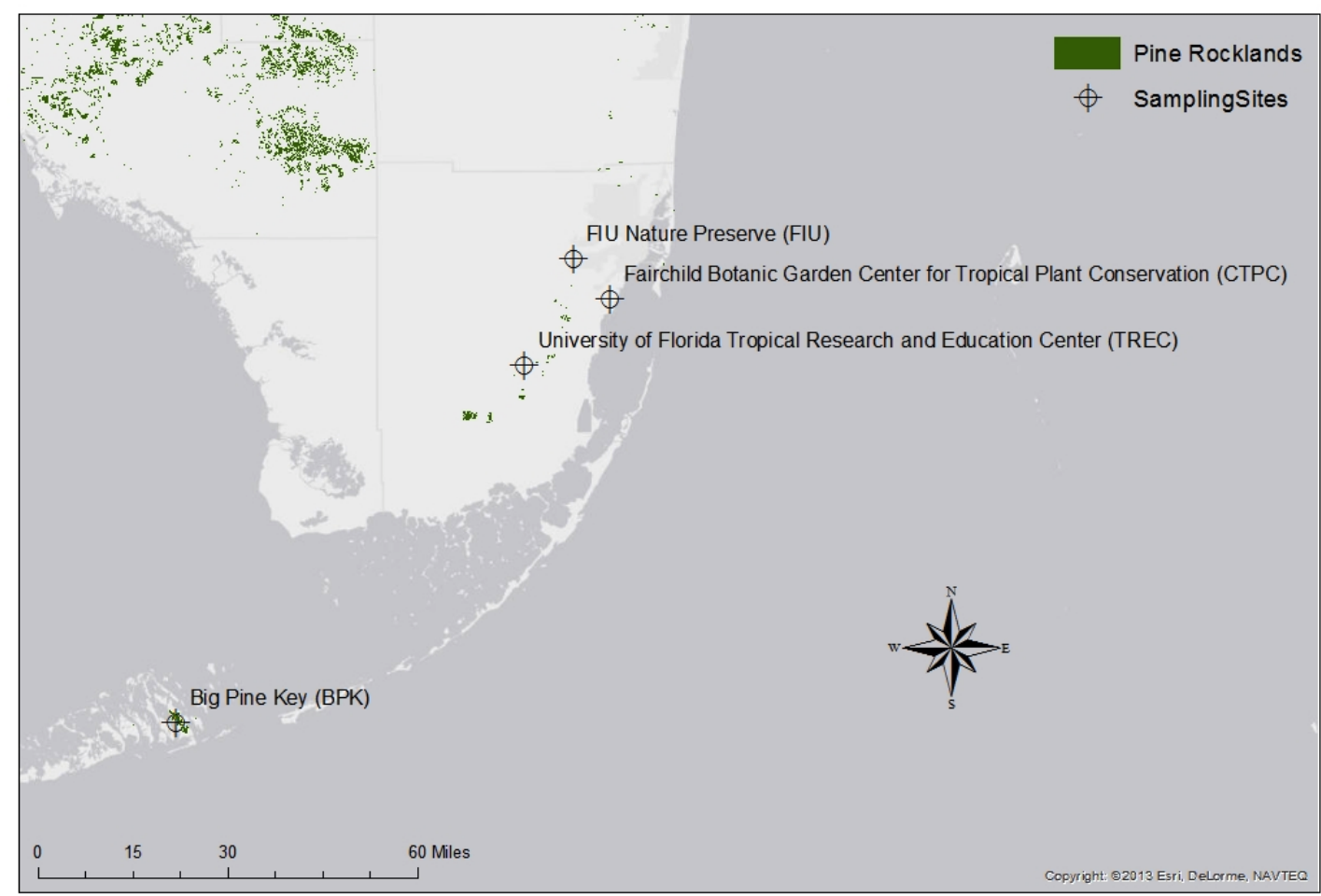

Figure 1. Map of four south Florida pine rockland collection sites. FIU (soil 1), CTPC (soil 2), BPK (soil 3), TREC (soil 4). 


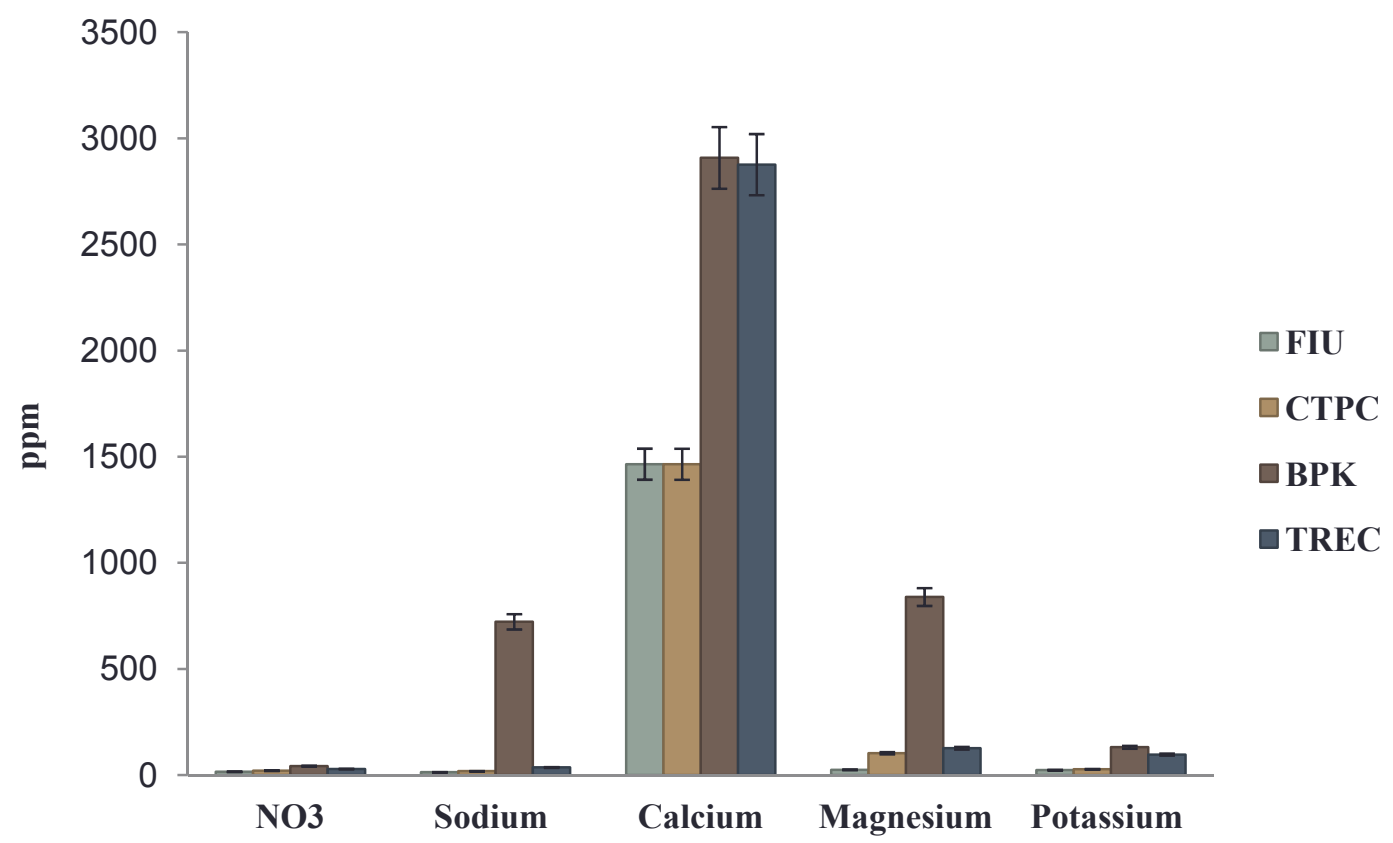

Figure 2. Soil nutrient composition of four pine rockland sites (FIU, BPK, CTPC, and TREC) in parts per million. 


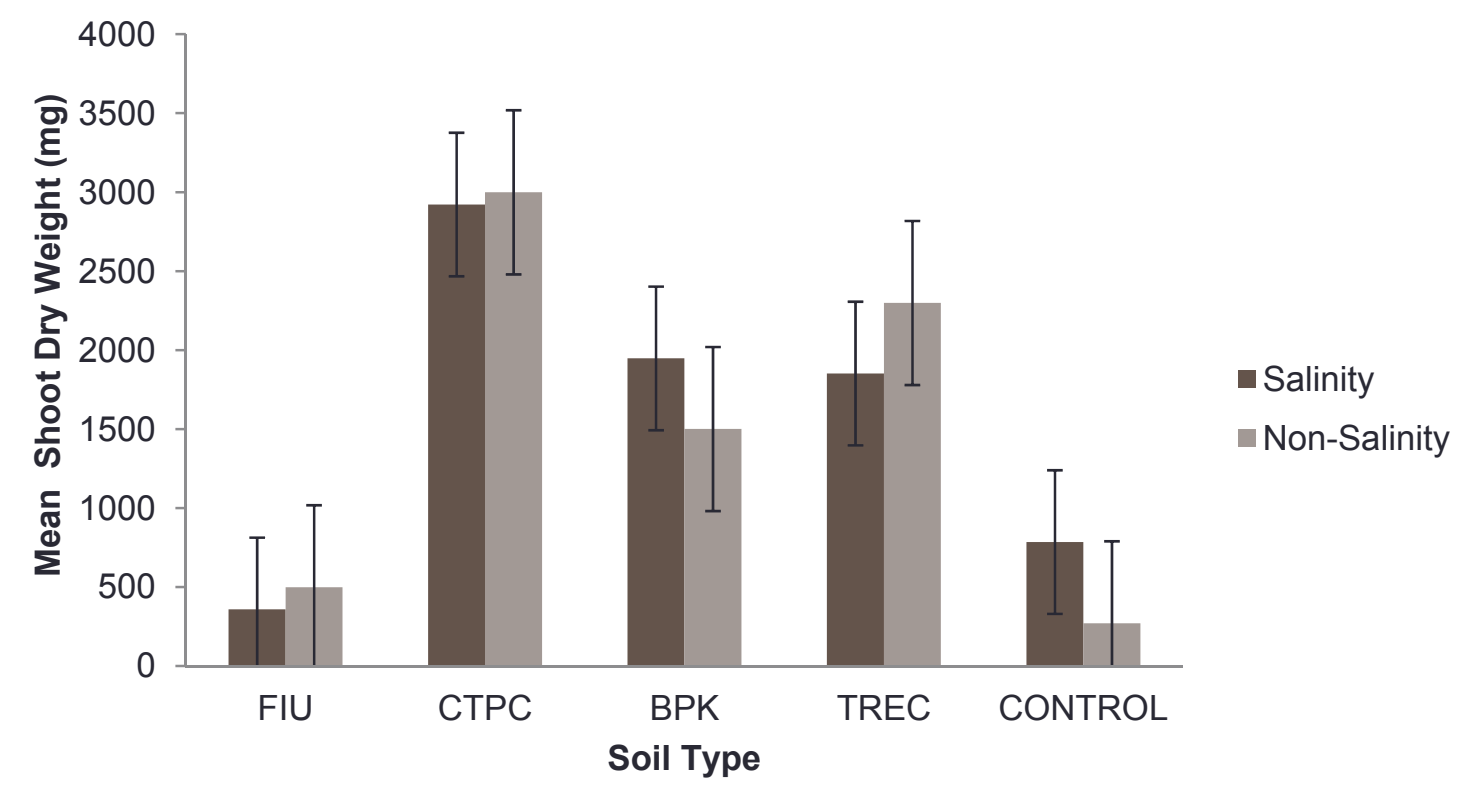

Figure 3a. Cajanus cajan mean shoot dry weight by pine rockland soil type and salinity treatment.

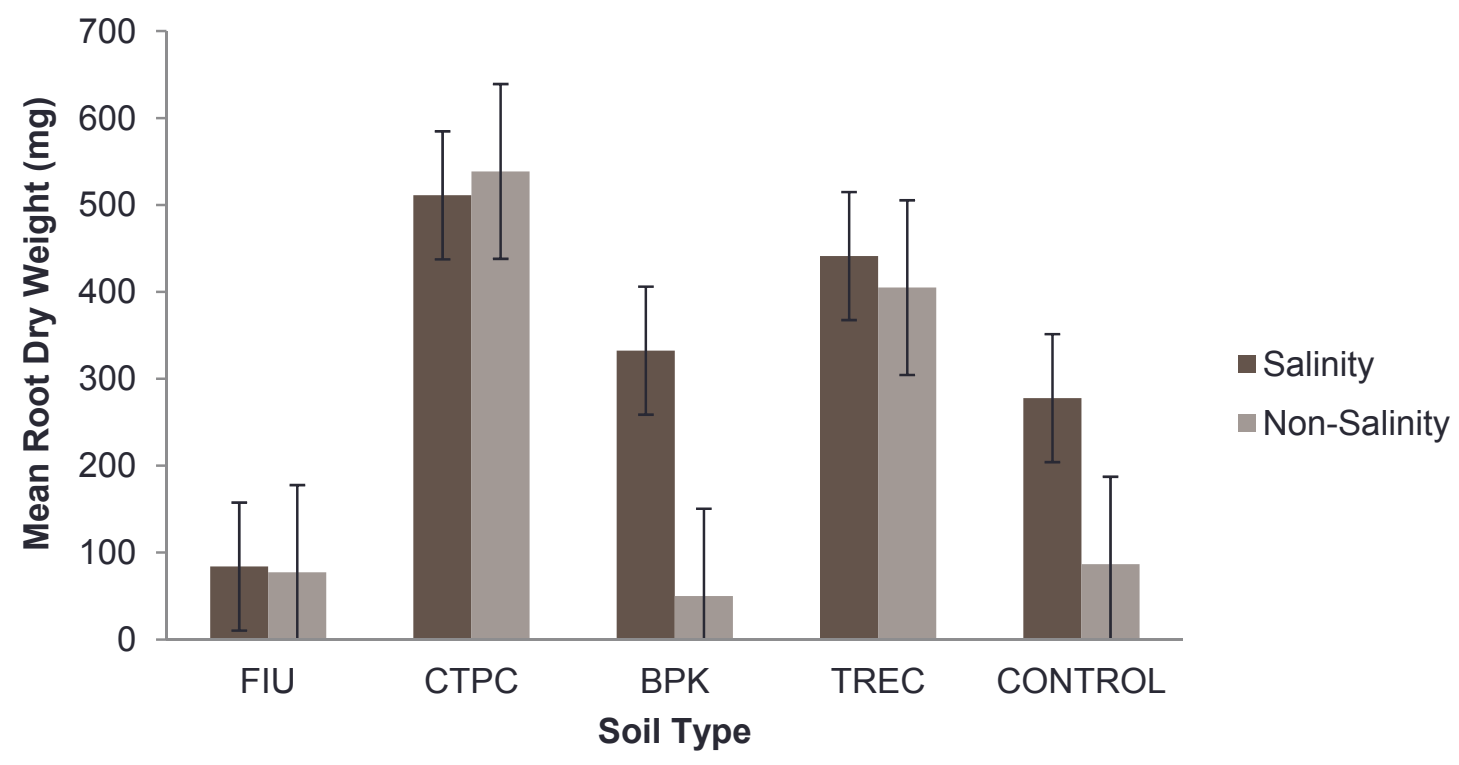

Figure 3b. Cajanus cajan mean root dry weight by pine rockland soil type and salinity treatment. 


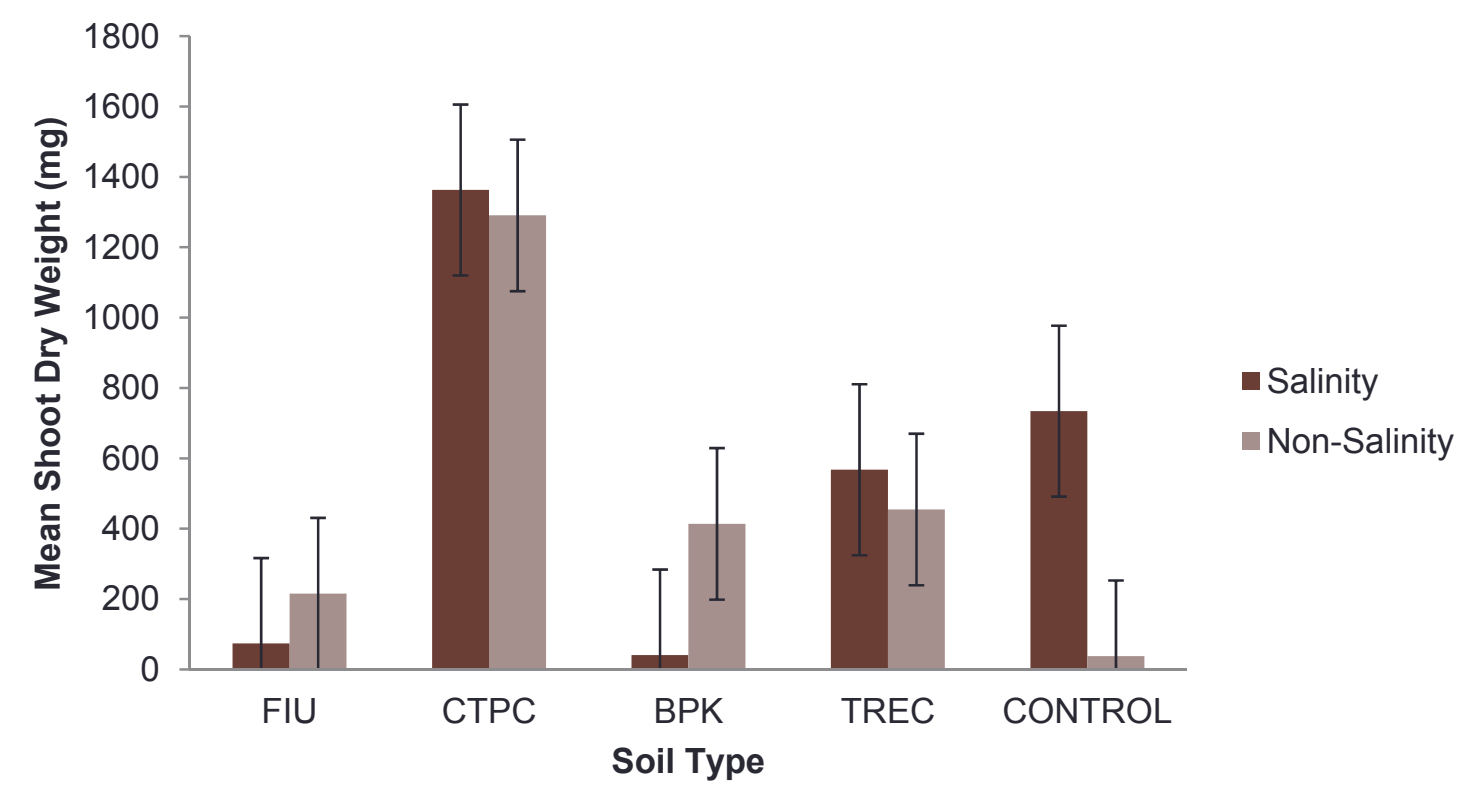

Figure 3c. Chamaecrista fasciculata mean shoot dry weight by pine rockland soil type and salinity treatment.

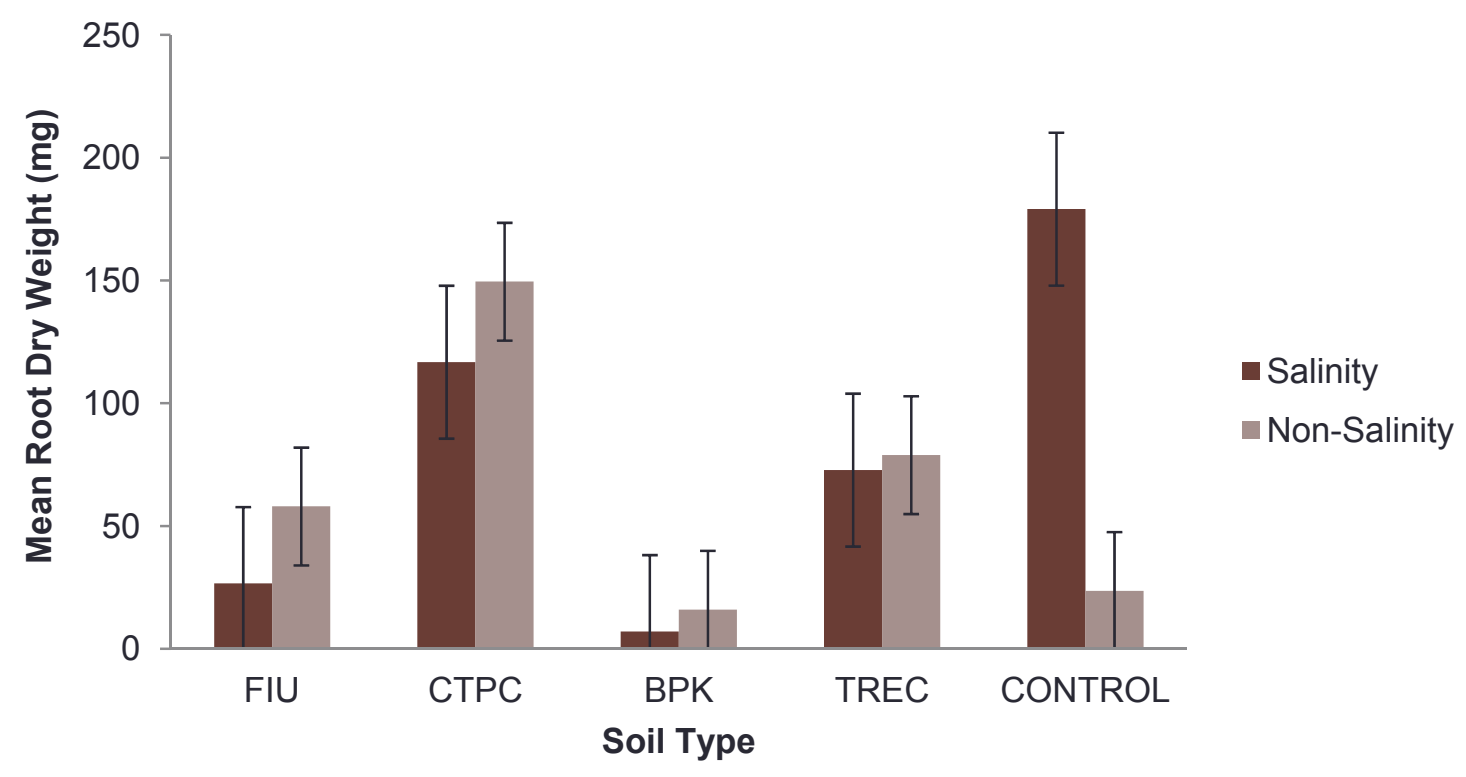

Figure 3d. Chamaecrista fasciculata mean root dry weight by pine rockland soil type and salinity treatment. 


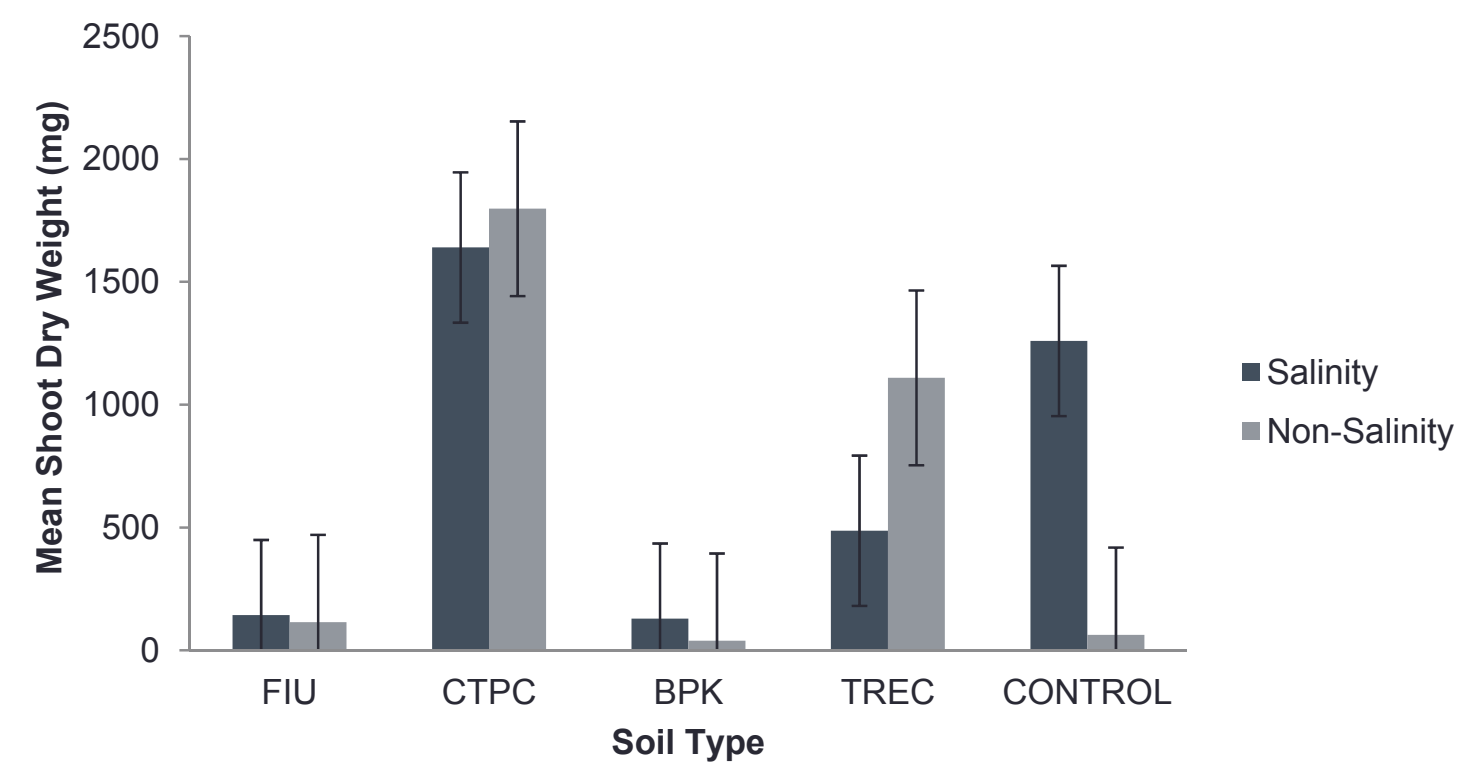

Figure 3e. Tephrosia angustissima mean shoot dry weight by pine rockland soil type and salinity treatment.

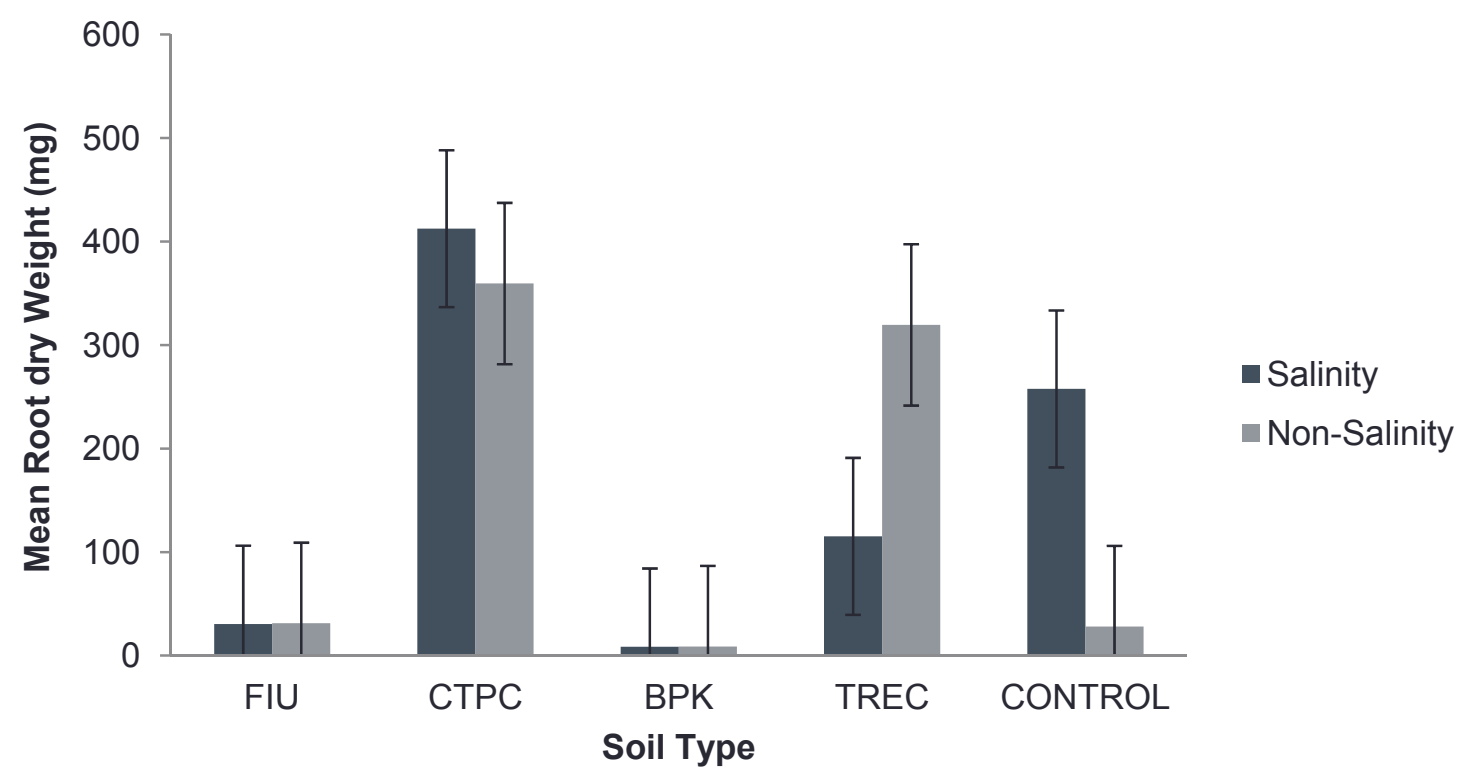

Figure 3f. Tephrosia angustissima mean root dry weight by pine rockland soil type and salinity treatment. 


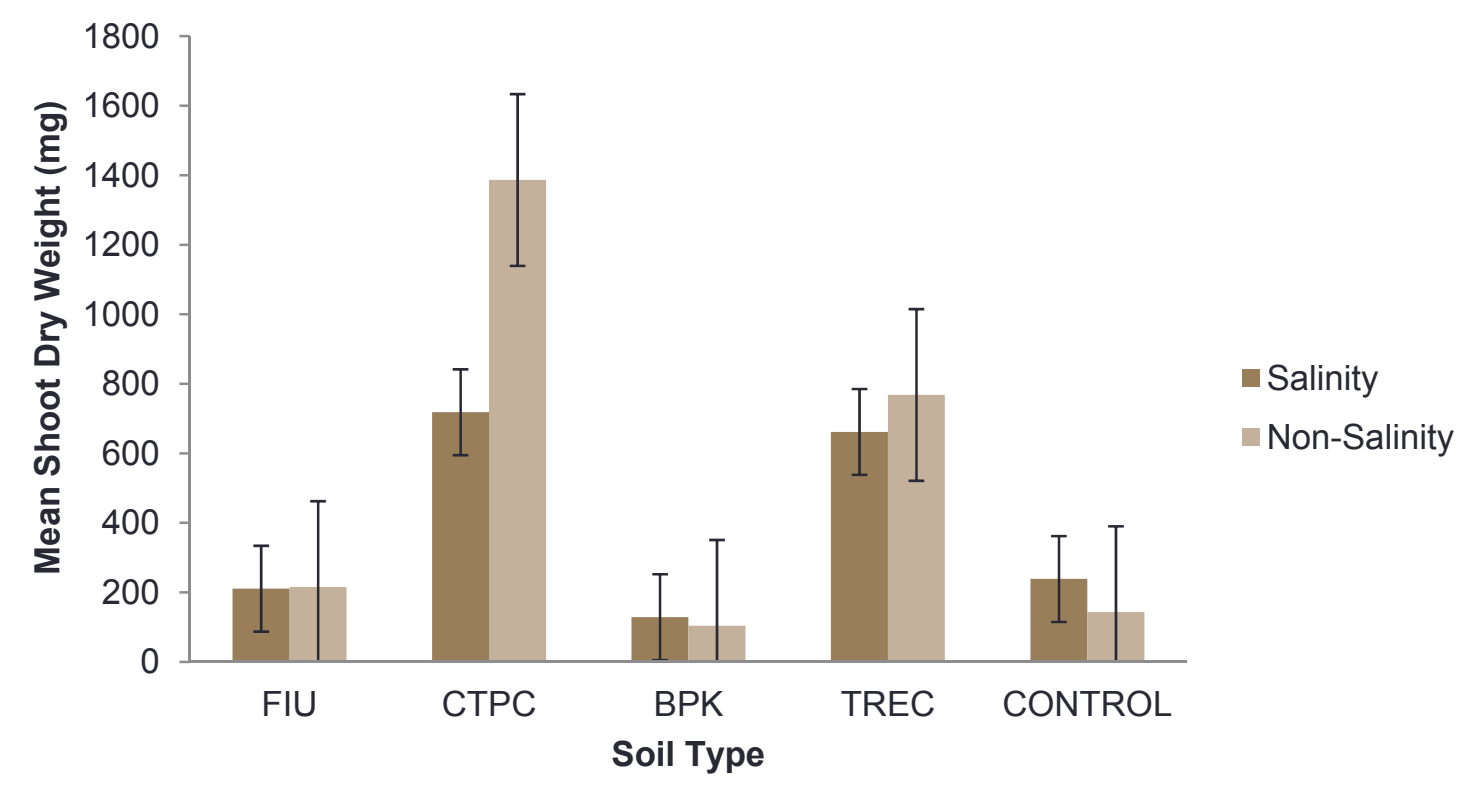

Figure 3g. Abrus precatorious mean shoot dry weight by pine rockland soil type and salinity treatment.

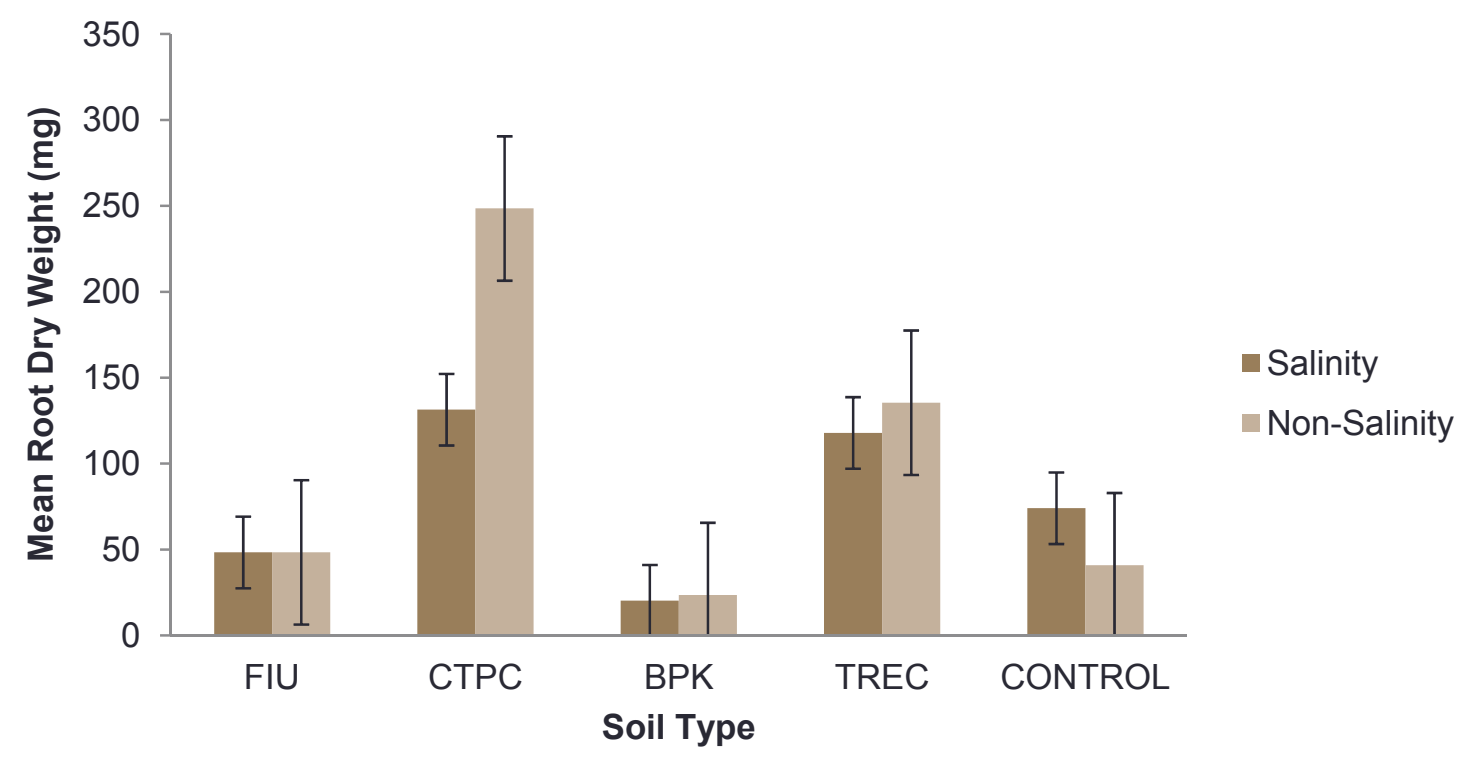

Figure 3h. Abrus precatorious mean root dry weight by pine rockland soil type and salinity treatment. 


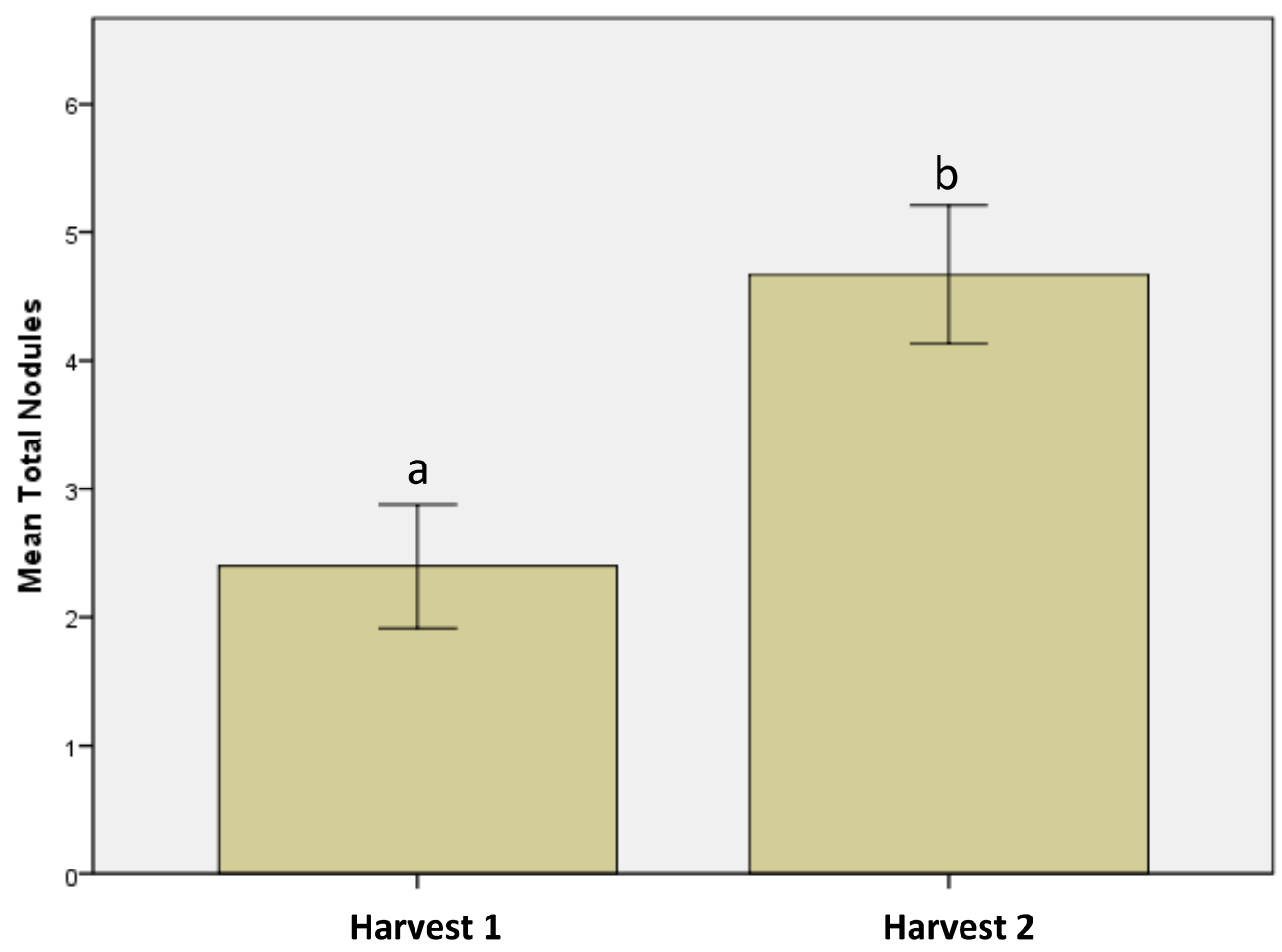


Table 1. Mean nodulation of host legume species by soil type in Harvest 1. Sites with the same letter do not differ significantly form each other $(\mathrm{p}<0.05)$.

Harvest 1

\begin{tabular}{lccc}
\hline a & Cajanus cajan & & \\
\hline Soil Type & Mean & $\begin{array}{c}\text { Standard } \\
\text { Deviation }\end{array}$ & Total n \\
FIU & $0.00^{\mathrm{ab}}$ & 0.00 & 3 \\
CTPC & $9.00^{\mathrm{b}}$ & - & 1 \\
BPK & $0.00^{\mathrm{ab}}$ & 0.00 & 2 \\
TREC & - & - & - \\
CONTROL & $0.00^{\mathrm{a}}$ & 0.00 & 4 \\
\hline
\end{tabular}

\begin{tabular}{|c|c|c|c|}
\hline b & \multicolumn{3}{|c|}{ Chamaecrista fasciculata } \\
\hline Soil Type & Mean & $\begin{array}{l}\text { Standard } \\
\text { Deviation }\end{array}$ & Total n \\
\hline FIU & - & - & - \\
\hline СТРС & $7.25^{\mathrm{a}}$ & 6.62 & 4 \\
\hline $\mathrm{BPK}$ & $3.00^{\mathrm{a}}$ & - & 1 \\
\hline TREC & $5.50^{\mathrm{a}}$ & 2.12 & 2 \\
\hline CONTROL & $0.00^{\mathrm{b}}$ & 0.00 & 4 \\
\hline c & \multicolumn{3}{|c|}{ Tephrosia angustissima } \\
\hline Soil Type & Mean & $\begin{array}{l}\text { Standard } \\
\text { Deviation }\end{array}$ & Total n \\
\hline FIU & $0.00^{\mathrm{a}}$ & 0.00 & 2 \\
\hline СТРC & $2.00^{\mathrm{ab}}$ & 3.46 & 3 \\
\hline BPK & $0.00^{\mathrm{b}}$ & 0.00 & 5 \\
\hline TREC & $6.60^{\mathrm{a}}$ & 5.08 & 5 \\
\hline CONTROL & $0.00^{\mathrm{b}}$ & 0.00 & 5 \\
\hline d & \multicolumn{3}{|c|}{ Abrus precatorious } \\
\hline Soil Type & Mean & $\begin{array}{l}\text { Standard } \\
\text { Deviation }\end{array}$ & Total n \\
\hline FIU & $0.00^{\mathrm{a}}$ & 0.00 & 6 \\
\hline СТРC & $7.43^{\mathrm{b}}$ & 3.69 & 7 \\
\hline BPK & $0.00^{\mathrm{a}}$ & 0.00 & 4 \\
\hline TREC & $5.00^{\mathrm{b}}$ & 4.55 & 4 \\
\hline CONTROL & $0.00^{\mathrm{a}}$ & 0.00 & 6 \\
\hline
\end{tabular}


Table 2. Mean nodulation of host legume species by soil type in Harvest 2. Sites with the same letter do not differ significantly form each other $(\mathrm{p}<0.05)$.

\section{Harvest 2}

\begin{tabular}{lccc}
\hline a & Cajanus cajan & & \\
\hline Soil Type & Mean & $\begin{array}{c}\text { Standard } \\
\text { Deviation }\end{array}$ & Total n \\
FIU & $0.40^{\mathrm{a}}$ & 0.89 & 5 \\
CTPC & $12.00^{\mathrm{b}}$ & 0.00 & 6 \\
BPK & $2.67^{\mathrm{a}}$ & 3.79 & 3 \\
TREC & $11.25^{\mathrm{b}}$ & 1.50 & 4 \\
CONTROL & $0.60^{\mathrm{a}}$ & 0.55 & 5 \\
\hline
\end{tabular}

\begin{tabular}{lccc}
\hline b & Chamaecrista fasciculata & \\
\hline Soil Type & Mean & $\begin{array}{c}\text { Standard } \\
\text { Deviation }\end{array}$ & Total n \\
FIU & $1.00^{\text {a }}$ & 1.41 & 4 \\
CTPC & $9.40^{\text {a }}$ & 5.27 & 5 \\
BPK & $0.00^{\text {a }}$ & - & 1 \\
TREC & $10.33^{\text {a }}$ & 2.89 & 3 \\
CONTROL & $4.00^{\text {a }}$ & 6.93 & 3 \\
\hline
\end{tabular}

\begin{tabular}{|c|c|c|c|}
\hline c & \multicolumn{3}{|c|}{ Tephrosia angustissima } \\
\hline Soil Type & Mean & $\begin{array}{l}\text { Standard } \\
\text { Deviation }\end{array}$ & Total n \\
\hline FIU & $0.00^{\mathrm{a}}$ & 0.00 & 6 \\
\hline СТРC & $10.00^{b}$ & 4.90 & 6 \\
\hline BPK & $0.00^{\mathrm{a}}$ & 0.00 & 3 \\
\hline TREC & $9.50^{\mathrm{b}}$ & 3.02 & 6 \\
\hline CONTROL & $3.25^{\mathrm{ab}}$ & 5.85 & 4 \\
\hline d & \multicolumn{3}{|c|}{ Abrus precatorious } \\
\hline Soil Type & Mean & $\begin{array}{l}\text { Standard } \\
\text { Deviation }\end{array}$ & Total n \\
\hline FIU & $0.00^{\mathrm{a}}$ & 0.00 & 9 \\
\hline СТPC & $6.25^{\mathrm{b}}$ & 5.06 & 8 \\
\hline BPK & $0.00^{\mathrm{a}}$ & 0.00 & 7 \\
\hline TREC & $7.88^{b}$ & 4.26 & 8 \\
\hline CONTROL & $0.00^{\mathrm{a}}$ & 0.00 & 4 \\
\hline
\end{tabular}




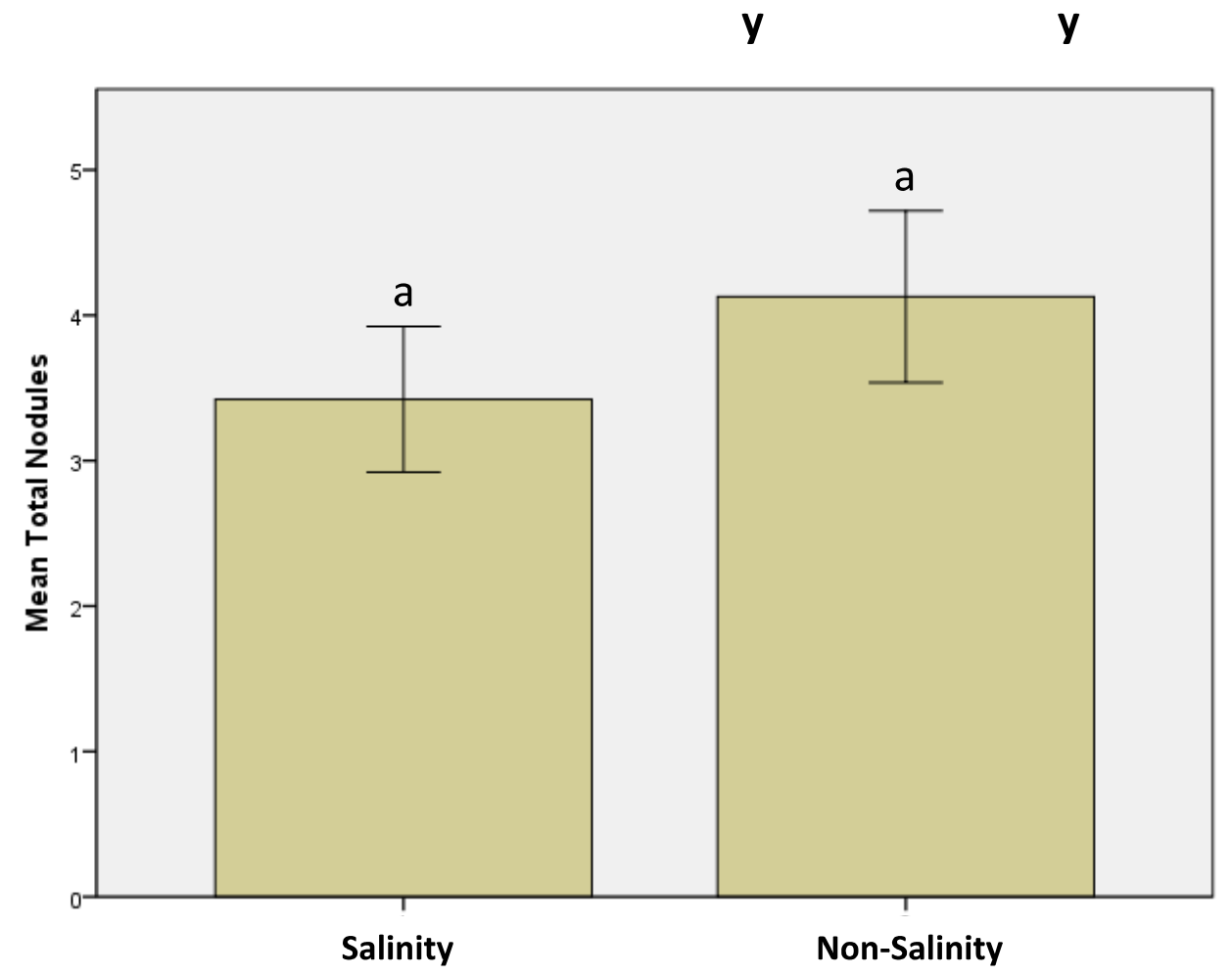


Table 3. Mean nodulation in salinity and no-salinity per soil type and legume species. Sites with the same letter do not differ significantly form each other $(\mathrm{p}<0.05)$.

\begin{tabular}{lcccccc}
\hline a & \multicolumn{5}{c}{ Cajanus cajan } \\
Soil Type & Mean & $\begin{array}{c}\text { Standard } \\
\text { Deviation }\end{array}$ & Total $\mathbf{n}$ & Mean & $\begin{array}{c}\text { Standard } \\
\text { Deviation }\end{array}$ & Total n \\
FIU & $0.33^{\text {a }}$ & 0.82 & 6.00 & 0.00 & 0.00 & 2.00 \\
CTPC & $11.25^{\text {a }}$ & 1.50 & 4.00 & 12.00 & 0.00 & 3.00 \\
BPK & $3.50^{\text {a }}$ & 4.95 & 2.00 & 0.33 & 0.58 & 3.00 \\
TREC & $12.00^{\text {a }}$ & 0.00 & 2.00 & 10.50 & 2.12 & 2.00 \\
CONTROL & $0.20^{\text {a }}$ & 0.45 & 5.00 & 0.50 & 0.58 & 4.00 \\
\hline
\end{tabular}

\begin{tabular}{lcccccc}
\hline \multicolumn{7}{c}{ Chamaecrista fasciculata } \\
b & \multicolumn{7}{c}{ Salinity } & \multicolumn{3}{c}{ Non-Salinity } \\
\hline Soil Type & Mean & $\begin{array}{c}\text { Standard } \\
\text { Deviation }\end{array}$ & Total n & Mean & $\begin{array}{c}\text { Standard } \\
\text { Deviation }\end{array}$ & Total n \\
FIU & $0.33^{\text {a }}$ & 0.58 & 3.00 & 3.00 & $\cdot$ & 1.00 \\
CTPC & $7.20^{\text {a }}$ & 6.14 & 5.00 & 10.00 & 4.00 & 4.00 \\
BPK & $3.00^{\text {a }}$ &. & 1.00 & 0.00 &. & 1.00 \\
TREC & $7.67^{\text {a }}$ & 4.04 & 3.00 & 9.50 & 3.54 & 2.00 \\
CONTROL & $2.40^{\text {a }}$ & 5.37 & 5.00 & 0.00 & 0.00 & 2.00 \\
\hline
\end{tabular}

\begin{tabular}{|c|c|c|c|c|c|c|}
\hline \multirow[b]{2}{*}{ c } & \multicolumn{6}{|c|}{ Tephrosia angustissima } \\
\hline & & Salinity & & & Non-Salinity & \\
\hline Soil Type & Mean & $\begin{array}{l}\text { Standard } \\
\text { Deviation }\end{array}$ & Total n & Mean & $\begin{array}{l}\text { Standard } \\
\text { Deviation }\end{array}$ & Total $n$ \\
\hline FIU & $0.00^{\mathrm{a}}$ & 0.00 & 4.00 & 0.00 & 0.00 & 4.00 \\
\hline СТРC & $6.00^{\mathrm{a}}$ & 6.93 & 4.00 & 8.40 & 5.37 & 5.00 \\
\hline BPK & $0.00^{\mathrm{a}}$ & 0.00 & 4.00 & 0.00 & 0.00 & 4.00 \\
\hline TREC & $5.50^{\mathrm{a}}$ & 3.73 & 6.00 & 11.40 & 1.34 & 5.00 \\
\hline CONTROL & $2.60^{\mathrm{a}}$ & 5.27 & 5.00 & 0.00 & 0.00 & 4.00 \\
\hline
\end{tabular}

\begin{tabular}{lcccccc}
\hline d & \multicolumn{5}{c}{ Abrus precatorious } \\
Soil Type & Mean & $\begin{array}{c}\text { Standard } \\
\text { Deviation }\end{array}$ & Total n & Mean & $\begin{array}{c}\text { Standard } \\
\text { Deviation }\end{array}$ & Total n \\
FIU & $0.00^{\text {a }}$ & 0.00 & 7.00 & 0.00 & 0.00 & 8.00 \\
CTPC & $6.50^{\text {a }}$ & 4.17 & 8.00 & 7.14 & 4.88 & 7.00 \\
BPK & $0.00^{\text {a }}$ & 0.00 & 5.00 & 0.00 & 0.00 & 6.00 \\
TREC & $6.40^{\text {a }}$ & 4.72 & 5.00 & 7.29 & 4.46 & 7.00 \\
CONTROL & $0.00^{\text {a }}$ & 0.00 & 6.00 & 0.00 & 0.00 & 4.00 \\
\hline
\end{tabular}


Table 4. Analysis of variance (ANOVA) with salt treatment, soil, and salt x soil as predictor variables. F-values are listed, with numerator and denominator degrees of freedom in parentheses. * indicates $\mathrm{P}<0.05$, ** $\mathrm{P}<0.01$, *** $\mathrm{P}<0.001$, and **** $\mathrm{P}<$ 0.0001. All tests performed in SAS 9.3 with PROC GLM and Type III sum of squares. $\mathrm{N} / \mathrm{E}$ non estimable values given the low sample size.

\begin{tabular}{|c|c|c|c|c|c|c|}
\hline $\mathbf{a}$ & Factor & $\begin{array}{c}\text { Shoot Dry } \\
\text { Weight }\end{array}$ & $\begin{array}{c}\text { Root Dry } \\
\text { Weight }\end{array}$ & Growth & Nodules & Total N \\
\hline \multirow[t]{3}{*}{ Cajanus cajan } & Salt & $(1,4) 1.52$ & $(1,4) 0.67$ & $(1,4) 0.2$ & $\mathrm{~N} / \mathrm{E}$ & $(1,2) 9.41$ \\
\hline & Soil & $(3,4) 1.62$ & $(3,4) 0.57$ & $(3,4) 1.22$ & $\mathrm{~N} / \mathrm{E}$ & ${ }_{(3,2)} 7.58$ \\
\hline & Salt x Soil & $(1,4) 2.91$ & ${ }_{(1,4)} 0.49$ & ${ }_{(1,4)} 0.11$ & $\mathrm{~N} / \mathrm{E}$ & $\mathrm{N} / \mathrm{E}$ \\
\hline \multirow[t]{3}{*}{ Chamaecrista fasciculata } & Salt & $(1,4) 0.42$ & ${ }_{(1,4)} 0$ & ${ }_{(1,4)} 0.14$ & $(1,4) 0.2$ & $(1,2) 1.26$ \\
\hline & Soil & $(3,4) 3.18$ & $(3,4) 0.36$ & ${ }_{(3,4)} 0.25$ & $(3,4) 1.34$ & ${ }_{(1,2)} 136.1$ \\
\hline & Salt x Soil & $(2,4) 0.81$ & $(2,4) 0.09$ & $(2,4) 0.43$ & ${ }_{(2,4)} 0.06$ & $\mathrm{~N} / \mathrm{E}$ \\
\hline \multirow[t]{3}{*}{ Tephrosia angustissima } & Salt & $\mathrm{N} / \mathrm{E}$ & $\mathrm{N} / \mathrm{E}$ & $\mathrm{N} / \mathrm{E}$ & $\mathrm{N} / \mathrm{E}$ & $\mathrm{N} / \mathrm{E}$ \\
\hline & Soil & $(2,4) 1.96$ & $(2,4) 0.83$ & $(2,4) 8.44^{*}$ & $(2,4) 1.43$ & $(1,1) 0.47$ \\
\hline & Salt x Soil & $\mathrm{N} / \mathrm{E}$ & $\mathrm{N} / \mathrm{E}$ & $\mathrm{N} / \mathrm{E}$ & $\mathrm{N} / \mathrm{E}$ & $\mathrm{N} / \mathrm{E}$ \\
\hline \multirow[t]{3}{*}{ Abrus precatorious } & Salt & ${ }_{(1,17)} 0.01$ & $(1,17) 0.24$ & $(1,17) 2.23$ & ${ }_{(1,17)} 0.41$ & $(1,8) 2.69$ \\
\hline & Soil & $(4,17) 4.68$ & $(4,17) 1.86$ & $(4,17) 2.26$ & $(4,17) 8.59$ & $(4,8) 0.84$ \\
\hline & Salt x Soil & $(4,17) 1.03$ & $(4,17) 2.04$ & $(4,17) 3.06^{*}$ & ${ }_{(4,17)} 0.35$ & ${ }_{(1,8)} 2.53$ \\
\hline
\end{tabular}

\begin{tabular}{|c|c|c|c|c|c|c|}
\hline $\mathbf{b}$ & Factor & $\begin{array}{c}\text { Shoot Dry } \\
\text { Weight }\end{array}$ & $\begin{array}{c}\text { Root Dry } \\
\text { Weight }\end{array}$ & Growth & Nodules & Total N \\
\hline \multirow[t]{3}{*}{ Cajanus cajan } & Salt & ${ }_{(1,13)} 2.5$ & $(1,13) 6.84^{*}$ & ${ }_{(1,13)} 0.31$ & $(1,13) 20.66$ & $(1,4) 25.08$ \\
\hline & Soil & $(4,13) 14.84^{* * * *}$ & $(4,13) 8.62^{* * * *}$ & $(4,13)^{5.06^{*}}$ & $(4,13) 245.81^{* * * *}$ & ${ }_{(3,4)} 0.26$ \\
\hline & Salt x Soil & $(4,13) 0.89$ & $(4,13) 1.57$ & $(4,13) 0.34$ & $(4,13) 9.89$ & ${ }_{(1,4)} 0.83$ \\
\hline \multirow[t]{3}{*}{ Chamaecrista fasciculata } & Salt & $(1,7) 0.12$ & $(1,7) 0.21$ & $(1,6)^{2.68}$ & $(1,7) 0.1$ & $\mathrm{~N} / \mathrm{E}$ \\
\hline & Soil & $(4,7) 0.56$ & $(1,7) 0.25$ & $(4,6)^{5.69^{*}}$ & $(1,7) 2.54$ & $\mathrm{~N} / \mathrm{E}$ \\
\hline & Salt x Soil & $(3,7) 0.37$ & ${ }_{(1,7)} 0.64$ & $(3,6)^{4.93^{*}}$ & $(1,7) 0.66$ & $\mathrm{~N} / \mathrm{E}$ \\
\hline \multirow[t]{3}{*}{ Tephrosia angustissima } & Salt & $\mathrm{N} / \mathrm{E}$ & $\mathrm{N} / \mathrm{E}$ & $\mathrm{N} / \mathrm{E}$ & $\mathrm{N} / \mathrm{E}$ & $\mathrm{N} / \mathrm{E}$ \\
\hline & Soil & $(1,1) 0.18$ & ${ }_{(1,1)} 0$ & $(1,1) 0.06$ & $\mathrm{~N} / \mathrm{E}$ & $\mathrm{N} / \mathrm{E}$ \\
\hline & Salt $\mathrm{x}$ Soil & $\mathrm{N} / \mathrm{E}$ & $\mathrm{N} / \mathrm{E}$ & $\mathrm{N} / \mathrm{E}$ & $\mathrm{N} / \mathrm{E}$ & $\mathrm{N} / \mathrm{E}$ \\
\hline \multirow[t]{3}{*}{ Abrus precatorious } & Salt & ${ }_{(1,26)} 0.65$ & ${ }_{(1,26)} 0.31$ & ${ }_{(1,26)} 0.54$ & ${ }_{(1,26)} 0.13$ & $\mathrm{~N} / \mathrm{E}$ \\
\hline & Soil & $(4,26) 4.08^{*}$ & $(4,26) 3.68^{*}$ & $(4,26) 15.39^{* * * *}$ & $(4,26) 9.53^{* * * *}$ & $\mathrm{~N} / \mathrm{E}$ \\
\hline & Salt $x$ Soil & $(4,26) 0.57$ & $(4,26) 0.23$ & $(4,26) 5.37$ & $(4,26) 0.07$ & $\mathrm{~N} / \mathrm{E}$ \\
\hline
\end{tabular}


Table 5. Correlation among plant performance measurements and nodulation by plant host species in harvest 1. Pearson's r, P-value, and the number of samples (n) are shown for each character combination. N/E non estimable values given the low sample size.

Harvest 1-No-salinity Cajanus cajan

\begin{tabular}{|c|c|c|c|c|c|c|}
\hline $\mathbf{a}$ & & $\begin{array}{c}\text { Dry Shoot } \\
\text { Weight }\end{array}$ & $\begin{array}{c}\text { Dry Root } \\
\text { Weight }\end{array}$ & Growth & Total N & Nodules \\
\hline \multirow[t]{3}{*}{ Dry Shoot Weight } & $\mathbf{r}$ & 1 & 0.98085 & 0.99249 & $\mathrm{~N} / \mathrm{E}$ & $\mathrm{N} / \mathrm{E}$ \\
\hline & $\mathbf{p}$ & 0.1248 & 0.0781 & $\mathrm{~N} / \mathrm{E}$ & $\mathrm{N} / \mathrm{E}$ & $\mathrm{N} / \mathrm{E}$ \\
\hline & $\mathbf{n}$ & 3 & 3 & 3 & 1 & 3 \\
\hline \multirow[t]{3}{*}{ Dry Root Weight } & $\mathbf{r}$ & 0.98085 & 1 & 0.99731 & $\mathrm{~N} / \mathrm{E}$ & $\mathrm{N} / \mathrm{E}$ \\
\hline & $\mathbf{p}$ & 0.1248 & 0.0467 & $\mathrm{~N} / \mathrm{E}$ & $\mathrm{N} / \mathrm{E}$ & $\mathrm{N} / \mathrm{E}$ \\
\hline & $\mathbf{n}$ & 3 & 3 & 3 & 1 & 3 \\
\hline \multirow[t]{3}{*}{ Growth } & $\mathbf{r}$ & 0.99249 & 0.99731 & 1 & $\mathrm{~N} / \mathrm{E}$ & $\mathrm{N} / \mathrm{E}$ \\
\hline & $\mathbf{p}$ & 0.0781 & 0.0467 & $\mathrm{~N} / \mathrm{E}$ & $\mathrm{N} / \mathrm{E}$ & $\mathrm{N} / \mathrm{E}$ \\
\hline & $\mathbf{n}$ & 3 & 3 & 3 & 1 & 3 \\
\hline \multirow[t]{3}{*}{ Total N } & $\mathbf{r}$ & $\mathrm{N} / \mathrm{E}$ & $\mathrm{N} / \mathrm{E}$ & $\mathrm{N} / \mathrm{E}$ & $\mathrm{N} / \mathrm{E}$ & $\mathrm{N} / \mathrm{E}$ \\
\hline & $\mathbf{p}$ & $\mathrm{N} / \mathrm{E}$ & $\mathrm{N} / \mathrm{E}$ & $\mathrm{N} / \mathrm{E}$ & $\mathrm{N} / \mathrm{E}$ & $\mathrm{N} / \mathrm{E}$ \\
\hline & $\mathbf{n}$ & 1 & 1 & 1 & 1 & 1 \\
\hline \multirow[t]{3}{*}{ Nodules } & $\mathbf{r}$ & $\mathrm{N} / \mathrm{E}$ & $\mathrm{N} / \mathrm{E}$ & $\mathrm{N} / \mathrm{E}$ & $\mathrm{N} / \mathrm{E}$ & $\mathrm{N} / \mathrm{E}$ \\
\hline & $\mathbf{p}$ & $\mathrm{N} / \mathrm{E}$ & $\mathrm{N} / \mathrm{E}$ & $\mathrm{N} / \mathrm{E}$ & $\mathrm{N} / \mathrm{E}$ & $\mathrm{N} / \mathrm{E}$ \\
\hline & $\mathbf{n}$ & 3 & 3 & 3 & 1 & 3 \\
\hline
\end{tabular}

Harvest 1- Salinity Cajanus cajan

\begin{tabular}{lcccccc}
\hline b & & $\begin{array}{c}\text { Dry Shoot } \\
\text { Weight }\end{array}$ & $\begin{array}{c}\text { Dry Root } \\
\text { Weight }\end{array}$ & Growth & Total N & Nodules \\
\hline Dry Shoot Weight & r & 1 & -0.08625 & 0.48882 & 0.1443 & 0.73097 \\
& p & 0.8541 & 0.2656 & 0.7851 & 0.062 & 0.062 \\
Dry Root Weight & n & 7 & 7 & 7 & 6 & 7 \\
& r & -0.08625 & 1 & 0.46323 & -0.36008 & -0.13864 \\
Growth & $\mathbf{p}$ & 0.8541 & 0.2952 & 0.4832 & 0.7669 & 0.7669 \\
& $\mathbf{n}$ & 7 & 7 & 7 & 6 & 7 \\
Total N & $\mathbf{r}$ & 0.48882 & 0.46323 & 1 & 0.42678 & 0.73389 \\
& $\mathbf{p}$ & 0.2656 & 0.2952 & 0.3987 & 0.0604 & 0.0604 \\
& $\mathbf{n}$ & 7 & 7 & 7 & 6 & 7 \\
Nodules & $\mathbf{r}$ & 0.1443 & -0.36008 & 0.42678 & 1 & 0.54573 \\
& $\mathbf{p}$ & 0.7851 & 0.4832 & 0.3987 & 0.2627 & 0.2627 \\
& $\mathbf{n}$ & 6 & 6 & 6 & 6 & 6 \\
\hline
\end{tabular}




\begin{tabular}{|c|c|c|c|c|c|c|}
\hline c & & Dry Shoot Weight & $\begin{array}{c}\text { Dry Root } \\
\text { Weight }\end{array}$ & Growth & Total N & Nodules \\
\hline \multirow[t]{3}{*}{ Dry Shoot Weight } & $\mathbf{r}$ & 1 & 0.93056 & 0.69296 & -0.53345 & 0.9137 \\
\hline & $\mathbf{p}$ & 0.0694 & 0.307 & 0.6418 & 0.0863 & 0.0702 \\
\hline & $\mathbf{n}$ & 4 & 4 & 4 & 3 & 4 \\
\hline \multirow[t]{3}{*}{ Dry Root Weight } & $\mathbf{r}$ & 0.93056 & 1 & 0.81687 & -0.31705 & 0.79409 \\
\hline & $\mathbf{p}$ & 0.0694 & 0.1831 & 0.7946 & 0.2059 & 0.2401 \\
\hline & $\mathbf{n}$ & 4 & 4 & 4 & 3 & 4 \\
\hline \multirow[t]{3}{*}{ Growth } & $\mathbf{r}$ & 0.69296 & 0.81687 & 1 & 0.29919 & 0.76687 \\
\hline & $\mathbf{p}$ & 0.307 & 0.1831 & 0.8066 & 0.2331 & 0.6165 \\
\hline & $\mathbf{n}$ & 4 & 4 & 4 & 3 & 4 \\
\hline \multirow[t]{3}{*}{ Total N } & $\mathbf{r}$ & -0.53345 & -0.31705 & 0.29919 & 1 & -0.25907 \\
\hline & $\mathbf{p}$ & 0.6418 & 0.7946 & 0.8066 & 0.8332 & 0.3647 \\
\hline & $\mathbf{n}$ & 3 & 3 & 3 & 3 & 3 \\
\hline \multirow[t]{3}{*}{ Nodules } & $\mathbf{r}$ & 0.9137 & 0.79409 & 0.76687 & -0.25907 & 1 \\
\hline & $\mathbf{p}$ & 0.0863 & 0.2059 & 0.2331 & 0.8332 & 0.1928 \\
\hline & $\mathbf{n}$ & 4 & 4 & 4 & 3 & 4 \\
\hline
\end{tabular}

\begin{tabular}{|c|c|c|c|c|c|c|}
\hline d & & $\begin{array}{c}\text { Dry Shoot } \\
\text { Weight }\end{array}$ & $\begin{array}{c}\text { Dry Root } \\
\text { Weight }\end{array}$ & Growth & Total N & Nodules \\
\hline \multirow[t]{3}{*}{ Dry Shoot Weight } & $\mathbf{r}$ & 1 & 0.84106 & 0.79913 & -1 & 0.27056 \\
\hline & $\mathbf{p}$ & 0.0177 & 0.0311 & $\mathrm{~N} / \mathrm{E}$ & 0.5573 & 0.5511 \\
\hline & $\mathbf{n}$ & 7 & 7 & 7 & 2 & 7 \\
\hline \multirow[t]{3}{*}{ Dry Root Weight } & $\mathbf{r}$ & 0.84106 & 1 & 0.97866 & -1 & -0.26672 \\
\hline & $\mathbf{p}$ & 0.0177 & 0.0001 & $\mathrm{~N} / \mathrm{E}$ & 0.5631 & 0.5457 \\
\hline & $\mathbf{n}$ & 7 & 7 & 7 & 2 & 7 \\
\hline \multirow[t]{3}{*}{ Growth } & $\mathbf{r}$ & 0.79913 & 0.97866 & 1 & -1 & -0.35847 \\
\hline & $\mathbf{p}$ & 0.0311 & 0.0001 & $\mathrm{~N} / \mathrm{E}$ & 0.4298 & 0.4633 \\
\hline & $\mathbf{n}$ & 7 & 7 & 7 & 2 & 7 \\
\hline \multirow[t]{3}{*}{ Total N } & $\mathbf{r}$ & -1 & -1 & -1 & 1 & 1 \\
\hline & $\mathbf{p}$ & $\mathrm{N} / \mathrm{E}$ & $\mathrm{N} / \mathrm{E}$ & $\mathrm{N} / \mathrm{E}$ & $\mathrm{N} / \mathrm{E}$ & $\mathrm{N} / \mathrm{E}$ \\
\hline & $\mathbf{n}$ & 2 & 2 & 2 & 2 & 2 \\
\hline \multirow[t]{3}{*}{ Nodules } & $\mathbf{r}$ & 0.27056 & -0.26672 & -0.35847 & 1 & 1 \\
\hline & $\mathbf{p}$ & 0.5573 & 0.5631 & 0.4298 & $\mathrm{~N} / \mathrm{E}$ & 0.0002 \\
\hline & $\mathbf{n}$ & 7 & 7 & 7 & 2 & 7 \\
\hline
\end{tabular}




\begin{tabular}{lcccccc} 
Harvest 1- No-salinity & Tephrosia angustissima & & & \\
e & & $\begin{array}{c}\text { Dry Shoot } \\
\text { Weight }\end{array}$ & $\begin{array}{c}\text { Dry Root } \\
\text { Weight }\end{array}$ & Growth & Total N & Nodules \\
\hline Dry Shoot Weight & $\mathbf{r}$ & 1 & 0.92577 & 0.48651 & 0.39756 & 0.99241 \\
& $\mathbf{p}$ & 0.0028 & 0.2682 & 0.7397 & $<.0001$ & $<.0001$ \\
Dry Root Weight & $\mathbf{n}$ & 7 & 7 & 7 & 3 & 7 \\
& $\mathbf{r}$ & 0.92577 & 1 & 0.27903 & 0.67482 & 0.90494 \\
& $\mathbf{p}$ & 0.0028 & 0.5445 & 0.5284 & 0.0051 & 0.0051 \\
Growth & $\mathbf{n}$ & 7 & 7 & 7 & 3 & 7 \\
& $\mathbf{r}$ & 0.48651 & 0.27903 & 1 & -0.77806 & 0.4256 \\
Total N & $\mathbf{p}$ & 0.2682 & 0.5445 & 0.4324 & 0.3411 & 0.3411 \\
& $\mathbf{n}$ & 7 & 7 & 7 & 3 & 7 \\
& $\mathbf{r}$ & 0.39756 & 0.67482 & -0.77806 & 1 & 0.43351 \\
Nodules & $\mathbf{p}$ & 0.7397 & 0.5284 & 0.4324 & 0.7146 & 0.7146 \\
& $\mathbf{n}$ & 3 & 3 & 3 & 3 & 3 \\
& $\mathbf{r}$ & 0.99241 & 0.90494 & 0.4256 & 0.43351 & 1 \\
\hline & $\mathbf{p}$ & $<.0001$ & 0.0051 & 0.3411 & 0.7146 & $<.0001$ \\
\hline
\end{tabular}

Harvest 1- Salinity Tephrosia angustissima

\begin{tabular}{lcccccc}
\hline $\mathbf{f}$ & & $\begin{array}{c}\text { Dry Shoot } \\
\text { Weight }\end{array}$ & $\begin{array}{c}\text { Dry Root } \\
\text { Weight }\end{array}$ & Growth & Total N & Nodules \\
\hline Dry Shoot Weight & $\mathbf{r}$ & $\mathrm{N} / \mathrm{E}$ & $\mathrm{N} / \mathrm{E}$ & $\mathrm{N} / \mathrm{E}$ & $\mathrm{N} / \mathrm{E}$ & $\mathrm{N} / \mathrm{E}$ \\
& $\mathbf{p}$ & $\mathrm{N} / \mathrm{E}$ & $\mathrm{N} / \mathrm{E}$ & $\mathrm{N} / \mathrm{E}$ & $\mathrm{N} / \mathrm{E}$ & $\mathrm{N} / \mathrm{E}$ \\
\multirow{3}{*}{ Dry Root Weight } & $\mathbf{n}$ & $\mathrm{N} / \mathrm{E}$ & $\mathrm{N} / \mathrm{E}$ & $\mathrm{N} / \mathrm{E}$ & $\mathrm{N} / \mathrm{E}$ & $\mathrm{N} / \mathrm{E}$ \\
& $\mathbf{r}$ & $\mathrm{N} / \mathrm{E}$ & $\mathrm{N} / \mathrm{E}$ & $\mathrm{N} / \mathrm{E}$ & $\mathrm{N} / \mathrm{E}$ & $\mathrm{N} / \mathrm{E}$ \\
& $\mathbf{p}$ & $\mathrm{N} / \mathrm{E}$ & $\mathrm{N} / \mathrm{E}$ & $\mathrm{N} / \mathrm{E}$ & $\mathrm{N} / \mathrm{E}$ & $\mathrm{N} / \mathrm{E}$ \\
Growth & $\mathbf{n}$ & $\mathrm{N} / \mathrm{E}$ & $\mathrm{N} / \mathrm{E}$ & $\mathrm{N} / \mathrm{E}$ & $\mathrm{N} / \mathrm{E}$ & $\mathrm{N} / \mathrm{E}$ \\
& $\mathbf{r}$ & $\mathrm{N} / \mathrm{E}$ & $\mathrm{N} / \mathrm{E}$ & $\mathrm{N} / \mathrm{E}$ & $\mathrm{N} / \mathrm{E}$ & $\mathrm{N} / \mathrm{E}$ \\
& $\mathbf{p}$ & $\mathrm{N} / \mathrm{E}$ & $\mathrm{N} / \mathrm{E}$ & $\mathrm{N} / \mathrm{E}$ & $\mathrm{N} / \mathrm{E}$ & $\mathrm{N} / \mathrm{E}$ \\
Total N & $\mathbf{n}$ & $\mathrm{N} / \mathrm{E}$ & $\mathrm{N} / \mathrm{E}$ & $\mathrm{N} / \mathrm{E}$ & $\mathrm{N} / \mathrm{E}$ & $\mathrm{N} / \mathrm{E}$ \\
& $\mathbf{r}$ & $\mathrm{N} / \mathrm{E}$ & $\mathrm{N} / \mathrm{E}$ & $\mathrm{N} / \mathrm{E}$ & $\mathrm{N} / \mathrm{E}$ & $\mathrm{N} / \mathrm{E}$ \\
& $\mathbf{p}$ & $\mathrm{N} / \mathrm{E}$ & $\mathrm{N} / \mathrm{E}$ & $\mathrm{N} / \mathrm{E}$ & $\mathrm{N} / \mathrm{E}$ & $\mathrm{N} / \mathrm{E}$ \\
Nodules & $\mathbf{n}$ & $\mathrm{N} / \mathrm{E}$ & $\mathrm{N} / \mathrm{E}$ & $\mathrm{N} / \mathrm{E}$ & $\mathrm{N} / \mathrm{E}$ & $\mathrm{N} / \mathrm{E}$ \\
& $\mathbf{r}$ & $\mathrm{N} / \mathrm{E}$ & $\mathrm{N} / \mathrm{E}$ & $\mathrm{N} / \mathrm{E}$ & $\mathrm{N} / \mathrm{E}$ & $\mathrm{N} / \mathrm{E}$ \\
& $\mathbf{p}$ & $\mathrm{N} / \mathrm{E}$ & $\mathrm{N} / \mathrm{E}$ & $\mathrm{N} / \mathrm{E}$ & $\mathrm{N} / \mathrm{E}$ & $\mathrm{N} / \mathrm{E}$ \\
& $\mathbf{n}$ & $\mathrm{N} / \mathrm{E}$ & $\mathrm{N} / \mathrm{E}$ & $\mathrm{N} / \mathrm{E}$ & $\mathrm{N} / \mathrm{E}$ & $\mathrm{N} / \mathrm{E}$ \\
\hline
\end{tabular}




\begin{tabular}{lcccccc}
\multicolumn{1}{l}{ Harvest 1- No-salinity Abrus precatorious } & & & \\
\hline g & & $\begin{array}{c}\text { Dry Shoot } \\
\text { Weight }\end{array}$ & $\begin{array}{c}\text { Dry Root } \\
\text { Weight }\end{array}$ & Growth & Total N & Nodules \\
\hline Dry Shoot Weight & $\mathbf{r}$ & 1 & 0.90941 & 0.29343 & 0.49023 & 0.57631 \\
& $\mathbf{p}$ & $<.0001$ & 0.2885 & 0.1803 & 0.0245 & 0.0031 \\
Dry Root Weight & $\mathbf{n}$ & 15 & 15 & 15 & 9 & 15 \\
& $\mathbf{r}$ & 0.90941 & 1 & 0.45629 & 0.34217 & 0.48093 \\
& $\mathbf{p}$ & $<.0001$ & 0.0873 & 0.3674 & 0.0696 & $<.0001$ \\
Growth & $\mathbf{n}$ & 15 & 15 & 15 & 9 & 15 \\
& $\mathbf{r}$ & 0.29343 & 0.45629 & 1 & 0.15972 & 0.31508 \\
Total N & $\mathbf{p}$ & 0.2885 & 0.0873 & 0.6815 & 0.2527 & 0.0136 \\
& $\mathbf{n}$ & 15 & 15 & 15 & 9 & 15 \\
& $\mathbf{r}$ & 0.49023 & 0.34217 & 0.15972 & 1 & 0.57575 \\
Nodules & $\mathbf{p}$ & 0.1803 & 0.3674 & 0.6815 & 0.1047 & 0.4025 \\
& $\mathbf{n}$ & 9 & 9 & 9 & 9 & 9 \\
& $\mathbf{r}$ & 0.57631 & 0.48093 & 0.31508 & 0.57575 & 1 \\
& $\mathbf{p}$ & 0.0245 & 0.0696 & 0.2527 & 0.1047 & 0.0062 \\
& $\mathbf{n}$ & 15 & 15 & 15 & 9 & 15 \\
\hline
\end{tabular}

Harvest 1- Salinity Abrus precatorious

\begin{tabular}{lcccccc}
\hline h & Dry Shoot & $\begin{array}{c}\text { Dry Root } \\
\text { Weight }\end{array}$ & Growth & Total N & Nodules \\
\hline Dry Shoot Weight & $\mathbf{r}$ & 1 & 0.70227 & 0.1813 & -0.22461 & 0.69159 \\
& $\mathbf{p}$ & 0.0109 & 0.5728 & 0.6688 & 0.0127 & 0.1429 \\
Dry Root Weight & $\mathbf{n}$ & 12 & 12 & 12 & 6 & 12 \\
& $\mathbf{r}$ & 0.70227 & 1 & 0.00321 & -0.51539 & 0.33733 \\
& $\mathbf{p}$ & 0.0109 & 0.9921 & 0.2954 & 0.2836 & 0.6971 \\
Growth & $\mathbf{n}$ & 12 & 12 & 12 & 6 & 12 \\
& $\mathbf{r}$ & 0.1813 & 0.00321 & 1 & 0.48481 & 0.53055 \\
Total N & $\mathbf{p}$ & 0.5728 & 0.9921 & 0.3298 & 0.076 & 0.5279 \\
& $\mathbf{n}$ & 12 & 12 & 12 & 6 & 12 \\
& $\mathbf{r}$ & -0.22461 & -0.51539 & 0.48481 & 1 & 0.36091 \\
Nodules & $\mathbf{p}$ & 0.6688 & 0.2954 & 0.3298 & 0.4821 & 0.7754 \\
& $\mathbf{n}$ & 6 & 6 & 6 & 6 & 6 \\
& $\mathbf{r}$ & 0.69159 & 0.33733 & 0.53055 & 0.36091 & 1 \\
& $\mathbf{p}$ & 0.0127 & 0.2836 & 0.076 & 0.4821 & 0.1118 \\
\hline
\end{tabular}


Table 6. Correlation among plant performance measurements and nodulation, by plant host species in harvest 2. Pearson's r, P-value, and the number of samples (n) are shown for each character combination. N/E non estimable values given the low sample size.

\begin{tabular}{|c|c|c|c|c|c|c|}
\hline $\mathbf{a}$ & & $\begin{array}{c}\text { Dry Shoot } \\
\text { Weight }\end{array}$ & $\begin{array}{c}\text { Dry Root } \\
\text { Weight }\end{array}$ & Growth & Total $\mathbf{N}$ & Nodules \\
\hline \multirow[t]{3}{*}{ Dry Shoot Weight } & $\mathbf{r}$ & 1 & 0.77211 & 0.61223 & 0.49087 & 0.72991 \\
\hline & $\mathbf{p}$ & 0.0054 & 0.0453 & 0.6734 & 0.0108 & 0.148 \\
\hline & $\mathbf{n}$ & 11 & 11 & 11 & 3 & 11 \\
\hline \multirow[t]{3}{*}{ Dry Root Weight } & $\mathbf{r}$ & 0.77211 & 1 & 0.09629 & -0.89646 & 0.8705 \\
\hline & $\mathbf{p}$ & 0.0054 & 0.7782 & 0.2923 & 0.0005 & 0.079 \\
\hline & $\mathbf{n}$ & 11 & 11 & 11 & 3 & 11 \\
\hline \multirow[t]{3}{*}{ Growth } & $\mathbf{r}$ & 0.61223 & 0.09629 & 1 & 0.62027 & 0.18591 \\
\hline & $\mathbf{p}$ & 0.0453 & 0.7782 & 0.574 & 0.5842 & 0.8416 \\
\hline & $\mathbf{n}$ & 11 & 11 & 11 & 3 & 11 \\
\hline \multirow[t]{3}{*}{ Total N } & $\mathbf{r}$ & 0.49087 & -0.89646 & 0.62027 & 1 & -0.5252 \\
\hline & $\mathbf{p}$ & 0.6734 & 0.2923 & 0.574 & 0.648 & 0.7612 \\
\hline & $\mathbf{n}$ & 3 & 3 & 3 & 3 & 3 \\
\hline \multirow[t]{3}{*}{ Nodules } & $\mathbf{r}$ & 0.72991 & 0.8705 & 0.18591 & -0.5252 & 1 \\
\hline & $\mathbf{p}$ & 0.0108 & 0.0005 & 0.5842 & 0.648 & 0.0032 \\
\hline & $\mathbf{n}$ & 11 & 11 & 11 & 3 & 11 \\
\hline
\end{tabular}

\begin{tabular}{|c|c|c|c|c|c|c|}
\hline b & & $\begin{array}{c}\text { Dry Shoot } \\
\text { Weight }\end{array}$ & $\begin{array}{c}\text { Dry Root } \\
\text { Weight }\end{array}$ & Growth & Total N & Nodules \\
\hline \multirow[t]{3}{*}{ Dry Shoot Weight } & $\mathbf{r}$ & 1 & 0.97329 & 0.66378 & -0.04352 & 0.72627 \\
\hline & $\mathbf{p}$ & $<.0001$ & 0.0186 & 0.9262 & 0.0075 & 0.0494 \\
\hline & $\mathbf{n}$ & 12 & 12 & 12 & 7 & 12 \\
\hline \multirow[t]{3}{*}{ Dry Root Weight } & $\mathbf{r}$ & 0.97329 & 1 & 0.72635 & 0.04949 & 0.73308 \\
\hline & $\mathbf{p}$ & $<.0001$ & 0.0075 & 0.9161 & 0.0067 & 0.0373 \\
\hline & $\mathbf{n}$ & 12 & 12 & 12 & 7 & 12 \\
\hline \multirow[t]{3}{*}{ Growth } & $\mathbf{r}$ & 0.66378 & 0.72635 & 1 & -0.63516 & 0.38893 \\
\hline & $\mathbf{p}$ & 0.0186 & 0.0075 & 0.1253 & 0.2115 & 0.1196 \\
\hline & $\mathbf{n}$ & 12 & 12 & 12 & 7 & 12 \\
\hline \multirow[t]{3}{*}{ Total $\mathbf{N}$} & $\mathbf{r}$ & -0.04352 & 0.04949 & -0.63516 & 1 & -0.13647 \\
\hline & $\mathbf{p}$ & 0.9262 & 0.9161 & 0.1253 & 0.7705 & 0.2403 \\
\hline & $\mathbf{n}$ & 7 & 7 & 7 & 7 & 7 \\
\hline \multirow[t]{3}{*}{ Nodules } & $\mathbf{r}$ & 0.72627 & 0.73308 & 0.38893 & -0.13647 & 1 \\
\hline & $\mathbf{p}$ & 0.0075 & 0.0067 & 0.2115 & 0.7705 & 0.9368 \\
\hline & $\mathbf{n}$ & 12 & 12 & 12 & 7 & 12 \\
\hline
\end{tabular}




\begin{tabular}{|c|c|c|c|c|c|c|}
\hline c & & $\begin{array}{c}\text { Dry Shoot } \\
\text { Weight }\end{array}$ & $\begin{array}{c}\text { Dry Root } \\
\text { Weight }\end{array}$ & Growth & Total N & Nodules \\
\hline \multirow[t]{3}{*}{ Dry Shoot Weight } & $\mathbf{r}$ & 1 & 0.97209 & 0.7975 & $\mathrm{~N} / \mathrm{E}$ & 0.64202 \\
\hline & $\mathbf{p}$ & 0.0012 & 0.0574 & $\mathrm{~N} / \mathrm{E}$ & 0.1693 & 0.0029 \\
\hline & $\mathbf{n}$ & 6 & 6 & 6 & 0 & 6 \\
\hline \multirow[t]{3}{*}{ Dry Root Weight } & $\mathbf{r}$ & 0.97209 & 1 & 0.66705 & $\mathrm{~N} / \mathrm{E}$ & 0.62504 \\
\hline & $\mathbf{p}$ & 0.0012 & 0.1478 & $\mathrm{~N} / \mathrm{E}$ & 0.1845 & 0.0024 \\
\hline & $\mathbf{n}$ & 6 & 6 & 6 & 0 & 6 \\
\hline \multirow[t]{3}{*}{ Growth } & $\mathbf{r}$ & 0.7975 & 0.66705 & 1 & $\mathrm{~N} / \mathrm{E}$ & 0.67688 \\
\hline & $\mathbf{p}$ & 0.0574 & 0.1478 & $\mathrm{~N} / \mathrm{E}$ & 0.1397 & 0.0719 \\
\hline & $\mathbf{n}$ & 6 & 6 & 6 & 0 & 6 \\
\hline \multirow[t]{3}{*}{ Total N } & $\mathbf{r}$ & $\mathrm{N} / \mathrm{E}$ & $\mathrm{N} / \mathrm{E}$ & $\mathrm{N} / \mathrm{E}$ & $\mathrm{N} / \mathrm{E}$ & $\mathrm{N} / \mathrm{E}$ \\
\hline & $\mathbf{p}$ & $\mathrm{N} / \mathrm{E}$ & $\mathrm{N} / \mathrm{E}$ & $\mathrm{N} / \mathrm{E}$ & $\mathrm{N} / \mathrm{E}$ & $\mathrm{N} / \mathrm{E}$ \\
\hline & $\mathbf{n}$ & 0 & 0 & 0 & 0 & 0 \\
\hline \multirow[t]{3}{*}{ Nodules } & $\mathbf{r}$ & 0.64202 & 0.62504 & 0.67688 & $\mathrm{~N} / \mathrm{E}$ & 1 \\
\hline & $\mathbf{p}$ & 0.1693 & 0.1845 & 0.1397 & $\mathrm{~N} / \mathrm{E}$ & 0.0642 \\
\hline & $\mathbf{n}$ & 6 & 6 & 6 & 0 & 6 \\
\hline
\end{tabular}

Harvest 2- Salinity Chamaecrista fasciculata

\begin{tabular}{lcccccc}
\hline d & Dry Shoot & $\begin{array}{c}\text { Dry Root } \\
\text { Weight }\end{array}$ & Growth & Total N & Nodules \\
\hline Dry Shoot Weight & $\mathbf{r}$ & 1 & 0.89283 & 0.64181 & $\mathrm{~N} / \mathrm{E}$ & 0.76044 \\
& $\mathbf{p}$ & 0.0005 & 0.0624 & $\mathrm{~N} / \mathrm{E}$ & 0.0107 & 0.0047 \\
Dry Root Weight & $\mathbf{n}$ & 10 & 10 & 9 & 1 & 10 \\
& $\mathbf{r}$ & 0.89283 & 1 & 0.62222 & $\mathrm{~N} / \mathrm{E}$ & 0.62524 \\
& $\mathbf{p}$ & 0.0005 & 0.0736 & $\mathrm{~N} / \mathrm{E}$ & 0.0532 & $<.0001$ \\
Growth & $\mathbf{n}$ & 10 & 10 & 9 & 1 & 10 \\
& $\mathbf{r}$ & 0.64181 & 0.62222 & 1 & $\mathrm{~N} / \mathrm{E}$ & 0.84184 \\
& $\mathbf{p}$ & 0.0624 & 0.0736 & $\mathrm{~N} / \mathrm{E}$ & 0.0044 & 0.0286 \\
Total N & $\mathbf{n}$ & 9 & 9 & 9 & 1 & 9 \\
& $\mathbf{r}$ & $\mathrm{N} / \mathrm{E}$ & $\mathrm{N} / \mathrm{E}$ & $\mathrm{N} / \mathrm{E}$ & $\mathrm{N} / \mathrm{E}$ & $\mathrm{N} / \mathrm{E}$ \\
& $\mathbf{p}$ & $\mathrm{N} / \mathrm{E}$ & $\mathrm{N} / \mathrm{E}$ & $\mathrm{N} / \mathrm{E}$ & $\mathrm{N} / \mathrm{E}$ & $\mathrm{N} / \mathrm{E}$ \\
Nodules & $\mathbf{n}$ & 1 & 1 & 1 & 1 & 1 \\
& $\mathbf{r}$ & 0.76044 & 0.62524 & 0.84184 & $\mathrm{~N} / \mathrm{E}$ & 1 \\
& $\mathbf{p}$ & 0.0107 & 0.0532 & 0.0044 & $\mathrm{~N} / \mathrm{E}$ & 0.0245 \\
& $\mathbf{n}$ & 10 & 10 & 9 & 1 & 10 \\
\hline
\end{tabular}




\begin{tabular}{|c|c|c|c|c|c|c|}
\hline $\mathbf{e}$ & & Dry Shoot Weight & $\begin{array}{c}\text { Dry Root } \\
\text { Weight }\end{array}$ & Growth & Total N & Nodules \\
\hline \multirow[t]{3}{*}{ Dry Shoot Weight } & $\mathbf{r}$ & 1 & 0.943 & -0.98595 & $\mathrm{~N} / \mathrm{E}$ & $\mathrm{N} / \mathrm{E}$ \\
\hline & $\mathbf{p}$ & 0.216 & 0.1069 & $\mathrm{~N} / \mathrm{E}$ & $\mathrm{N} / \mathrm{E}$ & $\mathrm{N} / \mathrm{E}$ \\
\hline & $\mathbf{n}$ & 3 & 3 & 3 & 0 & 3 \\
\hline \multirow[t]{3}{*}{ Dry Root Weight } & $\mathbf{r}$ & 0.943 & 1 & -0.98535 & $\mathrm{~N} / \mathrm{E}$ & $\mathrm{N} / \mathrm{E}$ \\
\hline & $\mathbf{p}$ & 0.216 & 0.1091 & $\mathrm{~N} / \mathrm{E}$ & $\mathrm{N} / \mathrm{E}$ & $\mathrm{N} / \mathrm{E}$ \\
\hline & $\mathbf{n}$ & 3 & 3 & 3 & 0 & 3 \\
\hline \multirow[t]{3}{*}{ Growth } & $\mathbf{r}$ & -0.98595 & -0.98535 & 1 & $\mathrm{~N} / \mathrm{E}$ & $\mathrm{N} / \mathrm{E}$ \\
\hline & $\mathbf{p}$ & 0.1069 & 0.1091 & $\mathrm{~N} / \mathrm{E}$ & $\mathrm{N} / \mathrm{E}$ & $\mathrm{N} / \mathrm{E}$ \\
\hline & $\mathbf{n}$ & 3 & 3 & 3 & 0 & 3 \\
\hline \multirow[t]{3}{*}{ Total N } & $\mathbf{r}$ & $\mathrm{N} / \mathrm{E}$ & $\mathrm{N} / \mathrm{E}$ & $\mathrm{N} / \mathrm{E}$ & $\mathrm{N} / \mathrm{E}$ & $\mathrm{N} / \mathrm{E}$ \\
\hline & $\mathbf{p}$ & $\mathrm{N} / \mathrm{E}$ & $\mathrm{N} / \mathrm{E}$ & $\mathrm{N} / \mathrm{E}$ & $\mathrm{N} / \mathrm{E}$ & $\mathrm{N} / \mathrm{E}$ \\
\hline & $\mathbf{n}$ & 0 & 0 & 0 & 0 & 0 \\
\hline \multirow[t]{3}{*}{ Nodules } & $\mathbf{r}$ & $\mathrm{N} / \mathrm{E}$ & $\mathrm{N} / \mathrm{E}$ & $\mathrm{N} / \mathrm{E}$ & $\mathrm{N} / \mathrm{E}$ & $\mathrm{N} / \mathrm{E}$ \\
\hline & $\mathbf{p}$ & $\mathrm{N} / \mathrm{E}$ & $\mathrm{N} / \mathrm{E}$ & $\mathrm{N} / \mathrm{E}$ & $\mathrm{N} / \mathrm{E}$ & $\mathrm{N} / \mathrm{E}$ \\
\hline & $\mathbf{n}$ & 3 & 3 & 3 & 0 & 3 \\
\hline
\end{tabular}

Harvest 2- Salinity Tephrosia angustissima

\begin{tabular}{lcccccc}
\hline $\mathbf{f}$ & Dry Shoot Weight & $\begin{array}{c}\text { Dry Root } \\
\text { Weight }\end{array}$ & Growth & Total N & Nodules \\
\hline Dry Shoot Weight & $\mathbf{r}$ & $\mathrm{N} / \mathrm{E}$ & $\mathrm{N} / \mathrm{E}$ & $\mathrm{N} / \mathrm{E}$ & $\mathrm{N} / \mathrm{E}$ & $\mathrm{N} / \mathrm{E}$ \\
& $\mathbf{p}$ & $\mathrm{N} / \mathrm{E}$ & $\mathrm{N} / \mathrm{E}$ & $\mathrm{N} / \mathrm{E}$ & $\mathrm{N} / \mathrm{E}$ & $\mathrm{N} / \mathrm{E}$ \\
\multirow{3}{*}{ Dry Root Weight } & $\mathbf{n}$ & $\mathrm{N} / \mathrm{E}$ & $\mathrm{N} / \mathrm{E}$ & $\mathrm{N} / \mathrm{E}$ & $\mathrm{N} / \mathrm{E}$ & $\mathrm{N} / \mathrm{E}$ \\
& $\mathbf{r}$ & $\mathrm{N} / \mathrm{E}$ & $\mathrm{N} / \mathrm{E}$ & $\mathrm{N} / \mathrm{E}$ & $\mathrm{N} / \mathrm{E}$ & $\mathrm{N} / \mathrm{E}$ \\
& $\mathbf{p}$ & $\mathrm{N} / \mathrm{E}$ & $\mathrm{N} / \mathrm{E}$ & $\mathrm{N} / \mathrm{E}$ & $\mathrm{N} / \mathrm{E}$ & $\mathrm{N} / \mathrm{E}$ \\
Growth & $\mathbf{n}$ & $\mathrm{N} / \mathrm{E}$ & $\mathrm{N} / \mathrm{E}$ & $\mathrm{N} / \mathrm{E}$ & $\mathrm{N} / \mathrm{E}$ & $\mathrm{N} / \mathrm{E}$ \\
& $\mathbf{r}$ & $\mathrm{N} / \mathrm{E}$ & $\mathrm{N} / \mathrm{E}$ & $\mathrm{N} / \mathrm{E}$ & $\mathrm{N} / \mathrm{E}$ & $\mathrm{N} / \mathrm{E}$ \\
& $\mathbf{p}$ & $\mathrm{N} / \mathrm{E}$ & $\mathrm{N} / \mathrm{E}$ & $\mathrm{N} / \mathrm{E}$ & $\mathrm{N} / \mathrm{E}$ & $\mathrm{N} / \mathrm{E}$ \\
Total N & $\mathbf{n}$ & $\mathrm{N} / \mathrm{E}$ & $\mathrm{N} / \mathrm{E}$ & $\mathrm{N} / \mathrm{E}$ & $\mathrm{N} / \mathrm{E}$ & $\mathrm{N} / \mathrm{E}$ \\
& $\mathbf{r}$ & $\mathrm{N} / \mathrm{E}$ & $\mathrm{N} / \mathrm{E}$ & $\mathrm{N} / \mathrm{E}$ & $\mathrm{N} / \mathrm{E}$ & $\mathrm{N} / \mathrm{E}$ \\
& $\mathbf{p}$ & $\mathrm{N} / \mathrm{E}$ & $\mathrm{N} / \mathrm{E}$ & $\mathrm{N} / \mathrm{E}$ & $\mathrm{N} / \mathrm{E}$ & $\mathrm{N} / \mathrm{E}$ \\
Nodules & $\mathbf{n}$ & $\mathrm{N} / \mathrm{E}$ & $\mathrm{N} / \mathrm{E}$ & $\mathrm{N} / \mathrm{E}$ & $\mathrm{N} / \mathrm{E}$ & $\mathrm{N} / \mathrm{E}$ \\
& $\mathbf{r}$ & $\mathrm{N} / \mathrm{E}$ & $\mathrm{N} / \mathrm{E}$ & $\mathrm{N} / \mathrm{E}$ & $\mathrm{N} / \mathrm{E}$ & $\mathrm{N} / \mathrm{E}$ \\
& $\mathbf{p}$ & $\mathrm{N} / \mathrm{E}$ & $\mathrm{N} / \mathrm{E}$ & $\mathrm{N} / \mathrm{E}$ & $\mathrm{N} / \mathrm{E}$ & $\mathrm{N} / \mathrm{E}$ \\
& $\mathbf{n}$ & $\mathrm{N} / \mathrm{E}$ & $\mathrm{N} / \mathrm{E}$ & $\mathrm{N} / \mathrm{E}$ & $\mathrm{N} / \mathrm{E}$ \\
\hline
\end{tabular}




\begin{tabular}{lcccccc} 
Harvest 2- No-salinity & Abrus precatorious \\
\hline g & Dry Shoot & Weight & $\begin{array}{c}\text { Dry Root } \\
\text { Weight }\end{array}$ & Growth & Total N & Nodules \\
\hline Dry Shoot Weight & $\mathbf{r}$ & 1 & 0.95634 & 0.2391 & -1 & 0.90116 \\
& $\mathbf{p}$ & $<.0001$ & 0.3554 & $\mathrm{~N} / \mathrm{E}$ & $<.0001$ & 0.0023 \\
Dry Root Weight & $\mathbf{n}$ & 17 & 17 & 17 & 2 & 17 \\
& $\mathbf{r}$ & 0.95634 & 1 & 0.15325 & -1 & 0.88677 \\
& $\mathbf{p}$ & $<.0001$ & 0.557 & $\mathrm{~N} / \mathrm{E}$ & $<.0001$ & 0.0101 \\
Growth & $\mathbf{n}$ & 17 & 17 & 17 & 2 & 17 \\
& $\mathbf{r}$ & 0.2391 & 0.15325 & 1 & 1 & 0.51144 \\
Total N & $\mathbf{p}$ & 0.3554 & 0.557 & $\mathrm{~N} / \mathrm{E}$ & 0.0359 & 0.0052 \\
& $\mathbf{n}$ & 17 & 17 & 17 & 2 & 17 \\
& $\mathbf{r}$ & -1 & -1 & 1 & 1 & 1 \\
Nodules & $\mathbf{p}$ & $\mathrm{N} / \mathrm{E}$ & $\mathrm{N} / \mathrm{E}$ & $\mathrm{N} / \mathrm{E}$ & $\mathrm{N} / \mathrm{E}$ & $\mathrm{N} / \mathrm{E}$ \\
& $\mathbf{n}$ & 2 & 2 & 2 & 2 & 2 \\
& $\mathbf{r}$ & 0.90116 & 0.88677 & 0.51144 & 1 & 1 \\
& $\mathbf{p}$ & $<.0001$ & $<.0001$ & 0.0359 & $\mathrm{~N} / \mathrm{E}$ & $<.0001$
\end{tabular}

Harvest 2- Salinity Abrus precatorious

\begin{tabular}{|c|c|c|c|c|c|c|}
\hline $\mathbf{h}$ & & $\begin{array}{c}\text { Dry Shoot } \\
\text { Weight }\end{array}$ & $\begin{array}{c}\text { Dry Root } \\
\text { Weight }\end{array}$ & Growth & Total N & Nodules \\
\hline \multirow[t]{3}{*}{ Dry Shoot Weight } & $\mathbf{r}$ & 1 & 0.93245 & 0.67946 & $\mathrm{~N} / \mathrm{E}$ & 0.73949 \\
\hline & $\mathbf{p}$ & $<.0001$ & 0.0014 & $\mathrm{~N} / \mathrm{E}$ & 0.0003 & $<.0001$ \\
\hline & $\mathbf{n}$ & 19 & 19 & 19 & 0 & 19 \\
\hline \multirow[t]{3}{*}{ Dry Root Weight } & $\mathbf{r}$ & 0.93245 & 1 & 0.67078 & $\mathrm{~N} / \mathrm{E}$ & 0.65979 \\
\hline & $\mathbf{p}$ & $<.0001$ & 0.0017 & $\mathrm{~N} / \mathrm{E}$ & 0.0021 & $<.0001$ \\
\hline & $\mathbf{n}$ & 19 & 19 & 19 & 0 & 19 \\
\hline \multirow[t]{3}{*}{ Growth } & $\mathbf{r}$ & 0.67946 & 0.67078 & 1 & $\mathrm{~N} / \mathrm{E}$ & 0.6373 \\
\hline & $\mathbf{p}$ & 0.0014 & 0.0017 & $\mathrm{~N} / \mathrm{E}$ & 0.0033 & 0.085 \\
\hline & $\mathbf{n}$ & 19 & 19 & 19 & 0 & 19 \\
\hline \multirow[t]{3}{*}{ Total N } & $\mathbf{r}$ & $\mathrm{N} / \mathrm{E}$ & $\mathrm{N} / \mathrm{E}$ & $\mathrm{N} / \mathrm{E}$ & $\mathrm{N} / \mathrm{E}$ & $\mathrm{N} / \mathrm{E}$ \\
\hline & $\mathbf{p}$ & $\mathrm{N} / \mathrm{E}$ & $\mathrm{N} / \mathrm{E}$ & $\mathrm{N} / \mathrm{E}$ & $\mathrm{N} / \mathrm{E}$ & $\mathrm{N} / \mathrm{E}$ \\
\hline & $\mathbf{n}$ & 0 & 0 & 0 & 0 & 0 \\
\hline \multirow[t]{3}{*}{ Nodules } & $\mathbf{r}$ & 0.73949 & 0.65979 & 0.6373 & $\mathrm{~N} / \mathrm{E}$ & 1 \\
\hline & $\mathbf{p}$ & 0.0003 & 0.0021 & 0.0033 & $\mathrm{~N} / \mathrm{E}$ & 0.004 \\
\hline & $\mathbf{n}$ & 19 & 19 & 19 & 0 & 19 \\
\hline
\end{tabular}




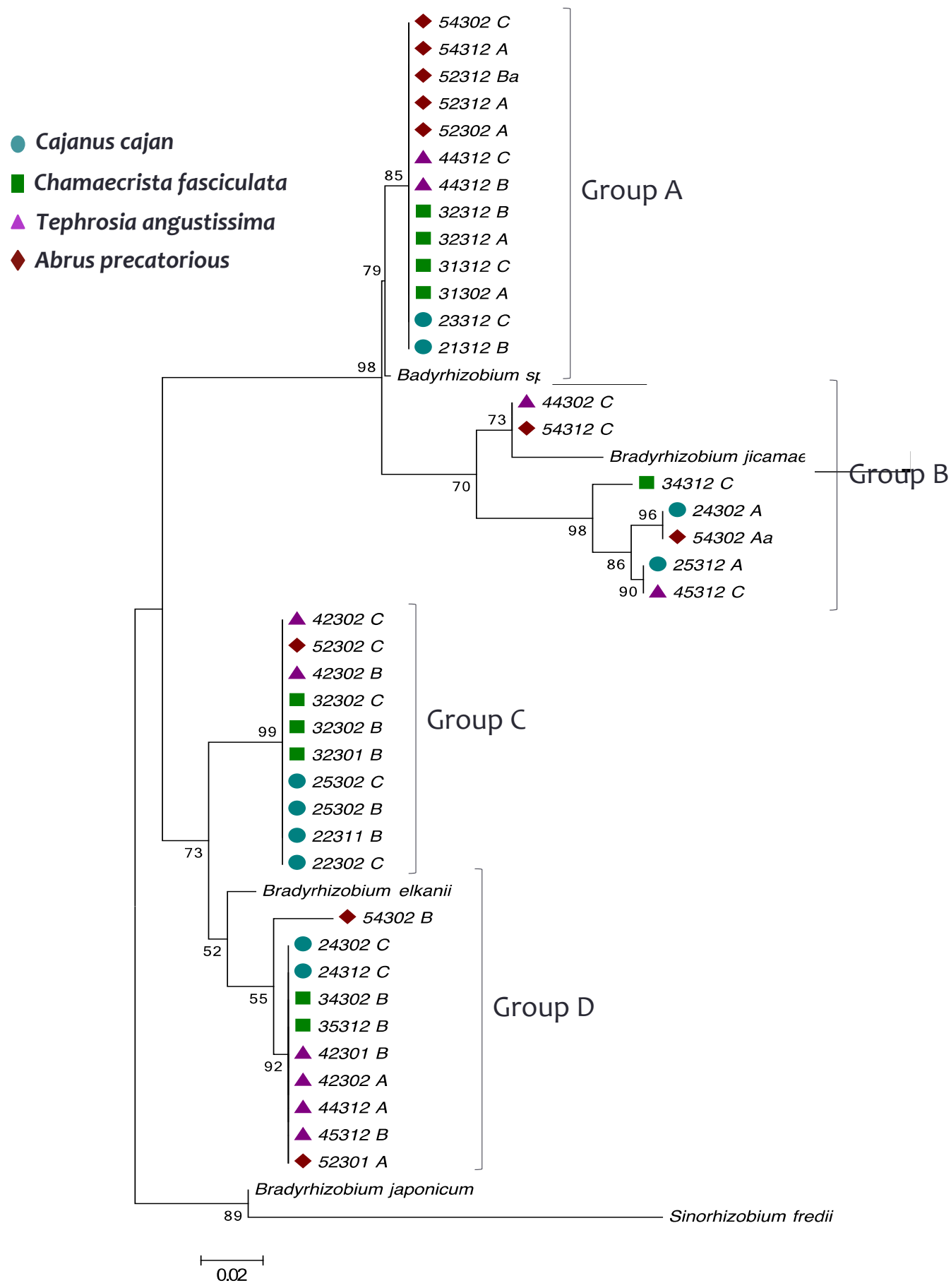

Figure 6. Maximum likelihood tree of nifH sequences showing the phylogenetic relationship between isolated rhizobia from four legume host species and outgroup strains. Bootstrap confidence levels greater than $50 \%$ are indicated at the internodes. 


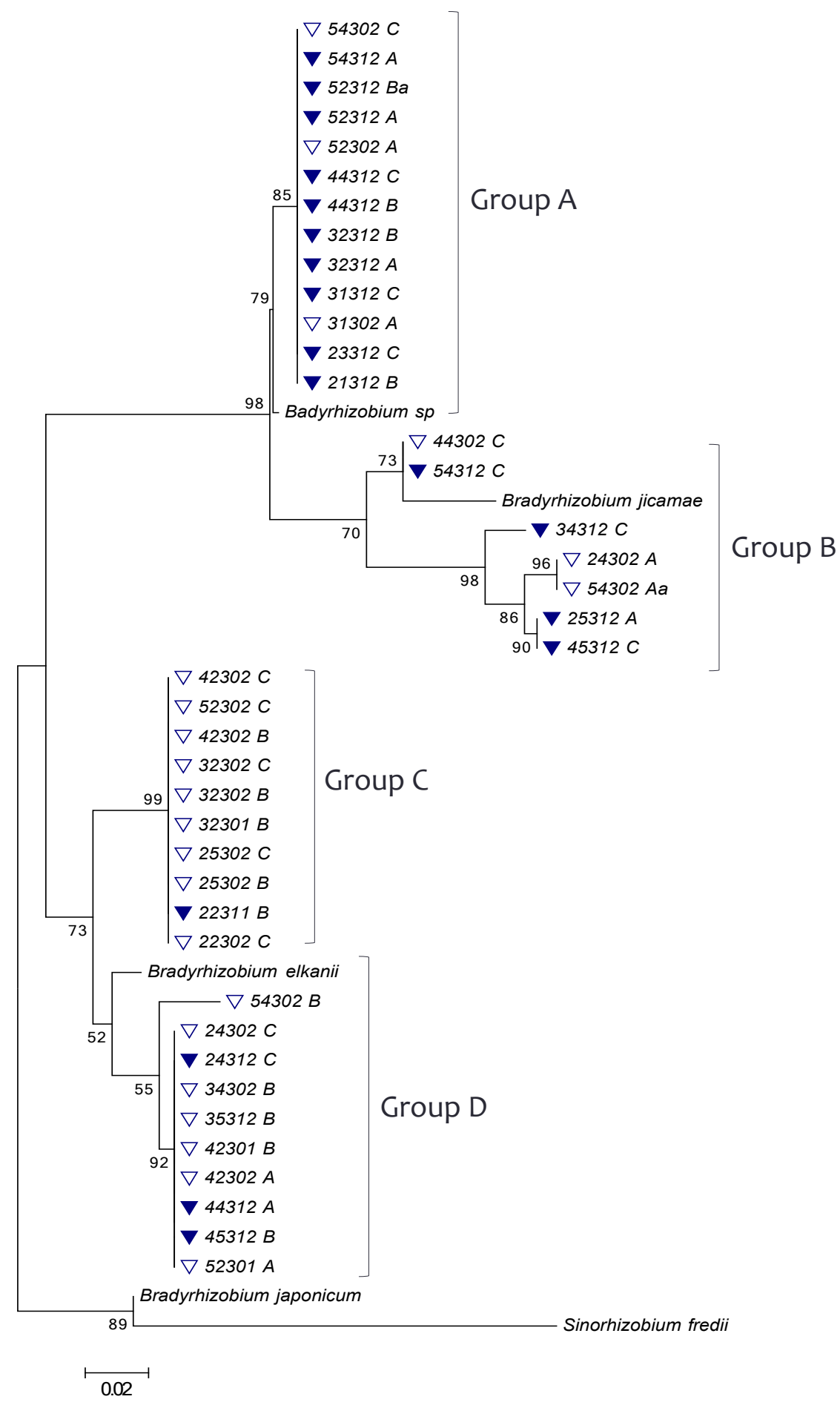

Figure 7. Maximum likelihood tree of nifH sequences showing the phylogenetic relationship between saline $(\boldsymbol{\nabla})$ and non-saline $(\nabla)$ treatment. Bootstrap confidence levels greater than $50 \%$ are indicated at the internodes. 


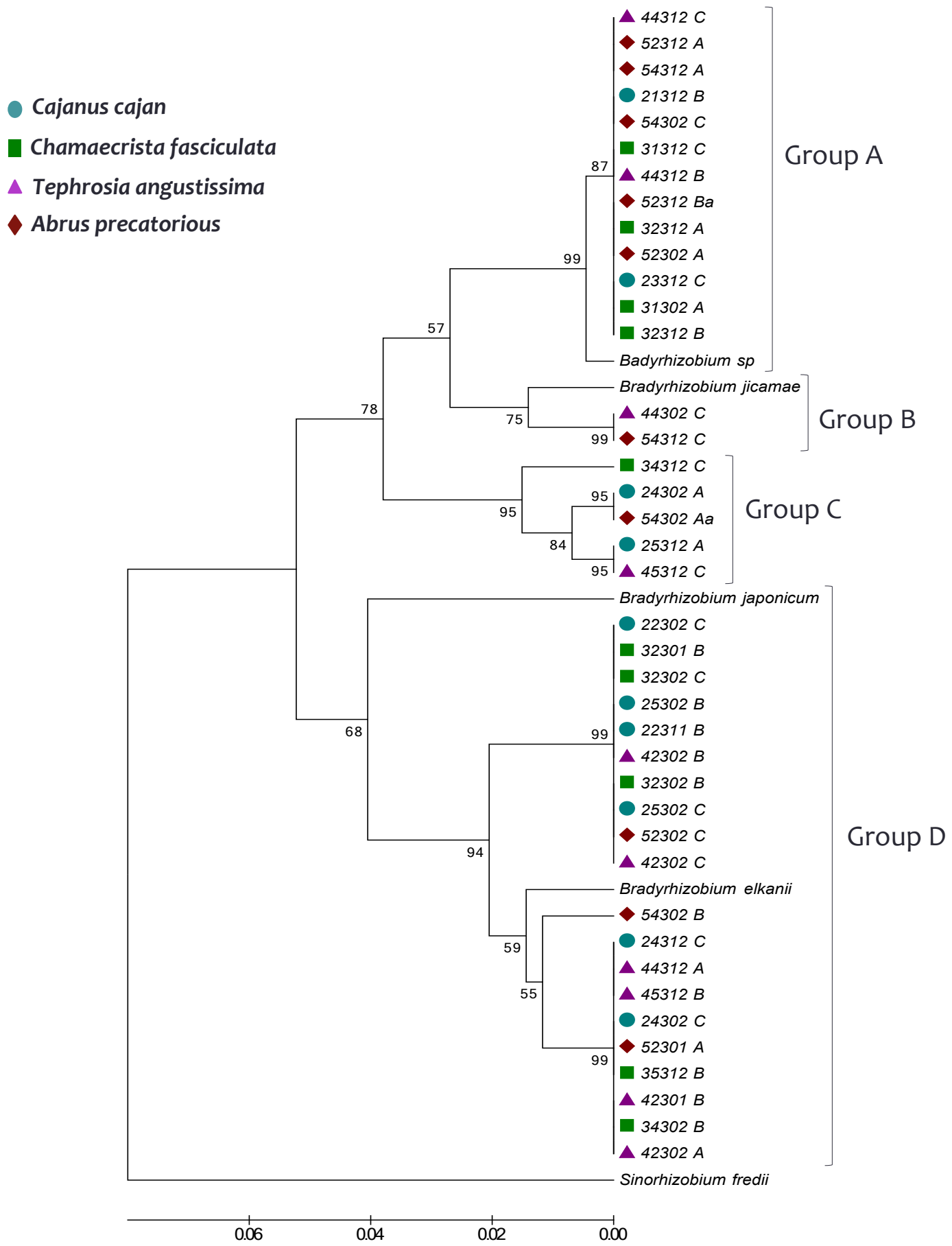

Figure 8. UPGMA tree of nifH sequences showing the phylogenetic relationship between isolated rhizobia from four legume host species and outgroup strains. Bootstrap confidence levels greater than $50 \%$ are indicated at the internodes. 


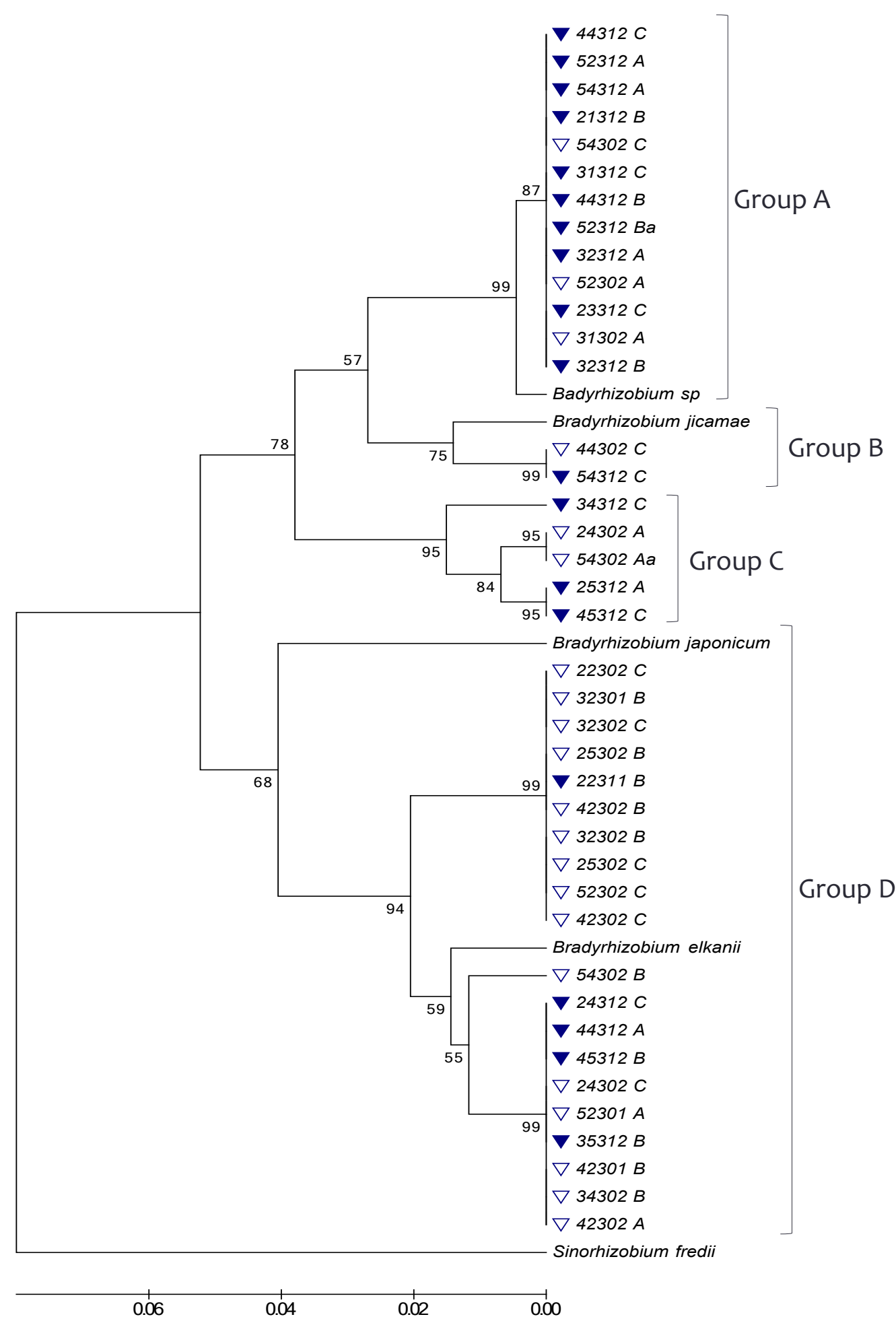

Figure 9. UPGMA tree of nifH sequences showing the phylogenetic relationship between saline $(\boldsymbol{\nabla})$ and non-saline $(\nabla)$ treatment. Bootstrap confidence levels greater than $50 \%$ are indicated at the internodes. 